\title{
Archaic Land Use of Upper Leon Creek Terraces: Archaeological Testing in Northern Bexar County, Texas
}

Cynthia L. Tennis

Center for Archaeological Research

Follow this and additional works at: https://scholarworks.sfasu.edu/ita

Part of the American Material Culture Commons, Archaeological Anthropology Commons, Environmental Studies Commons, Other American Studies Commons, Other Arts and Humanities Commons, Other History of Art, Architecture, and Archaeology Commons, and the United States History Commons

Tell us how this article helped you.

This Article is brought to you for free and open access by the Center for Regional Heritage Research at SFA ScholarWorks. It has been accepted for inclusion in Index of Texas Archaeology: Open Access Gray Literature from the Lone Star State by an authorized editor of SFA ScholarWorks. For more information, please contact cdsscholarworks@sfasu.edu. 


\section{Archaic Land Use of Upper Leon Creek Terraces: Archaeological Testing in Northern Bexar County, Texas}

\section{Creative Commons License}

\section{(c) (1) \&}

This work is licensed under a Creative Commons Attribution-NonCommercial 4.0 International License 


\title{
ARCHAIC LAND USE OF UPPER LEON CREEK TERRACES: ARCHAEOLOGICAL TESTING IN NORTHERN BEXAR COUNTY, TEXAS
}

\author{
Cynthia L. Tennis \\ With contributions by \\ Robert J. Hard, C. Britt Bousman, \\ Lee C. Nordt, and Wulf Gose
}

Robert J. Hard and C. Britt Bousman, co-principal investigators

${ }^{\circ}$ copyright

Center for Archaeological Research

The University of Texas at San Antonio Archaeological Survey Report, No. 234 
The following information is provided in accordance with the General Rules of Practice and Procedure, Chapter 41.11 (Investigative Reports), Texas Antiquities Committee:

1. Type of investigation: Testing.

2. Project name: Leon Creek Terrace Testing

3. County: Bexar

4. Principal investigators: Robert J. Hard and C. Britt Bousman

5. Name and location of sponsoring agency: U.S. Army Corps of Engineers, Fort Worth, Texas.

6. Texas Antiquities Committee Permit No.: n/a

7. Published by the Center for Archaeological Research, The University of Texas at San Antonio, 6900 N. Loop 1604 W., San Antonio, Texas 78249-0658, 1996

A list of publications offered by the Center for Archaeological Research is available. Call (210) 458-4378; write to the Center for Archaeological Research, The University of Texas at San Antonio, 6900 N. Loop 1604 W., San Antonio, Texas 78249-0658; or e-mail to car@lonestar.utsa.edu. 


\begin{abstract}
During a three-week period in March 1995, the Center for Archaeological Research (CAR) of The University of Texas at San Antonio (UTSA) conducted the second phase of archaeological work at 41BX47 under contract with PapeDawson Engineers. This phase of intensive testing was designed to assess the significance of the Early and Middle Archaic deposits identified during the 1994 CAR survey of the 147-acre project area (Tennis and Hard 1995). These investigations were performed to further comply with U.S. Army Corps of Engineers permit requirements.
\end{abstract}

ABSTRACT

Fieldwork consisted of fourteen 1-x-1-m test units, 59 Gradall trenches, and additional geomorphological investigations. Eight-four burned-rock features were located, one with a radiocarbon date of 8955 (8655) 8545 B.P. associated with a Paleoindian period Angostura point. The results of this work verifies the 1994 findings of intact Early and Middle Archaic components as well as newly identified Late Paleoindian and Late Archaic components. Site 41BX47 is significant and is eligible for inclusion in the National Register. The mitigation of areas associated with the Late, Middle, and Early Archaic and the Late Paleoindian components offers potential to address important research issues concerning hunter and gatherer adaptations in south-central Texas. 


\section{CONTENTS}

ABSTRACT $\ldots \ldots \ldots \ldots \ldots \ldots \ldots \ldots \ldots \ldots \ldots \ldots \ldots \ldots \ldots \ldots \ldots \ldots \ldots$

FIGURES $\ldots \ldots \ldots \ldots \ldots \ldots \ldots \ldots \ldots \ldots \ldots \ldots \ldots \ldots \ldots \ldots \ldots \ldots$ iii

TABLES $\ldots \ldots \ldots \ldots \ldots \ldots \ldots \ldots \ldots \ldots \ldots \ldots \ldots \ldots \ldots \ldots$ iv

ACKNOWLEDGMENTS $\ldots \ldots \ldots \ldots \ldots \ldots \ldots \ldots \ldots \ldots \ldots \ldots \ldots \ldots \ldots \ldots$

CHAPTER 1: PROJECT SETTING AND BACKGROUND

INTRODUCTION $\ldots \ldots \ldots \ldots \ldots \ldots \ldots \ldots \ldots \ldots \ldots \ldots \ldots \ldots \ldots \ldots \ldots \ldots \ldots$

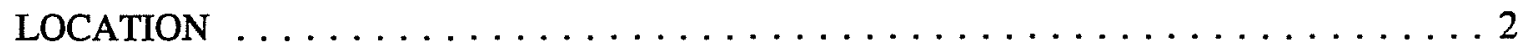

ARCHAEOLOGICAL BACKGROUND $\ldots \ldots \ldots \ldots \ldots \ldots \ldots \ldots \ldots \ldots \ldots \ldots \ldots$

CHAPTER 2: FIELD METHODS

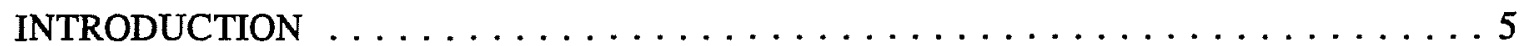

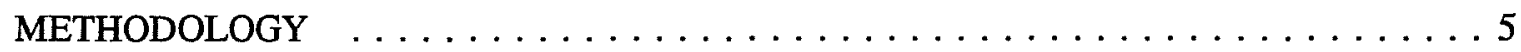

CHAPTER 3: GEOARCHAEOLOGY OF 41BX47, UPPER LEON CREEK BASIN

Lee C. Nordt

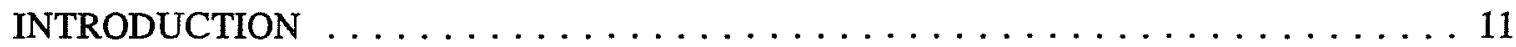

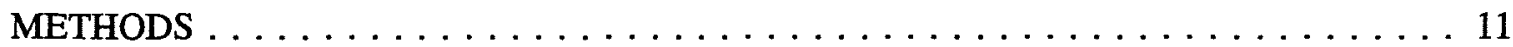

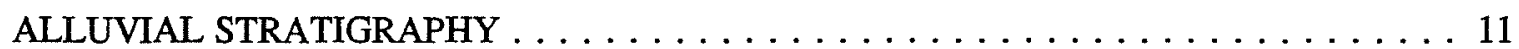

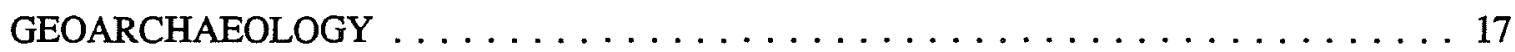

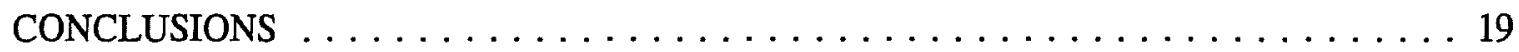

CHAPTER 4: RESULTS

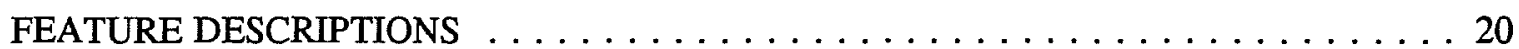

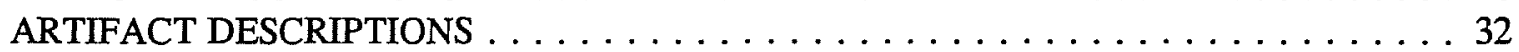

CHAPTER 5: ANALYSIS

FEATURE ATTRIBUTE ANALYSES $\ldots \ldots \ldots \ldots \ldots \ldots \ldots \ldots \ldots \ldots \ldots \ldots \ldots$

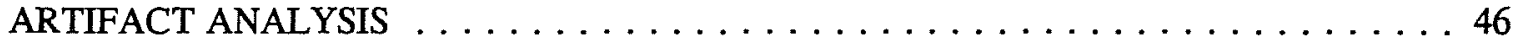

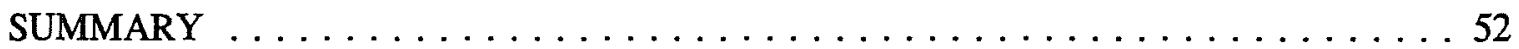

CHAPTER 6: HISTORIC CONTEXT AND RECOMMENDATIONS

Robert J. Hard and C. Britt Bousman

REVIEW OF PERTINENT ARCHAEOLOGICAL STUDIES $\ldots \ldots \ldots \ldots \ldots \ldots \ldots . \ldots 54$

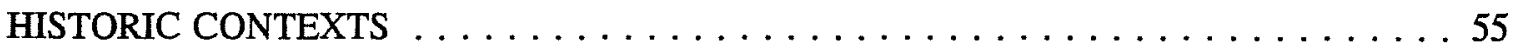

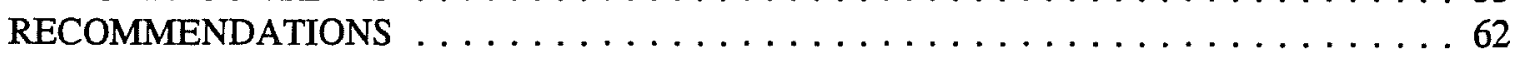

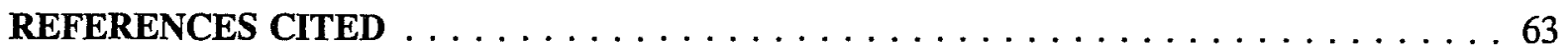

APPENDIX A: SOIL-STRATIGRAPHIC DESCRIPTIONS

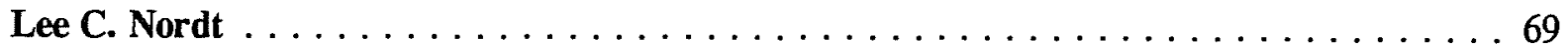

APPENDIX B: ARTIFACT CATALOG $\ldots \ldots \ldots \ldots \ldots \ldots \ldots \ldots \ldots \ldots$

APPENDIX C: ARCHEOMAGNETISM OF FEATURE 49

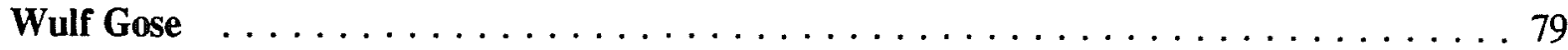




\section{FIGURES}

1. Regional chronology . . . . . . . . . . . . . . . . . . . . 3

2. Distribution of low, medium, and high density sample areas $\ldots \ldots \ldots \ldots \ldots \ldots 66$

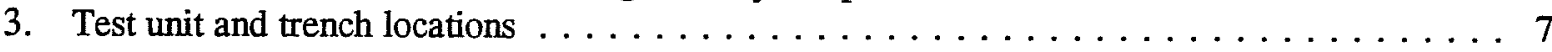

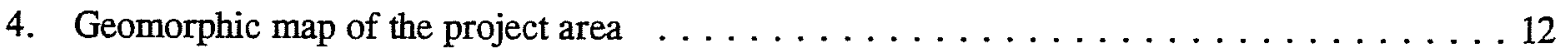

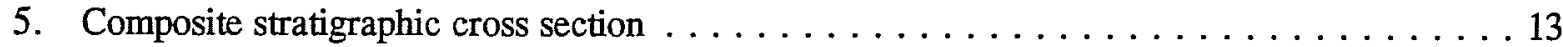

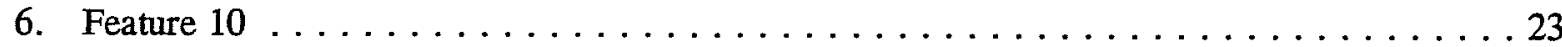

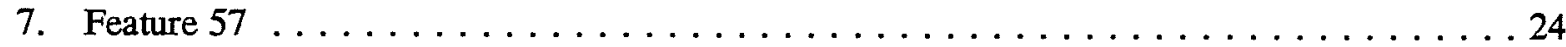

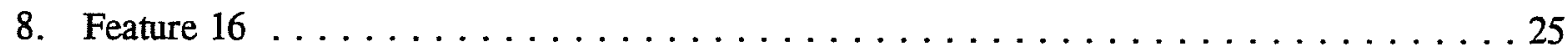

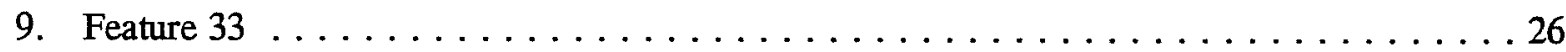

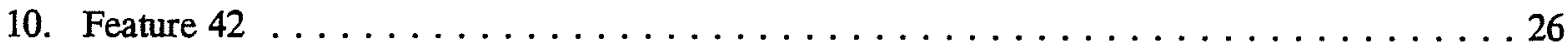

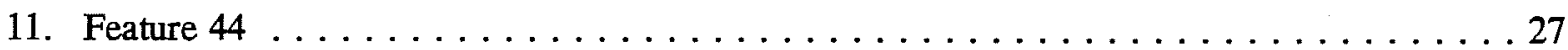

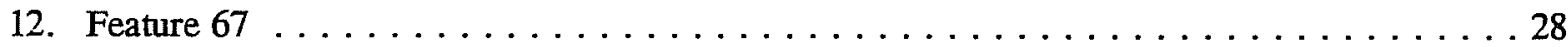

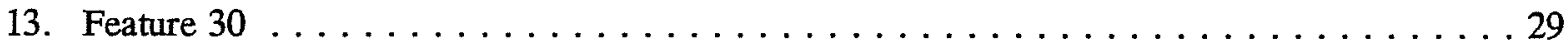

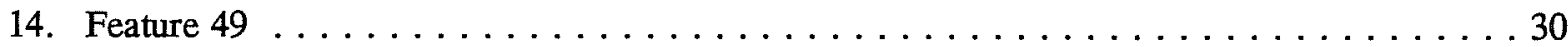

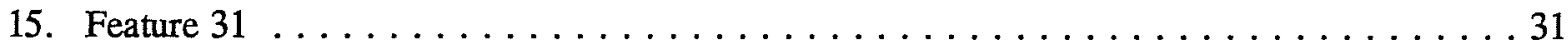

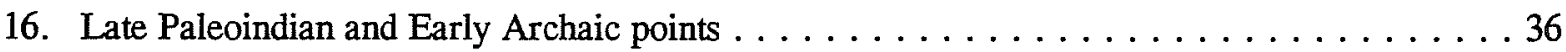

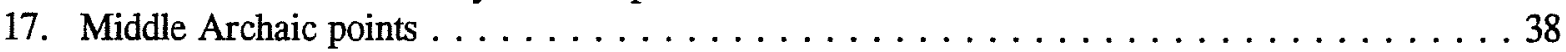

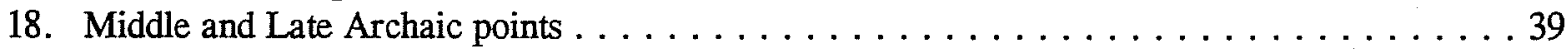

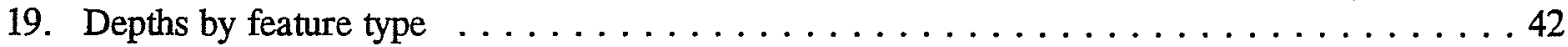

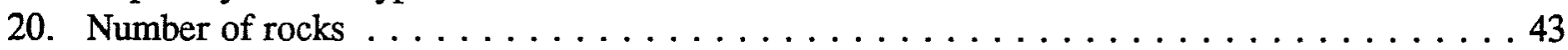

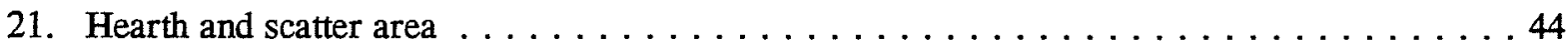

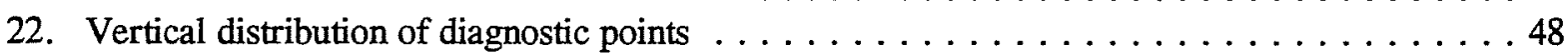

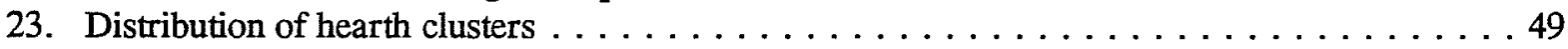

24. Vertical distribution of artifacts and features in the East Section $\ldots \ldots \ldots \ldots \ldots \ldots 50$

25. Vertical distribution of artifacts and features in the West Section $\ldots \ldots \ldots \ldots \ldots$

26. Vertical distribution of artifacts and features in the upper levels of the North Section . . . . 51

27. Vertical distribution of artifacts and features in the lower levels of the North Section . . . . 51

28. Archaeomagnetic orientations of hypothetical burned rock features $\ldots \ldots \ldots \ldots \ldots 7$

29. Capacity planning model for prehistoric features $\ldots \ldots \ldots \ldots \ldots \ldots \ldots \ldots \ldots \ldots \ldots \ldots \ldots$

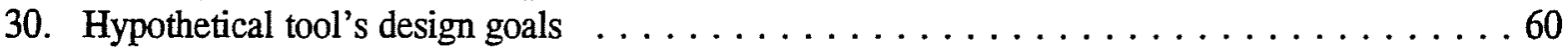

31. Tool utility/cost curves for different tool design goals $\ldots \ldots \ldots \ldots \ldots \ldots \ldots \ldots 6 . \ldots 6$

C-1. Vector component diagrams for all samples from Feature $49 \ldots \ldots \ldots \ldots \ldots$

C-2. Normalized intensity of magnetization as a function of temperature $\ldots \ldots \ldots \ldots \ldots 81$

C-3. Equal area stereograph projection of the directions of magnetization $\ldots \ldots \ldots \ldots \ldots 81$ 


\section{TABLES}

1. Gradall Trench and Features $\ldots \ldots \ldots \ldots \ldots \ldots \ldots \ldots \ldots \ldots \ldots \ldots$

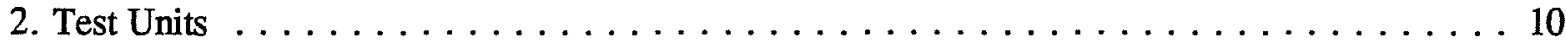

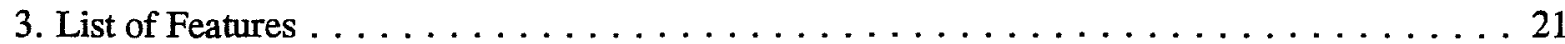

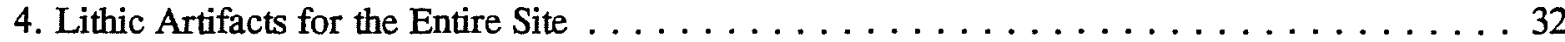

5. Vertical Distribution of Test Unit Artifacts $\ldots \ldots \ldots \ldots \ldots \ldots \ldots \ldots \ldots \ldots \ldots \ldots \ldots$

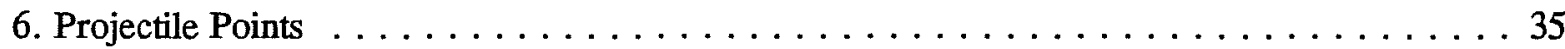

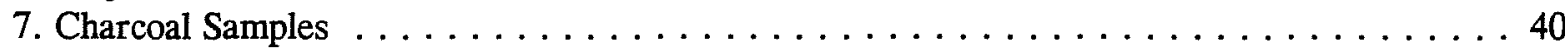

8. Radiocarbon Results . . . . . . . . . . . . . . . . . . . . . 41

9. Spatial Relationship of Features $\ldots \ldots \ldots \ldots \ldots \ldots \ldots \ldots \ldots \ldots \ldots \ldots 4 . \ldots \ldots \ldots$

10. Middle and Late Archaic Projectile Points Associated with Burned Rock Midden Features . . 46

11. Early Archaic Projectile Point Distributions $\ldots \ldots \ldots \ldots \ldots \ldots \ldots \ldots \ldots \ldots$. . . . . 47

12. Late Paleoindian Projectile Point Distributions $\ldots \ldots \ldots \ldots \ldots \ldots \ldots \ldots \ldots \ldots$

13. Density of Features and Number of Projectile Points and Grinding Stones

Per Feature at Selected Early Archaic Sites . . . . . . . . . . . . . . . 55 


\section{ACKNOWLEDGMENTS}

It was a pleasure to again work with John Rinehart and the staff of Pape-Dawson Engineers. Their assistance with mapping has been invaluable. Jim Rector and Calvin Brown, with Olmos Construction, were always available and ready with assistance when we needed it. Gabriel Sagredo with Aaron Construction did in three weeks with his Gradall what it would have taken us three months to do. We would like to thank Lee Nordt and Mike Waters for their advise on the complicated geomorphology of this group of terraces, and C. K. Chandler for his aid with point type identifications.
Thanks to the CAR field crew: Bobby Rector, Sandy Billingsley, Ed Johnson, Tony Lyle, Andrew Scease, Ward Bramlett, Rex Harris, Florencio Delgado, Connie Gibson, and Barbara Meissner for their diligent efforts. Bobby Rector is also responsible for the accurate artifact illustrations. Thanks also to Johanna Hunzinker and Laura Burgess for their speedy and thorough processing of the artifacts and to David Pease and Dave Nickels for their assistance with the mapping. Special thanks go to Marcie Renner, our technical editor, and Britt Bousman and Robert Hard, the co-principal investigators, for their guidance and assistance in and out of the field. 


\section{CHAPTER 1: PROJECT SETTING AND BACKGROUND}

\section{INTRODUCTION}

In March 1995 the Center for Archaeological Research (CAR) of The University of Texas at San Antonio (UTSA) conducted the second phase of archaeological work at 41BX47. This phase of intensive testing was designed to assess the significance of the Early and Middle Archaic deposits identified during the 1994 CAR survey of the 147 acre project area (Tennis and Hard 1995) and to determine the eligibility of $41 B X 47$ for inclusion in the National Register of Historic Places. These investigations were performed for Pape-Dawson Engineers to further comply with U. S. Army Corps of Engineers permit requirements and were reviewed and approved by the U.S. Army Corps of Engineers in consultation with the Texas Historical Commission (State Historic Preservation Office).

Previous work in the project area included an avocational archaeological survey by Paul McGuff and Bill Fawcett in 1970, during which four archaeological sites were identified. A preliminary reconnaissance of portions of the project area was conducted by CAR personnel in 1992 (Uecker 1992). Both of these surveys indicated archaeological material was present and further work would be needed before construction could begin. Because of the use of heavy equipment and the amount of earth movement planned for the construction project, a thorough survey was designed for the entire project area and carried out in July 1994 (Tennis and Hard 1995).

The fieldwork completed during the 1994 survey phase consisted of pedestrian survey, 222 shovel tests, excavation of one $1-\mathrm{x}-1-\mathrm{m}$ test unit, backhoe trenches, plowing, and a geomorphological study by Lee Nordt of Texas A\&M University. Through these tests and surface examinations, as well as the geomorphic and artifact analyses, new site boundaries were established, combining two of the previously recorded sites, 41BX40 and 41BX47, into one, largely intact, Early and
Middle Archaic period site, 41BX47, which covers approximately 30 acres of the project area. Horizontal and vertical distribution analyses of artifacts recovered from the shovel tests identified areas of high, medium, and low densities of lithic material in the north, east, and west portions of the site. The combined archaeological and geomorphological evidence indicates 41BX47 probably contained three spatially distinct components. A Middle Archaic component containing two Nolan points was identified in the northwest portion of the site. Early Archaic components containing one Gower and two Uvalde points were identified in the upper $50 \mathrm{~cm}$ on the east and west sides of the site. The third component was identified based on lithic material recovered from $80-110 \mathrm{~cm}$ below the surface (bs) in the southeast portion of the site during backhoe testing and could represent the earlier portions of the Early Archaic. Further investigations of this site were recommended prior to construction (Tennis and Hard 1995).

Based on this information, an intensive testing program was designed to address specific issues related to the significance and eligibility of 41BX47. This phase of archaeological investigation, which consisted of fourteen 1-x-1-m hand-excavated tests units, 59 Gradall trenches, and additional geomorphological study, was designed to assess the integrity of the three previously identified archaeological components through: 1) the presence of intact features; 2) the existence of dateable artifact clusters; and 3) the presence of floral or faunal material.

These testing investigations revealed a total 79 burned-rock features and 4,271 chipped stone artifacts including 24 diagnostic projectile points from the Late Paleoindian, and Early, Middle, and Late Archaic time periods. The features appear in undisturbed context and represent elements of three horizontally and vertically discrete components. The Middle and Late Archaic component consists of two to three large midden-like accumulations of extensively 
cracked limestone and several hearths. These features are found from $10-30 \mathrm{~cm}$ bs in two areas along the west and northwest edge of the site and are associated with Bulverde, Pedernales, Kinney, Marshall, Pandora, and Marcos points. The Early Archaic component is represented by two large oven-like accumulations of lightly cracked and uncracked limestone and over 50 small hearths. These features occur from $40-110 \mathrm{~cm}$ bs, primarily in the eastern portion of the site and occur at depths that have also revealed Early Corner-notched, Gower, and Hoxie projectile points. The Late Paleoindian component consists of three lightly burned hearths from $120-180 \mathrm{~cm}$ bs revealed in a single 1-x-1-m unit in the northern portion of the site. At a depth of $125 \mathrm{~cm}$ bs, a Late Paleoindian Angostura point was recovered from between two hearth features. An additional feature was uncovered at $170 \mathrm{~cm}$ bs in this same unit.

Robert J. Hard and C. Britt Bousman served as co-principal investigators with Cynthia Tennis as project archaeologist. All research notes, field and laboratory records, and artifacts are curated at the CAR laboratory.

\section{LOCATION}

The 147-acre project area is located in northwest San Antonio. The area is situated on an inside meander of Leon Creek, one of several prominent streams draining the Edwards Plateau to the north. Major drainages in the area include the Guadalupe River to the north; the San Antonio River to the south; and the Medina River to the south and southwest, into which Leon Creek empties south of the downtown area.

The land surface in the project area slopes gently up from the creek, rising only eight feet from the modern floodplain (T0) and includes a first (T1), second (T2), third (T3), and fourth (T4) terrace. These terraces were created through repeated episodes of erosion and overbank deposition as the creek shifted location through time. Vegetation consists of large native oak and hackberry trees along the edge of the creek which are replaced by mesquite and persimmon on the terraces.

Soils in the project area are a combination of Patrick soils, Lewisville silty clay, and Venus loam (Taylor et al. 1991). Patrick soils, which make up slightly more than half the soil within the study area, consist of shallow clay loams, gravelly clay loams, or silty clays which occur as level to gently sloping terraces along streams draining the limestone prairies to the north. These soils generally have deep beds of limecoated, waterworn, limestone gravel beds within one meter of the surface. The Lewisville silty clay is a dark, nearly level alluvial soil that generally separates level terraces from upland soils. This soil is moderately deep, ranging from 91-125 cm and is often underlain by deep beds of water-rounded limestone gravels. Venus loam makes up only a small portion of the soil in the project area and is described as a moderately dark, deep loam or clay loam soil that occupies narrow terraces along major watercourses. Just to the east, is a section of Crawford and Bexar stony soils, characterized as stony clay over limestone composed of 10-40 percent chert.

\section{ARCHAEOLOGICAL BACKGROUND}

Although more archaeological sites have been recorded and excavated in central Texas than in any other part of the state, the cultural history and chronology of the area are still unclear and remain topics of investigation and debate (Black 1989; Collins et al. 1990; Johnson 1986, 1991; Johnson and Goode 1994; Potter and Black 1995; Prewitt 1981, 1985). Researchers have expressed different views on the chronological divisions and associated terminology for the major time periods of central and south Texas prehistory. This confusion arises, at least in part, from the very nature of the sites being investigated, and the long period of yet undifferentiated hunter-gatherer adaptations they represent. The description of the region's cultural history given here will be limited to the 
generally agreed upon description of the three major periods: Paleoindian, Archaic, and Late Prehistoric (Figure 1).

The Paleoindian period (ca. 11,000-8000 B.P.) has been described as a time when small, highly mobile bands of hunters exploited herds of nowextinct large mammals at the end of the Pleistocene. Recent studies at the WilsonLeonard site, Burger Bluff site, and 41BX52 promise to increase our understanding of the role played by small game and plant foods in the subsistence strategies of this period (Black 1989).

The Archaic period (ca. $8000-1150$ B.P.) encompassed a 7,000-year period of huntingand-gathering adaptations following the Pleistocene. The division of the Archaic into Early, Middle, and Late periods is based primarily upon changes in projectile point styles. In the Early Archaic period, population densities were probably low. Small, highly mobile bands exploited a wide variety of resources (Weir 1976). Sites were concentrated along the Balcones Escarpment because of its concentration of springs and streams (McKinney 1981, Story 1985). During the Middle Archaic, burned-rock midden features were widespread, suggesting the formation of a more specialized economy and increased population density (Weir 1976). By the Late Archaic period, the frequency of burned-rock midden features declined and bison bones increased, suggesting another shift in subsistence strategies (Dillehay 1974). Several large cemetery sites may indicate increased territorialism (Story 1985) and the distribution of certain grave goods may reflect the existence of trade networks (Hall 1981).

During the Late Prehistoric period (ca. $1150-350$ B.P.) hunters and gatherers adopted the bow and arrow and apparently made greater use of protected rockshelter locations. Population density may have declined and burials with embedded projectile points signal increased intergroup conflict (Prewitt 1985; Shafer 1977; Skinner 1981). Toward the end of the Late Prehistoric period, a shift in lithic technology,

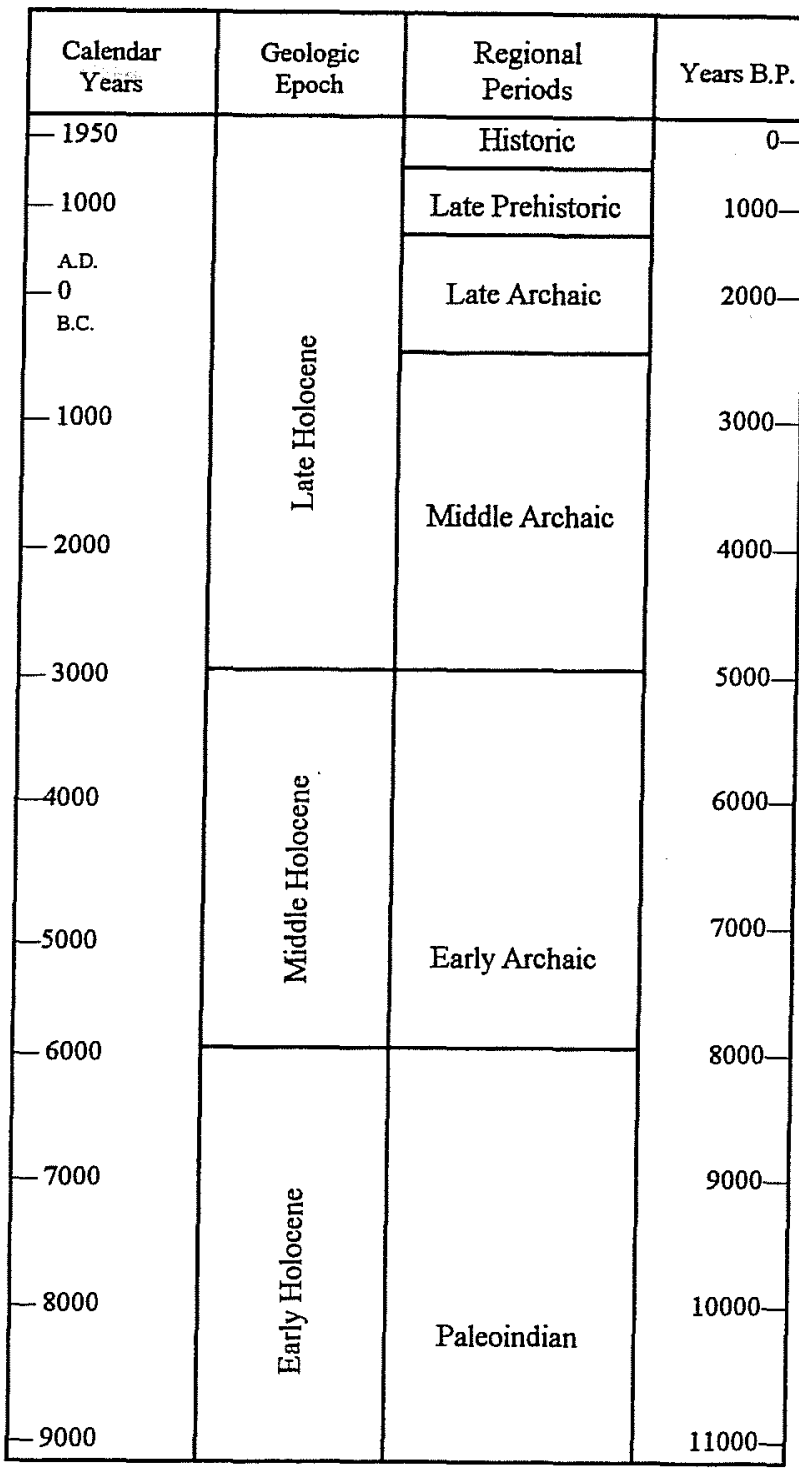

Figure 1. Regional chronology.

subsistence, and the introduction of ceramics indicate changing adaptations which are not well understood. Some investigators suggest that a migration into the area or increased interactions with peoples from outside central Texas occurred (Assad and Potter 1979; Harris 1985; Shafer 1977).

The pace of archaeological investigations over the past 25 years in Bexar County is reflected by the growth in the sequential trinomial numbers given to archaeological sites. In 1970 trinomial numbers 41BX40, 41BX47, 41BX48, and 
41BX50 were assigned to sites within the study area. By 1996 , over 1,000 additional sites had been recorded. Sites in Bexar County contain cultural remains spanning the entire prehistoric human occupation in central Texas, including Paleoindian components from the St. Mary's Hall site (Hester 1978) and Olmos Dam (Stothert 1989); Archaic components from the Panther Springs Creek site (Black and McGraw 1985), the Richard Beene site (Thoms 1992), and the Wurzbach Road Project (Potter et al. 1995; Potter and Black 1995); and Late Prehistoric components from 41BX274 (McGraw and Hindes 1987).

A search of records in the CAR files revealed that 15 sites, including the four located on the property under study, have been recorded within a three-kilometer radius of the current project. These sites are all located along Leon Creek or one of its smaller tributaries. With the exception of 41BX52, a Paleoindian site excavated by the Texas Highway Department which is being reanalyzed by Michael Collins of the Texas Archeological Research Lab (TARL) in Austin, none of these sites has been further investigated. However, from a review of the site forms on file at CAR, it is evident that the Leon Creek drainage was utilized by the prehistoric people of the region for many millennia.

Four sites, 41BX40, 41BX47, 41BX48, and 41BX50, were recorded within the project area in 1970 by Paul McGuff and Bill Fawcett. Site 41BX40 was described as a possibly Late Paleoindian open campsite on the floodplain below the dammed portion of Leon Creek. Site 41BX 47 was described as a large, open campsite on a river terrace, containing Archaic projectile points, clusters of burned or fire-cracked rock, and other artifacts. Site $41 B X 48$ was described as a two-foot wide remnant of topsoil on a peninsula whose western edge was eroded down to gravel by the creek and the east side was destroyed by a road and quarry. Site 41BX50 was described as a site of unknown dimensions near the southeast boundary of the present project. Findings from the 1994 CAR survey (Tennis and Hard 1995) indicate that 41BX48 no longer exists, $41 \mathrm{BX} 50$ has been heavily damaged by dumping and other unknown activities, and $41 B X 40$ is actually part of $41 B X 47$, now under investigation. 


\section{CHAPTER 2: FIELD METHODS}

\section{INTRODUCTION}

The archaeological and geomorphological evidence obtained from the survey and shovel tests conducted during the initial phase of investigation at the project area indicated that Early and Middle Archaic components were present at 41BX47 (Tennis and Hard 1995). This current phase of investigation was designed to determine the eligibility of $41 \mathrm{BX} 47$ for inclusion into the National Register of Historic Places through assessment of the integrity of these temporal components.

The stratified fieldwork design for this phase of testing was based on the results of the 1994 survey (Tennis and Hard 1995). During this project, sampling areas were defined by artifact density identified from shovel tests results. Low density areas were defined by 1-4 artifacts per test, medium density by 5-9 artifacts, and high density by 10 or more (Figure 2). A series of Gradall trenches and excavations units were placed within these sample areas to identify intact features, dateable artifact concentrations, and floral and faunal deposits that would verify site integrity and significance (Figure 3).

\section{METHODOLOGY}

Archaeological fieldwork consisted of fourteen $1-\mathrm{x}-1-\mathrm{m}$ tests units, one $.50-\mathrm{x}-1-\mathrm{m}$ test unit, and 59 Gradall trenches. Additional trenching for geomorphological investigations was also conducted.

\section{GRADALL TRENCHES}

The initial scope of work called for the arbitrary placement of Gradall trenches in each of the areas of high, medium, and low artifact sample areas. Gradall trenches were also placed in the portion of the plowed field where a deeply buried deposit was identified in the 1994 survey. The number of trenches placed in each sample area was determined by the size of the area to be tested and is summarized in Table 1.

The size of the site and irregular shape of the areas made the use of a standard north/ south by east/west grid impractical. Instead, each trench was assigned an alpha-numeric label based on the density of the sample area in which it was located, the letter $\mathrm{G}$ for Gradall, and the order in which it was dug. For example, the first trench dug in low density area L1 was designated L1/G1. The two trenches dug to placed in the vicinity of the previously identified buried deposit were labeled GT1 and GT2. The trenching in the sample areas was completed during the first two weeks in the field. However, became numerous features were discovered, the scope of Gradall work was extended for an additional week to examine sections outside the sample areas. Trenches were placed in the untested portions of the upper terraces in the plowed field to identify the extent of the features. These trenches were labeled F/G (Field Gradall) and consecutively numbered. Trenches placed to the north of the site were labeled ND1 and ND2 (Figure 3). These sections outside of the artifact density sample areas became known as "field sample areas."

Labeled shovel test holes from 1994 were used as landmarks for the placement of trenches within the known density areas. Trenches were aligned north-south or east-west from these points. Trenches in the untested portions of the plowed field were aligned east-west and were placed approximately $25 \mathrm{~m}$ apart in a staggered alignment to allow access to these trenches by similar equipment in the future. Gradall trenches are $1.7 \mathrm{~m}$ wide (the width of the Gradall bucket) and an average of $25 \mathrm{~m}$ long. The location of each trench was plotted in the field using the pace and compass method. The trench designation and date were marked on flagging 
This page has been

redacted because it

contains restricted

information. 
This page has been

redacted because it

contains restricted

information. 
Table 1. Gradall Trench and Features

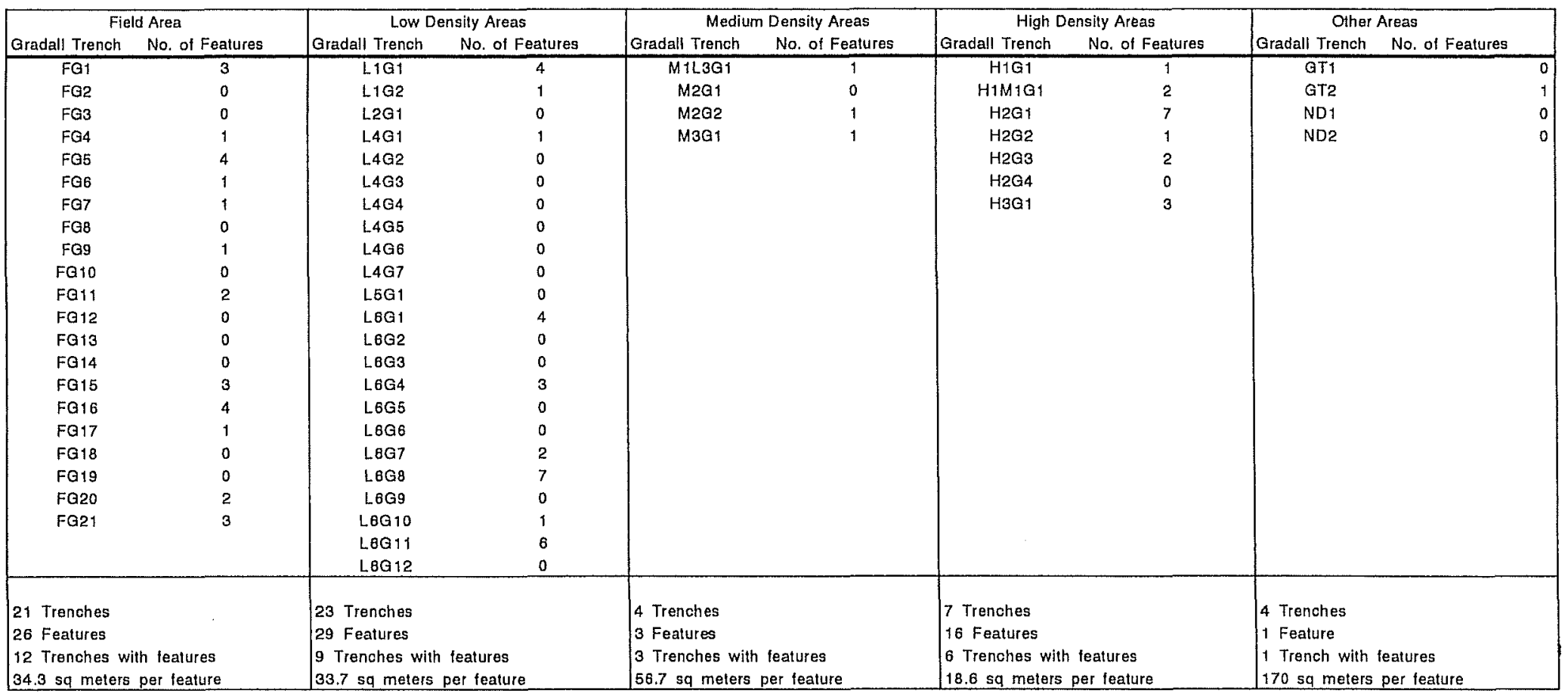


tape which was affixed to the wall at the beginning of each trench with a nail. Gradall trenches, excavation units, and features were mapped with an EDM total station.

\section{MONITORING}

The excavation of each trench was monitored at all times by a two-person team. One person monitored the actual excavation while the other monitored the backdirt. A metric tape was laid out along the 25-m length of the area to be trenched to serve as a guide for the Gradall operator and for linear control for plotting objects observed during excavation. Because of the mobility limitations of the Gradall, trenches were excavated in sections averaging $3-4 \mathrm{~m}$ in length. Soil was removed in 5-cm levels. Each level was monitored for the presence of burned or fire-cracked rock features or artifact concentrations. When the top of a burned rock was scraped by the Gradall bucket, it left distinctive gray smear on the bottom of the trench. Areas around these smears were cleared by hand to expose any additional rocks. If the exposed rock proved to be isolated, its depth and location in the trench were plotted on the trench form and mechanical excavation continued in that section.

When hand excavations revealed a concentration of burned rocks, the depth below surface and location in the trench were plotted on the trench form. Artifacts associated with the feature were recorded and left in situ. The approximate center of each feature was marked with flagging tape, bearing a sequential Feature Number, secured by a metal nail. Mechanical excavation ceased in that section and the Gradall was repositioned to begin excavation of the next section in the trench. This procedure was repeated for the remainder of the $25 \mathrm{~m}$ length of the trench, with the depth of subsequent sections remaining on the same level as the exposed feature. In trenches where no features were encountered, excavation continued to depths of approximately $1.5 \mathrm{~m}$ bs or until the gravel layer was reached.

\section{TEST UNITS}

Placement of the 1-x-1-m test units was also based on the sample areas identified in the 1994 survey. To maximize the potential for artifact recovery, these tests units were located in medium and high density sample areas. The number of test units placed in each of the medium and high density areas varied with the size of the area being tested. The actual location of units within these areas was arbitrarily selected.

Each 1-x-1-m test unit was assigned an alphanumeric label based on the sample area in which it was located, the letter $U$ for unit, and the order in which it was excavated. Thus, M1/U1 designates the first test unit in medium-density sample area 1. Four tests units were also placed in the buried component in the field. These units were hand excavated to a depth of $110 \mathrm{~cm}$ bs after the removal of top $60-70 \mathrm{~cm}$ by Gradall. These four units are labeled according to the Gradall trench where they occurred (i.e. GT1/U1).

Units were excavated in arbitrary $10-\mathrm{cm}$ levels with vertical provenience maintained by unit datums established at the corner with the highest surface elevation. A unit level form, completed for each 10-cm level, recorded the number and type of artifacts recovered, a soil description, percent of gravel present, and disturbances. Dirt from all but one unit was screened through $1 / 4-$ inch hardware cloth; $1 / 8$-inch was used in one unit to insure recovery of small flakes noted in this unit. However, this material was resorted through $1 / 4$-inch screen in the lab, and only those artifacts remaining in the screen are used in quantitative comparisons. All excavations continued until a depth $10 \mathrm{~cm}$ in the sterile zone was reached, or until the gravel content exceeded 50 percent of the level, or when a feature was exposed. The number of units excavated in each density area, their maximum depths, and the rational for termination of excavation are summarized in Table 2. 
Table 2. Test Units

\begin{tabular}{|c|c|c|c|c|c|c|c|c|}
\hline \multicolumn{3}{|c|}{ Field Sample Area } & \multicolumn{2}{c|}{ Medium-density Sample Areas } & \multicolumn{2}{c|}{ High-density Sample Areas } \\
\hline Unit & $\begin{array}{c}\text { Depth } \\
(\mathrm{cm})\end{array}$ & $\begin{array}{c}\text { Termination } \\
\text { Reason }\end{array}$ & Unit & $\begin{array}{c}\text { Depth } \\
\text { (cm) }\end{array}$ & $\begin{array}{c}\text { Termination } \\
\text { Reason }\end{array}$ & Unit & $\begin{array}{c}\text { Depth } \\
\text { (cm) }\end{array}$ & $\begin{array}{c}\text { Termination } \\
\text { Reason }\end{array}$ \\
\hline GT1/U1 & $60-120$ & sterile & M1/U1 & $0-50$ & feature & H1/U1 & $0-40$ & FCR \\
\hline GT1/U2 & $60-120$ & sterile & M1/U2 & $0-80$ & sterile & H2/U1 & $0-100$ & gravel \\
\hline GT2/U1 & $60-120$ & sterile & M2/U1 & $0-60$ & gravel & H2/U2 & $0-260$ & sterile \\
\hline GT2/U2 & $70-120$ & sterile & M3/U1 & $0-50$ & FCR/gravel & H2/U3 & $0-30$ & gravel \\
\hline
\end{tabular}

FEATURES

Special procedures were employed to record each of the burned-rock features encountered in Gradall trenches and test units at 41BX47. The area around the exposed feature was cleared by hand, removing only enough soil to reveal the extent and shape of the rock cluster while leaving the individual rocks and any associated artifacts in situ. Scaled plan maps were drawn and the location, depth, shape, dimensions, number of rocks, artifacts, and conjoins (fragments of articulated but broken rock remaining in place) for each feature were recorded on special feature forms. Color slides and black-and-white photos were also taken. After the recording was completed, artifacts were collected.

Four features, three in test units and one in a trench, were selected for excavation. Rocks were numbered in situ and drawn on the plan map before excavation began. Features were bisected to reveal their internal structure and profiles were drawn of the sections. Matrix from within and around each feature was collected for flotation to provide an indication of floral and faunal preservation for future investigations.

\section{ARCHAEOMAGNETIC SAMPLES}

Archaeomagnetic samples were taken from one feature to determine if the rock in the feature had moved since its last firing. Samples were removed from seven in situ burned rocks using a paleomagnetic drill. Each sample was scored with a brass wire to establish its orientation within the feature and the dip and strike of each sample was recorded from the goniometer reading. Samples were transported to Wulf Gose of the Department of Geological Sciences at The University of Texas in Austin for analysis.

\section{BACKHOE TRENCHES}

Under the direction and supervision of the geomorphological consultant, Lee Nordt, profiles from two new backhoe trenches (BHTA and BHTB), one excavation unit (H2/U2), and one Gradall trench (F/G2) were described. These trenches were placed in previously untested portions of the site to clarify geomorphological questions that remained unresolved after the 1994 survey (Nordt 1994). The geomorphological profile descriptions are presented in Appendix A, and a discussion of the geological results is presented in the following chapter. 


\title{
CHAPTER 3: GEOARCHAEOLOGY OF 41BX47, UPPER LEON CREEK BASIN
}

\author{
Lee C. Nordt
}

\section{INTRODUCTION}

The study area is located in a late Quaternary alluvial setting of Leon Creek about $20 \mathrm{~km}$ below its headwaters. Above the study area, isolated pockets of alluvium fill an entrenched limestone valley, while below the study area the alluvial valley is continuous. Most of the Leon Creek basin drains the Cretaceous Edwards Limestone undivided and the Anacacho Limestone (Barnes 1983). These geologic units have contributed mostly limestone and chert to the alluvial valley during the late Quaternary.

The objectives of the geoarchaeological investigation were to 1) spatially and chronologically delineate alluvial environments of deposition, and 2) assess the influence of these environments on the spatial and temporal distribution of the archaeological record.

\section{METHODS}

The late Quaternary alluvial record of Leon Creek within the study area was constructed from over 20 backhoe trenches, numerous bore holes (Raba-Kistner Consultants, Inc., 1994) and Gradall trenches, one cutbank exposure, the Castle Sands 7.5 minute topographic map (U.S. Geological Survey 1992), and the Soil Survey of Bexar County, Texas (Taylor et al. 1966). Selected study localities are shown in Figure 4.

The alluvial terraces were differentiated mainly by elevation and susceptibility to flooding. Soilstratigraphic descriptions were written following standards and procedures of the Soil Survey Division Staff (1993). Selected descriptions are provided in Appendix A. Alluvial stratigraphic units were informally defined as unconformably bound packages of sediment having unique spatial and chronological distributions.

The alluvial stratigraphic chronology was based on two carbon-14 ages from bulk humate samples (Beta Analytic Inc.), diagnostic artifacts, degree of soil development, and correlations to other central Texas alluvial stream histories.

\section{ALLUVIAL STRATIGRAPHY}

Five late Quaternary landforms are mapped in the study area: one terrace (T4), three flood terraces ( $\mathrm{T} 3, \mathrm{~T} 2$, and $\mathrm{T} 1)$, and the floodplain (TO) (Figure 4). Associated with these landforms are five late Quaternary stratigraphic units (Units I-V) and one truncated buried soil (Figure 5). The stratigraphic units are subdivided into three depositional facies: a gravelly and sandy channel phase (c), a fine-grained floodbasin and fine-grained chute phase (f), and a channel-fill phase (n).

\section{UNIT I}

\section{Lithology}

Terrace 4 (T4) is situated 5-6 $\mathrm{m}$ above the modern low-water channel of Leon Creek on the south side of the valley (Figure 4). Unit I, which outcrops in the vicinity of BHT-16, is the oldest alluvium beneath T4 (Figures 4 and 5; A-A'). The soil in BHT-16 developed in floodbasin deposits of Unit I-f and consists of a very dark brown and calcareous silty clay loam surface horizon over a strong brown to reddish yellow silty clay loam Bk subsoil horizon (Appendix A). Pedogenic $\mathrm{CaCO}_{3}$ nodules occur between a depth of 41 and $243 \mathrm{~cm}$, with a maximum accumulation of 20 percent between 72 and $123 \mathrm{~cm}$. The 
This page has been

redacted because it

contains restricted

information. 
A

T4

$A^{\prime}$

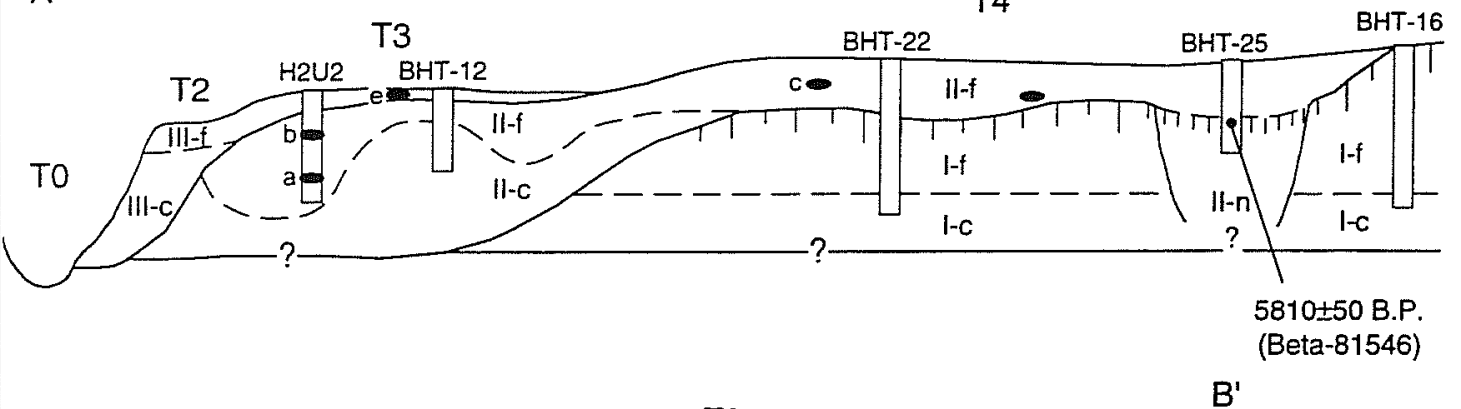

B

T3

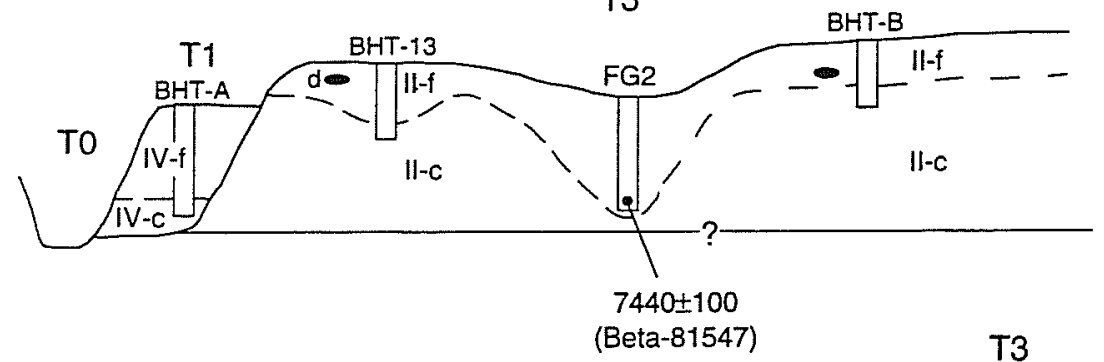

C
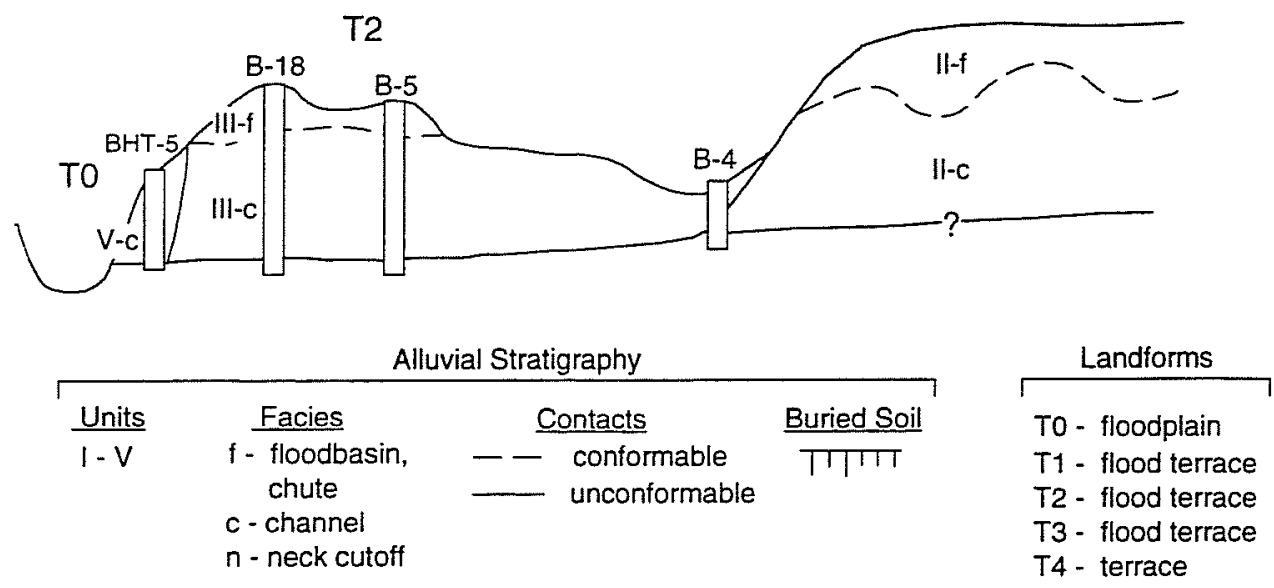

Cultural component

a - late Paleoindan-Early Archaic

$\square$ borehole $(\mathrm{B})$, backhoe trench $(\mathrm{BHT})$,

gradall trench (FG), test pit (H2U2)

b - Early Archaic

c - Early Archaic

d - Early Archaic-Middle Archaic

A' A transect

- Carbon-14 age

$C^{\prime}$

e - Early Archaic-Late Prehistoric

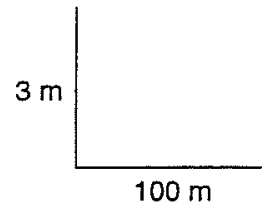

Figure 5. Composite stratigraphic cross section. Alluvial units and buried soils, following the transect lines shown in Figure 4. 
unaltered $\mathrm{C}$ horizon is a massive reddish brown sandy clay loam with a few matrix-supported pebbles.

Unit I-f is truncated and buried by younger deposits in the area of BHT-22. Below the erosional unconformity at $98 \mathrm{~cm}$, Unit I-f consists of a reddish yellow silty clay loam $\mathrm{Bk}$ horizon having 5-8 percent nodules of $\mathrm{CaCO}_{3}$. This horizon grades down to a reddish yellow sandy loam Bk horizon containing 2 percent $\mathrm{CaCO}_{3}$ nodules (Appendix A). Between a depth of 210 and $298 \mathrm{~cm}$, the unweathered parent material (I-c) consists of alternating beds of carbonate-cemented and grain-supported channel pebbles, occasional matrix-supported pebbles, and unconsolidated reddish yellow loamy sand. Matrix colors and carbonate morphology for Unit $I$ in BHT-22 are similar to those in the subsoil of BHT-16 for Unit I.

In BHT-24, about $30 \mathrm{~m}$ to the north of BHT-16, Unit I-f consists a truncated $\mathrm{Bkm}$ horizon about $50 \mathrm{~cm}$ thick. The amount of $\mathrm{CaCO}_{3}$ contained in the $\mathrm{Bkm}$ horizon would have required complete decalcification of the overlying sediments. Because the sediments above the $\mathrm{Bkm}$ are highly calcareous, the original surface horizons pedogenically related to the $\mathrm{Bkm}$ were eroded and replaced with Unit II-f deposits. Development of the $\mathrm{Bkm}$ horizon indicates an older age than the soil described in BHT-16, however, they are both tentatively correlated with Unit I.

Based on lithology and facies relations, Leon Creek appears to have been a fine-grained meanderbelt carrying uniform base flow during deposition of Unit I. Flood magnitudes were probably less than today.

\section{Chronology}

The numerical age of Unit $I$ is unknown. However, it must be older than the oldest artifact discovered in Unit II, which was an Angostura point dated to between 8800 and 8000 B.P. (Figure 5, H2/U2 - Component a). Furthermore, the $\mathrm{Bkm}$ horizon suggests that Unit $\mathrm{I}$ is older than 8800 to 8000 B.P. and possibly Pleistocene in age. Degree of soil development and lithology of Unit I along Leon Creek is similar to both the late Pleistocene Jackson alluvium (ca. 15,000 B.P.) and Early Holocene Georgetown alluvium (ca. 10,000 to 8000 B.P.) recognized at Fort Hood in central Texas (Nordt 1992, 1995).

\section{UNIT II}

\section{Lithology}

Unit II unconformably overlies Unit I and is genetically related to both the $\mathrm{T} 3$ flood terrace and the T4 terrace (Figures 4 and 5; A-A', B-B', $\left.C^{-} C^{\prime}\right)$. T3 is considered a flood terrace because it is situated only 4.5 to $5 \mathrm{~m}$ above the modern low-water channel and is consequently more susceptible to flooding. Unit II consists of channel gravel (lic) and floodbasin/chute and channel fill (II-f) facies.

The floodbasin facies of Unit II was exposed in BHT-22 and BHT-25 of T4 and in BHT-B of T3. This facies has been pedogenically altered to very dark grayish brown to black clay loam $\mathrm{A}$ horizons, over brown to yellowish brown clay loam Bk horizons having filaments and threads of $\mathrm{CaCO}_{3}$ (Appendix A).

Chute fills are associated exclusively with the T3/Unit II-f assemblage and are represented in $\mathrm{H} 2 / \mathrm{U} 2$, BHT-13, and FG2. Fine-grained lithology, carbonate morphology, and calcareous surface horizons in the chute fills of T3 are similar to the floodbasin facies associated with T4, thus supporting their correlation (Appendix A). The main difference between the floodbasin and chute facies of Unit II is that the latter sometimes contains more sand (i.e. sandy clay loam vs clay loam).

A buried soil was identified in Unit II at a depth of $98 \mathrm{~cm}$ in BHT-25 of T4. It consists of a dark brown and clayey $\mathrm{A}$ horizon overlying a brown and clayey Bssk horizon having slickensides and 1 percent nodules of $\mathrm{CaCO}_{3}$ (Appendix A). The buried soil developed in fine-grained sediment that filled a channel cutoff of Unit II-n. The soil 
is now conformably buried by floodplain deposits of Unit II-f.

The thick channel facies of Unit II-c consists of grain-supported and moderately well-sorted pebbles and cobbles (Appendix A). Matrix colors are generally yellowish brown and reddish brown. The channel gravels occur at depths ranging from about $50 \mathrm{~cm}$ (BHT-12) on ridge bars to more than $300 \mathrm{~cm}$ (FG2) in chute fills.

Facies relationships and lithology indicate that Leon Creek was a low sinuosity bedload stream at this time. The increase in channel gravel size and abundance and decrease in sorting in Unit II as compared to Unit I, suggests a change in hydrological regime from low flood magnitudes in the late Pleistocene and Early Holocene to more flashy flood magnitudes sometime in the Holocene.

\section{Chronology}

The deeply buried Angostura component in H2/U2 (Component a) and a carbon-14 age of $7440 \pm 100$ B.P. (Beta-81547) from FG2 demonstrate that deposition of Unit II was underway by 8800 to 7400 B.P. (Figure 5). Consequently, channel downcutting and formation of the scarp separating $\mathrm{T} 3$ and $\mathrm{T} 4$, burial of truncated remnants of Unit $I$, and partial construction of $\mathrm{T} 3$ occurred prior to, or near, 8800 to 7400 B.P. Furthermore, by this time Leon Creek had already migrated to the vicinity of H2U2 and BHT-12 and formed a gravel bar between these localities and the T3/T4 scarp.

The Unit II-f channel cutoff buried beneath T4 was probably active as early as 8800 to 7400 B.P. when deposition from the trunk channel was forming T3 to the north. A carbon-14 age from the surface horizon of the buried soil shows that the channel cutoff had been abandoned and was completely filled by $5810 \pm 50$ B.P. (Beta-81546). The fill of the channel cutoff and associated soil were conformably buried shortly after 5810 B.P. by deposition from the trunk stream to the north. The soil that developed in the upper part of Unit I-f was probably truncated by erosion from both the channel cutoff and the trunk channel of Leon Creek at the beginning of Unit II times.

Dating of the T3 surface is more problematic. In the initial archaeological survey of this project, Nolan, Uvalde, and Gower points were identified on the surface of T3. These points are synchronous with Component $b$ in $\mathrm{H} 2 / \mathrm{U} 2$ containing a Gower point, with Component $\mathrm{c}$ near BHT-22 containing a Uvalde point, and with the carbon-14 age of 5810 B.P. from the Unit II-f channel fill beneath T4 (Figure 5). These time-diagnostic points, both surface and subsurface, indicate that aggradation of Unit II terminated shortly after 5000 B.P.

However in the current testing phase, Pedernales, Kinney, and Marcos points were discovered in Gradall fill thought to have originated from within the $\mathrm{A}$ and upper $\mathrm{Bk}$ horizons of soil associated with the T3/Unit II assemblage (Figure 5, Components $\mathrm{d}$ and e). These buried Middle and Late Archaic points indicate that floodbasin sediments from the younger T2/Unit III assemblage partly buried Unit II during the late Holocene. Soil stratigraphic evidence for this is clear in $\mathrm{H} 2 / \mathrm{U} 2$ where a weakly developed A-Bw soil profile from Unit III buries an A-Bk profile developed in Unit II (Appendix A). However, the remaining backhoe and Gradall trenches in Unit II show no direct evidence for a near-surface stratigraphic unconformity. However, both Early and Middle Archaic points were found on the modern surface during the earlier survey phase. Consequently, the buried Middle and Late Archaic points in these areas indicate that 1) the surface horizon of the T3/Unit II soil was eroded and replaced with floodbasin deposits from Unit III, or 2) these Middle Archaic points were originally surface components associated with Early Archaic points and subsequently worked down into the T3/Unit II soil by bioturbation and plowing. Except in the area of $\mathrm{H} 2 / \mathrm{U} 2$ and BHT12 , the latter seems most likely and indicates that deposition of Unit II and construction of T3 probably terminated, and was available for occupation, shortly after 5000 B.P. Regardless, 
the bulk of Unit II deposition appears to have occurred between 8800 and 5000 B.P.

The age range, lithology, color, and degree of soil development of Unit II along Leon Creek are similar to the middle Holocene Fort Hood alluvium at Fort Hood (Nordt 1992, 1995), the middle Holocene Medina paleosol along the Medina River (Thoms and Mandel 1992), and the latter part of the early Holocene fill of the Pedernales River (Blum and Valastro 1989).

\section{UNIT III}

\section{Lithology}

Unit III is genetically related to $T 2$, both of which are laterally inset to the T3/Unit II assemblage. Because $\mathrm{T} 2$ is immediately adjacent to the modern Leon Creek channel (Figures 4 and 5; A-A', C-C'), and is susceptible to flood inundation, it is mapped as a flood terrace. Only one backhoe trench was excavated in Unit III (BHT-3). Here, the truncated Bk horizon was developed through the Unit III-c facies and contained 5 percent filaments of $\mathrm{CaCO}_{3}$ on cobbles. This degree of pedogenic $\mathrm{CaCO}_{3}$ development is somewhat less than in the soil developed in Unit II, supporting a slightly younger age for Unit III.

Numerous bore holes (Raba-Kistner Consultants, Inc., 1994) provide a baseline for lithological control for Unit III. B-18, B-5, B-4, and BHT-3 revealed a $2-4 \mathrm{~m}$ thick sequence of moderately well to somewhat poorly sorted and grainsupported channel cobbles (III-c) unconformably overlying Cretaceous shales (Figures 4 and 5). A veneer of loam (III-f) covers the Unit III-c cobbles where not disturbed by quarrying (Figure 5; B-18, B-5).

As pointed out earlier, Unit III-f deposits appear to have buried part of the T3/Unit II assemblage in the vicinity of H2U2 and BHT-12 (Figure 5, Component e; Appendix A). In BHT-12 the soil A horizon formed in Unit III-f deposits, which subsequently welded into the underlying $\mathrm{Bk}$ horizon that had previously formed in Unit II.
Apparently, the original A horizon of the Unit II soil was truncated prior to Unit III-f deposition. In the area of $\mathrm{H} 2 \mathrm{U} 2$, the $A$ horizon of the T3/Unit II soil was left intact during burial by Unit III-f. Here, Unit III-f was thick enough that an A-Bw soil profile has developed.

Channel cutbank A (Figure 5) shows an undisturbed section of Unit III that was deposited by a tributary entering Leon Creek from the southeast. The gravels are poorly sorted, lack imbrication, and are in part matrix supported. These properties indicate that deposition from some small tributaries of Leon Creek during this time was occurring as a mass of unsorted sediment flow, or hyperconcentrated flow (Miall 1978). However, facies relations in most areas of Unit III suggest that Leon Creek was a low sinuosity, graveliferous bedload stream at this time.

\section{Chronology}

Between 5000 and 3000 B.P. a brief period of channel erosion occurred in many streams throughout central Texas (Nordt 1992, 1995; Blum and Valastro 1989; Thoms and Mandel 1992). This erosional event may have also cut the valley that Unit III of Leon Creek later filled. As previously discussed, components containing points ranging from Early to Middle Archaic were found buried within the soil surface horizon between H2U2 and BHT-12. Accordingly, Unit III-f deposition was ongoing, and burying part of the T3/Unit II assemblage, sometime between 4000 and 1000 B.P.

As observed by Nordt $(1992,1995)$ along low order tributaries at Fort Hood, and by Blum and Valastro (1989) along the Pedernales River, late Holocene sediments that filled these newly cut late Holocene valleys were very graveliferous and similar to Unit III of Leon Creek. Nordt (1992) dated these late Holocene graveliferous deposits to between 4000 and 2000 B.P. (Lower West Range alluvium), while Blum and Valastro (1989) dated them to between 4000 and 1000 B.P. It is unknown whether the increase in gravelly channel bedload shortly after 5000 B.P. marked an increase in flood magnitudes and 
channel competency or whether there was simply a greater abundance of gravels being delivered to the tributary network. The latter could have occurred as thick Pleistocene soils were stripped down to the underlying basement rock within the early Holocene tributary network, even in the absence of a major climatic change (Blum and Valastro 1994; Nordt 1992, 1995).

Although fine-grained sedimentation was occurring along the Medina River during the late Holocene, deposition was rapid between about 4000 and 3000 B.P. This period of rapid deposition probably correlates with Unit III deposition along Leon Creek.

\section{UNIT IV}

\section{Lithology}

The T1/Unit IV assemblage forms an isolated flood terrace about 3.5- $4 \mathrm{~m}$ above the modern low-water channel of Leon Creek (Figures 4 and 5; B-B'). As revealed in BHT-A, the Unit IV-f facies has been altered to a weakly developed A$\mathrm{Bw}-\mathrm{Bk}$ sandy clay loam soil profile, ranging in color from black in the surface horizon to brown in the Bk horizon. The Bk horizon also has 1-2 percent filaments of $\mathrm{CaCO}_{3}$. Between a depth of 174 and $193 \mathrm{~cm}$ the Unit IV-c facies consists of a $0.5 \mathrm{~m}$ thick bed of moderately well sorted channel pebbles. Lithologically this indicates a shift in hydrological regime to a fine-grained meanderbelt sometime in the late Holocene, similar to the channel type that deposited Unit I in the late Pleistocene or early Holocene. However, it is also possible that Unit IV represents a neck-cutoff of Unit III, which subsequently filled with fine-grained sediment.

\section{Chronology}

The surface Marcos point identified in Unit III-f deposits indicates that Unit III deposition terminated around 2000 B.P. and deposition of Unit IV probably proceeded shortly thereafter. Nordt $(1992,1995)$ recognized a similar unit (with respect to lithology and degree of soil development) at Fort Hood as the Upper West Range alluvium that was deposited between about 2000 and 600 B.P. Unit IV deposition also appears to coincide with fine-grained flood aggradation and development of the Leon Creek paleosol between 3000 and 1500 B.P. along the Medina River (Thoms and Mandel 1992). If Unit IV is a neck cutoff of Unit III, then Units III and IV are facies-related, both of which could have been deposited between 4000 and 600 B.P.

\section{UNIT V}

Unit V is the modern floodplain alluvium, which consists mainly of gravel bars within the channel and gravel point bars immediately adjacent to the channel on the inside of modern meander bends (Figures 4 and 5; C-C'). As revealed in BHT-5, about $150 \mathrm{~cm}$ of moderately well sorted and grain-supported cobbles unconformably overlie Cretaceous shale. Relationships in B-8 show that the erosional base of the modern channel is cut about one meter below the Cretaceous shale that crops out immediately adjacent to the channel. Apparently, a brief period of channel erosion was followed by continued coarse-grained aggradation during the last few hundred years. Deposition of Unit V along Leon Creek correlates with the modern Ford alluvium at Fort Hood (Nordt 1992, 1995) and with the Modern floodplain unit along the Medina River (Thoms 1992), both of which were deposited during the last 500 years.

\section{GEOARCHAEOLOGY}

\section{UNIT I}

Unit $I$ is deeply buried beneath T4, appears to have been deposited by a fine-grained channel meanderbelt, and is older than 8800 B.P. (Figures 4 and 5). Consequently, Paleoindian sites may be buried, and preserved within a primary context, in Unit I. However, to date, no features or artifactual debris have been discovered. This may be in part because most of the soil that developed in the top of Unit I was truncated by channel activity during the Early to Middle Holocene. 


\section{UNIT II}

Unit II forms the constructional surface of both the T3 flood terrace and the T4 terrace (Figures 4 and 5). Rapid deposition of Unit II, and construction of T3 and T4, occurred between about 8500 and 5000 B.P. However, slow aggradation continued on the T3/Unit II assemblage in some areas until as late as 4000 to 2000 B.P. This is particularly evident near BHT12 and H2/U2. During deposition of Unit II, Leon Creek was a pebbly to cobbly bedload stream. Thick gravel bars (II-c) grade into chute channels (II-f) that were filled by fine-grained sediment as the trunk stream migrated from the vicinity of the T4/T3 scarp and toward the modern Leon Creek channel.

The large number of components discovered in the chute fills and floodbasin deposits of Unit II attest to site forming processes favorable for preservation in primary contexts. By 8500 to 7400 B.P., the trunk channel of Unit II had already migrated from the T4/T3 scarp to the vicinity of $\mathrm{H} 2 / \mathrm{U} 2$ and $\mathrm{BHT}-12$. Consequently, a large gravelly point bar with bar-ridges and chutes was available for occupation by this time. Prehistoric peoples constructed temporary camp sites directly on bar-ridges and in chute channels. As the meander loop of Unit II continued to migrate northward fine-grained material filled the chutes, covered the gravel bars, and buried the sites. These buried sites could range in age from late Paleoindian to Early Archaic. Based on a Uvalde point discovered at a depth of $46 \mathrm{~cm}$ in Component $\mathrm{c}$ and a carbon14 age of 5810 B.P. from the buried channel cutoff (Figure 5), the remaining components in the Unit T4/II-f assemblage should date to the latter part of the Early Archaic.

The surface of T4 may contain a mixed assemblage of sites spanning the Early Archaic to present. The same is true of T3 which is unaffected by middle and. late Holocene flood deposition or erosion. However, where late Holocene Unit III-f deposition buries the T3/Unit $\Pi$ assemblage, sites dating to no earlier than the Middle Archaic will be found on T3 in this area.
Interestingly, most of the Early Archaic components discovered in the current testing phase are buried within the upper $\mathrm{Bk}$ horizon of the surface soil of the T3/Unit II assemblage. Soil chronosequence studies show that steady state for soil organic matter accumulation can occur in as little as 50 to 100 years (Birkeland 1984). The absence of sediment darkening in the $\mathrm{Bk}$ horizon containing the buried sites indicates that alluvial aggradation was rapid, that there was no long-term living surface available for occupation, and that there was intense cultural occupation over a rather brief time interval.

\section{UNITS III and IV}

The numerical ages of the T2/Unit III and T1/Unit IV assemblages are unknown, but based on stratigraphic position and degree of soil development they must be younger than Unit II and therefore late Holocene. Unit III is tentatively thought to date between 4000 and 2000 B.P. and Unit IV between 2000 and 600 B.P.

Because Unit III consists mainly of gravelly bedload channel deposits (III-c), preservation potentials were probably lower than in Unit II. Furthermore, because of recent disturbance by quarrying activity it is unknown how much finegrained floodbasin deposition from Unit III-f originally covered the Unit III-c channel facies within the area of T2. As with Unit II, however, sites in Unit III could be buried on the contact between loamy floodbasin deposits and upper gravel bars in undisturbed areas.

In some areas, Unit III-f buries part of the T3/Unit II assemblage and the associated Early Archaic record as well. Where thick enough, Unit III-f potentially contains buried Middle Archaic to Late Archaic sites overlying Unit II within the area of both T2 and T3. Where tributary channels enter Leon Creek carrying a coarse-grained, and perhaps hyperconcentrated load, preservation potentials are low. 
Unit IV was deposited by a fine-grained meanderbelt or by filling of a Unit III channel neck cut-off. In either case preservation potentials in a primary context are high for Unit IV. This unit could contain portions of the Middle Archaic and late prehistoric records. The $\mathrm{T} 2$ and $\mathrm{T} 1$ surfaces may accordingly contain Middle Archaic to Historic sites.

\section{UNIT V}

Unit V is poorly defined and of limited extent. It consists mainly of active gravel bars associated with the modern channel. Current flood magnitudes do not appear to be great enough to carry a significant sediment load onto T3 and T4. However, minor deposition of modern finegrained flood material has undoubtedly occurred on $\mathrm{T} 2$ and $\mathrm{T} 1$. Preservation potentials are considered low for Unit V.

\section{CONCLUSIONS}

The late Quaternary stratigraphic record of Leon Creek conditions the spatial and temporal distribution of the archaeological record, while environments of deposition influence site forming processes and preservation potentials. Accordingly, the Paleoindian record will be deeply stratified within Units I and II, the Early Archaic record within the upper part of Unit II, and the Middle Archaic to Historic records within Units III, IV, and V. Preservation potentials will be greatest in floodbasin deposits of Units I-f, II-f and IV-f and in chute fills of Unit II-f.

The surfaces of T4 and T3 may contain sites spanning the Early Archaic to present. Where partially buried by Unit III-f, T3 will have surface sites no older than the Middle Archaic. The degree of disturbance in the area of $\mathrm{T} 2$ and $\mathrm{T} 1$ limits geoarchaeological interpretations, although undisturbed surfaces would contain sites dating to probably no older than the Middle Archaic.
The large number of Early Archaic components buried in the Bk horizon in the T3/Unit II assemblage demonstrates that geoarchaeological theories relating site densities to rates of aggradation (Ferring 1986) do not apply to this site. Typically sites are vertically superposed in rapidly aggrading environments, even during times when population densities are thought to be relatively high. Consequently, studying site forming processes along Leon Creek would elucidate and expand upon not only archaeological research, but geoarchaeological theories as well. 


\section{CHAPTER 4: RESULTS}

\section{FEATURE DESCRIPTIONS}

Seventy-nine burned rock features were identified and given feature numbers during the field phase of intensive testing at 41BX47. Four of these features actually contained more than one element, accounting for the 84 feature entries shown in Table 3. Four features $(1,30 \mathrm{a}$, $30 \mathrm{~b}, 48$, and 49) were discovered in three of the test units, the remaining 80 were uncovered in 35 of the 59 Gradall trenches. Based on size, shape, number of rocks, and degree of fracturing, these feature were classified into four informal types during the fieldwork.

1) middens $(n=3)$ which are large, dense, irregularly shaped concentrations of heavily cracked burned rock;

2) ovens $(n=2)$ which are oval, multilayered, accumulations of large, slightly cracked and uncracked burned rock;

3) small hearths $(n=57)$ which are composed of lightly cracked and uncracked burned rock; and

4) scatters $(n=22)$ which are amorphous low density distributions of burned rock.

Artifacts were found in direct association with $\mathbf{5 5}$ of the 84 features. The following descriptions are based on limited exposure of upper portions of features, as this testing phase of investigation was designed to locate not excavate features.

\section{BURNED-ROCK MIDDEN FEATURES}

Large, burned rock midden features were uncovered in three trenches. The features are large, horizontally and vertically discrete, dense accumulations of angularly fractured, heavily burned limestone that appear similar to burned rock middens frequently found in Middle
Archaic deposits in south central Texas (Black 1989; Collins 1991; Weir 1976).

Feature 9, in trench $H 1 M 1 / G 1$ in the west section of the site, represents one burned rock midden referred to as the western midden in this report (see Figures 2 and 3). The portion of this midden visible in trench $\mathrm{H} 1 \mathrm{M} 1 / \mathrm{G} 1$ and test unit $\mathrm{H} 1 / \mathrm{U} 1$ is $1.6 \mathrm{~m}$ long and $1.7 \mathrm{~m}$ wide.

Feature 23, in trench $\mathrm{H}_{2} / \mathrm{G} 2$, and Feature 25, in trench $\mathrm{H} 2 / \mathrm{G} 3$ represent the second burned rock midden accumulation at the site. These features are located in trenches $10 \mathrm{~m}$ apart in the north section of the site (see Figures 2 and 3). Similar burned-rock deposits found in trenches $\mathrm{M} 2 / \mathrm{G} 1$ and $\mathrm{M} 2 / \mathrm{G} 2$ and test unit M2/U1, just west of Features 23 and 25 , and in test units $\mathrm{H} 2 / \mathrm{U}$ and $\mathrm{H} 2 / \mathrm{U}$ to the south were not assigned feature numbers as they are thought to be a continuation of this northern burned rock midden. Based on these exposed portion, we estimate this northern midden extends over an area roughly $50 \times 30 \mathrm{~m}$.

Both of these dense burned-rock accumulations are composed of over 200 rocks which vary in size from $5-20 \mathrm{~cm}$. The rocks appear to be in matrix-supported layers without discernable patterning, although some evidence of crackingin-place is present. Both of these burned-rock deposits were encountered in the top $30 \mathrm{~cm}$ of the dark brown A horizon. While these features were not excavated, evidence from test units adjacent to the trenches suggest they are shallow deposits with a maximum thickness of approximately $20-30 \mathrm{~cm}$. and appear to rest directly above a heavily graveled caliche layer .

Seven identifiable diagnostic points and one unknown type were recovered from the Gradall trench fill dirt associated with the northern midden feature. These include one Bulverde, three Pedernales, and two Kinney from the Middle Archaic, and one Late Archaic Marcos. One other Middle Archaic point, a Kinney and a 
Table 3. List of Features

\begin{tabular}{|c|c|c|c|c|c|c|c|c|c|}
\hline \multirow[t]{2}{*}{ Ftr } & \multirow[t]{2}{*}{ Location } & \multirow{2}{*}{$\begin{array}{l}\text { Depth } \\
\mathrm{cm} \text { bs }\end{array}$} & \multicolumn{2}{|c|}{ Dimensions $\mathrm{cm}$} & \multirow[t]{2}{*}{ Type } & \multirow[t]{2}{*}{ \# Rocks } & \multirow[t]{2}{*}{ Shape } & \multirow[t]{2}{*}{ Conjoins } & \multirow[t]{2}{*}{ Artifac } \\
\hline & & & $\mathrm{E} / \mathrm{W}$ & $\mathrm{N} / \mathrm{S}$ & & & & & \\
\hline 1 & M3/U2 & 40 & 19 & 21 & hearth & 11 & $\mathrm{Cir}$ & $\mathbf{N}$ & $\mathrm{Y}$ \\
\hline 2 & L6/G1 & 54 & 40 & 50 & hearth & 13 & Oval & $\mathrm{N}$ & $Y$ \\
\hline 3 & L6/G1 & 54 & 50 & 40 & hearth & 8 & Cir & $\mathrm{N}$ & $\mathrm{N}$ \\
\hline 4 & M3/G1 & 44 & 52 & 39 & hearth & 12 & Oval & $Y$ & $\mathrm{~N}$ \\
\hline 5 & M1L3/G1 & 36 & 65 & 70 & hearth & 25 & Cir & $\mathrm{Y}$ & $\mathrm{N}$ \\
\hline 6 & L6/G1 & 38 & 27 & 26 & hearth & 8 & $\mathrm{Cir}$ & $\mathrm{Y}$ & $\mathrm{N}$ \\
\hline 7 & L6/G1 & 45 & 30 & *profile & hearth & 4 & $?$ & $?$ & $\mathrm{~N}$ \\
\hline 8 & $\mathrm{H} 1 / \mathrm{G} 1$ & 20 & 100 & 100 & hearth & 50 & Cir & $\mathrm{Y}$ & $\mathrm{N}$ \\
\hline 9 & H1M1/G1 & 16 & $* 130$ & *900 & midden & $200+$ & Irr & $\mathrm{Y}$ & $\mathrm{N}$ \\
\hline 10 & $\mathrm{H} 1 \mathrm{M} 1 / \mathrm{G} 1$ & 46 & *80 & 120 & oven & 47 & Oval & $\mathrm{Y}$ & $\mathrm{N}$ \\
\hline 11 & H3/G1 & 32 & 41 & 47 & hearth & 12 & Oval & $\mathrm{N}$ & $\mathrm{N}$ \\
\hline 12 & $\mathrm{H} 3 / \mathrm{G} 1$ & 42 & 23 & 34 & hearth & 5 & Semicir & $\mathrm{N}$ & $Y$ \\
\hline 13 & $\mathrm{H} 3 / \mathrm{G} 1$ & 36 & 42 & 55 & hearth & 9 & Semicir & $\mathrm{N}$ & $\mathrm{Y}$ \\
\hline 14 & $\mathrm{G} / \mathrm{T} 2$ & 65 & 87 & 68 & scatter & 14 & Irr & $N$ & $\mathrm{~N}$ \\
\hline 15 & $\mathrm{H} 2 / \mathrm{G} 1$ & 113 & 28 & 52 & hearth & 15 & Oval & $N$ & $\mathrm{~N}$ \\
\hline 16 & $\mathrm{H} 2 / \mathrm{G} 1$ & 80 & 40 & 40 & hearth & 19 & $\mathrm{Cir}$ & $\mathrm{Y}$ & $\mathrm{N}$ \\
\hline $17 \mathrm{a}$ & $\mathrm{H} 2 / \mathrm{G} 1$ & 85 & 140 & 85 & scatter & 29 & Irr & $\mathrm{N}$ & $\mathrm{Y}$ \\
\hline $17 b$ & $\mathrm{H} 2 / \mathrm{G} 1$ & 79 & 50 & 60 & hearth & 19 & $\mathrm{Cir}$ & $\mathrm{N}$ & $\mathrm{Y}$ \\
\hline $17 c$ & $\mathrm{H} 2 / \mathrm{G} 1$ & 80 & 80 & 60 & hearth & 26 & Cir & $\mathrm{N}$ & $\mathrm{Y}$ \\
\hline $17 d$ & $\mathrm{H} 2 / \mathrm{G} 1$ & 87 & 80 & 60 & hearth & 34 & Cir & $N$ & $\mathrm{Y}$ \\
\hline $18 \mathrm{a}$ & $\mathrm{H} 2 / \mathrm{G} 1$ & 62 & $* 15$ & 33 & hearth & 9 & Cir & $\mathrm{Y}$ & $\mathrm{Y}$ \\
\hline $18 b$ & $\mathrm{H} 2 / \mathrm{G} 1$ & 74 & $* 25$ & 25 & hearth & 8 & $\mathrm{Cir}$ & $\mathrm{Y}$ & $\mathrm{Y}$ \\
\hline 19 & $\mathrm{H} 2 / \mathrm{G} 1$ & 55 & *80 & 124 & scatter & 66 & Irr & $\mathrm{Y}$ & $\mathrm{Y}$ \\
\hline $20 \mathrm{a}$ & $\mathrm{H} 2 / \mathrm{G} 1$ & 61 & 36 & 40 & hearth & 13 & $\mathrm{Cir}$ & $N$ & $\mathrm{Y}$ \\
\hline $20 b$ & $\mathrm{H} 2 / \mathrm{G} 1$ & 61 & 24 & 25 & hearth & 14 & Cir & $\mathrm{Y}$ & $\mathrm{Y}$ \\
\hline 21 & $\mathrm{H} 2 / \mathrm{G} 1$ & 68 & 45 & 50 & hearth & 17 & Cir & $\mathrm{Y}$ & $\mathrm{Y}$ \\
\hline 22 & $\mathrm{~L} 4 / \mathrm{G} 1$ & 100 & 50 & 90 & scatter & 7 & Semicir & $\mathrm{N}$ & $Y$ \\
\hline 23 & $\mathrm{H} 2 / \mathrm{G} 2$ & 25 & $* 170$ & $* 560$ & midden & $200+$ & Irr & $\mathrm{Y}$ & $\mathrm{Y}$ \\
\hline 24 & $\mathrm{H} 2 / \mathrm{G} 3$ & 24 & $* 170$ & 120 & scatter & $100+$ & Irr & $\mathrm{N}$ & $\mathrm{Y}$ \\
\hline 25 & $\mathrm{H} 2 / \mathrm{G} 3$ & 30 & $* 67$ & $* 160$ & midden & $200+$ & Irr & $\mathrm{N}$ & $\mathrm{Y}$ \\
\hline 26 & $\mathrm{M} 2 / \mathrm{G} 2$ & 26 & 70 & 60 & hearth & 13 & Cir & $\mathrm{N}$ & $\mathrm{Y}$ \\
\hline 27 & L6/G4 & 31 & *93 & 240 & scatter & 54 & Scatter & $\mathrm{Y}$ & $\mathrm{Y}$ \\
\hline 28 & L6/G4 & 30 & 60 & 73 & scatter & 30 & Oval & $N$ & $Y$ \\
\hline 29 & L6/G4 & 36 & 70 & 60 & hearth & 17 & Oval & $\mathrm{N}$ & $\mathrm{Y}$ \\
\hline $30 a$ & $\mathrm{H} 2 / \mathrm{U} 2$ & 125 & 55 & $* 32$ & hearth & 12 & $\mathrm{Cir}$ & $\mathrm{Y}$ & $\mathrm{Y}$ \\
\hline $30 b$ & $\mathrm{H} 2 / \mathrm{U} 2$ & 125 & 52 & $* 28$ & hearth & 12 & Cir & $\mathrm{Y}$ & $\mathrm{Y}$ \\
\hline 31 & $L 6 / G 7$ & 53 & 40 & 55 & scatter & 10 & Rect & $\mathrm{Y}$ & $Y$ \\
\hline 32 & L6/G7 & 50 & 60 & 60 & hearth & 13 & Oval & $Y$ & $\mathrm{Y}$ \\
\hline 33 & $\mathrm{~L} 1 / \mathrm{G} 1$ & 58 & 60 & 60 & hearth & 14 & $\mathrm{Cir}$ & $\mathrm{N}$ & $\mathrm{N}$ \\
\hline 34 & $\mathrm{~L} 1 / \mathrm{G} 1$ & 68 & 40 & 36 & scatter & 3 & Semicir & $\mathbf{N}$ & $\mathrm{Y}$ \\
\hline 35 & $\mathrm{~L} 1 / \mathrm{G} 1$ & 47 & 45 & 37 & hearth & 8 & Cir & $\mathrm{N}$ & $\mathrm{N}$ \\
\hline 36 & $\mathrm{~L} 1 / \mathrm{G} 1$ & 60 & 90 & 90 & scatter & 11 & Scatter & $\mathrm{Y}$ & $\mathrm{Y}$ \\
\hline 37 & $F / G 1$ & 54 & 60 & $* 40$ & hearth & 15 & Semicir & $N$ & $\mathrm{~N}$ \\
\hline 38 & $\mathrm{~F} / \mathrm{G} 1$ & 44 & 148 & 40 & hearth & 28 & $\mathrm{Cir}$ & $Y$ & $\mathrm{Y}$ \\
\hline
\end{tabular}


Table 3. continued

\begin{tabular}{|c|c|c|c|c|c|c|c|c|c|}
\hline \multirow[t]{2}{*}{ Ftr } & \multirow[t]{2}{*}{ Location } & \multirow{2}{*}{$\begin{array}{l}\text { Depth } \\
\text { cm bs }\end{array}$} & \multicolumn{2}{|c|}{ Dimensions cm } & \multirow[t]{2}{*}{ Type } & \multirow[t]{2}{*}{ \# Rocks } & \multirow[t]{2}{*}{ Shape } & \multirow[t]{2}{*}{ Conjoins } & \multirow[t]{2}{*}{ Artifacts } \\
\hline & & & $E / W$ & $\mathrm{~N} / \mathrm{S}$ & & & & & \\
\hline 39 & $\mathrm{~F} / \mathrm{G} 1$ & 53 & 50 & $* 38$ & hearth & 17 & Cir & $\mathrm{N}$ & $\mathrm{N}$ \\
\hline 40 & $\mathrm{~F} / \mathrm{G} 5$ & 47 & 260 & $* 140$ & scatter & 53 & Scatter & $\mathrm{Y}$ & $\mathrm{Y}$ \\
\hline 41 & F/G5 & 38 & 40 & $* 70$ & scatter & 19 & Linear & $\mathrm{N}$ & $\mathrm{N}$ \\
\hline 42 & F/G5 & 38 & 41 & $* 32$ & hearth & 6 & $\mathrm{Cir}$ & $\mathrm{N}$ & $\mathrm{N}$ \\
\hline 43 & F/G5 & 42 & 70 & 70 & hearth & 19 & Cir & $\mathrm{N}$ & $\mathrm{N}$ \\
\hline 44 & $\mathrm{~F} / \mathrm{G} 4$ & 55 & 100 & $* 100$ & hearth & 53 & Semicir & $\mathrm{Y}$ & $\mathrm{N}$ \\
\hline 45 & F/G7 & 73 & 30 & 30 & hearth & 4 & Semicir & $N$ & $\mathrm{~N}$ \\
\hline 46 & F/G6 & 42 & 100 & 100 & hearth & 40 & Cir & $Y$ & $\mathrm{Y}$ \\
\hline 47 & F/G9 & 46 & 68 & 60 & scatter & 13 & Irr & $\mathrm{N}$ & $\mathrm{N}$ \\
\hline 48 & $\mathrm{M} 1 / \mathrm{U} 2$ & 51 & 58 & 56 & hearth & 7 & $\mathrm{Cir}$ & $\mathrm{N}$ & $\mathrm{N}$ \\
\hline 49 & $\mathrm{H} 2 / \mathrm{U} 2$ & 170 & $* 100$ & $* 100$ & hearth & 51 & Cir & $Y$ & $N$ \\
\hline 50 & L6/G8 & 53 & 69 & $* 39$ & hearth & 29 & Oval & $\mathrm{Y}$ & $\mathrm{Y}$ \\
\hline 51 & L6/G8 & 55 & 110 & $* 52$ & hearth & 20 & Semicir & $\mathrm{N}$ & $\mathrm{N}$ \\
\hline 52 & $\mathrm{~L} 6 / \mathrm{G} 8$ & 51 & 120 & $* 58$ & hearth & 25 & $\mathrm{Cir}$ & $\mathrm{Y}$ & $\mathrm{Y}$ \\
\hline 53 & L6/G8 & 56 & 48 & 56 & scatter & 10 & Irr & $\mathrm{N}$ & $\mathrm{Y}$ \\
\hline 54 & L6/G8 & 62 & 40 & 31 & scatter & 5 & Irr & $N$ & $\mathrm{~N}$ \\
\hline 55 & L6/G8 & 50 & 70 & 50 & scatter & 26 & Cir & $\mathrm{N}$ & $\mathrm{Y}$ \\
\hline 56 & L6/G8 & 53 & 57 & 123 & hearth & 40 & Oval & $\mathrm{Y}$ & $\mathrm{Y}$ \\
\hline 57 & $F G / 11$ & 53 & 170 & $* 170$ & oven & 82 & $\mathrm{Cir}$ & $\mathrm{Y}$ & $\mathrm{Y}$ \\
\hline 58 & $\mathrm{FG} / 11$ & 53 & 68 & 125 & hearth & 26 & Oval & $Y$ & $N$ \\
\hline 59 & L6/G10 & 46 & 64 & 41 & hearth & 22 & Cir & $\mathrm{N}$ & $\mathrm{Y}$ \\
\hline 60 & L6/G11 & 27 & 94 & $* 102$ & hearth & 61 & Cir & $\mathrm{Y}$ & $\mathrm{Y}$ \\
\hline 61 & L6/G11 & 32 & 56 & 54 & hearth & 48 & $\mathrm{Cir}$ & $\mathrm{Y}$ & $\mathrm{Y}$ \\
\hline 62 & L6/G11 & 48 & 150 & 150 & scatter & 45 & Irr & $N$ & $\mathrm{Y}$ \\
\hline 63 & L6/G11 & 40 & 120 & 100 & hearth & 51 & Cir & $\mathrm{N}$ & $\mathrm{Y}$ \\
\hline 64 & L6/G11 & 30 & 50 & $* 15$ & hearth & 9 & Semicir & $\mathrm{N}$ & $Y$ \\
\hline 65 & L6/G11 & 40 & 55 & $* 12$ & hearth & 9 & Semicir & $\mathrm{N}$ & $\mathrm{N}$ \\
\hline 66 & F/G15 & 72 & 85 & 126 & hearth & 32 & Semicir & $\mathrm{Y}$ & $\mathrm{Y}$ \\
\hline 67 & F/G15 & 46 & 84 & 64 & hearth & 23 & Cir & $\mathrm{Y}$ & $\mathrm{Y}$ \\
\hline 68 & F/G15 & 60 & 60 & 50 & hearth & 34 & Cir & $\mathrm{Y}$ & $\mathrm{N}$ \\
\hline 69 & F/G17 & 44 & 30 & $* 40$ & scatter & 7 & Irr & $\mathrm{N}$ & $Y$ \\
\hline 70 & F/G16 & 51 & 100 & 78 & scatter & 18 & Irr & $Y$ & $\mathrm{Y}$ \\
\hline 71 & F/G16 & 32 & 47 & 65 & hearth & 10 & Cir & $\mathrm{N}$ & $\mathrm{Y}$ \\
\hline 72 & F/G16 & 44 & 106 & 40 & scatter & 8 & Irr & $\mathrm{Y}$ & $\mathrm{Y}$ \\
\hline 73 & F/G16 & 45 & 140 & $* 100$ & hearth & 31 & Cir & $\mathrm{Y}$ & $\mathrm{Y}$ \\
\hline 74 & $\mathrm{~L} 1 / \mathrm{G} 2$ & 78 & 100 & $* 40$ & hearth & 23 & Oval & $N$ & $N$ \\
\hline 75 & $\mathrm{~F} / \mathrm{G} 20$ & 72 & 125 & $* 115$ & scatter & 16 & Semicir & $Y$ & $\mathrm{Y}$ \\
\hline 76 & $\mathrm{~F} / \mathrm{G} 20$ & 59 & 46 & $* 27$ & hearth & 9 & Semicir & $\mathrm{N}$ & $\mathrm{N}$ \\
\hline 77 & $\mathrm{~F} / \mathrm{G} 21$ & 49 & 67 & 62 & scatter & 6 & Irr & $\mathrm{Y}$ & $\mathrm{Y}$ \\
\hline 78 & $\mathrm{~F} / \mathrm{G} 21$ & 51 & 43 & 45 & hearth & 5 & Semicir & $\mathrm{N}$ & $\mathrm{N}$ \\
\hline
\end{tabular}

* indicates incomplete dimensions for features not fully exposed in trench 
Late Archaic Marcos, were also discovered in the upper $20 \mathrm{~cm}$ of two test units in the northern portion of the site. Although no diagnostic points were found in direct association with the western midden deposit, one Marcos point was recovered from the surface at the southwest edge of H1M1/G1 where the western midden was exposed. One Bulverde, two Pedernales, and one Pandora were also found in Gradall fill dirt from nearby trenches M1L3/G1 and F/G21 located 40 $\mathrm{m}$ and $50 \mathrm{~m}$ respectively from Feature 9 . Based on these diagnostic points, the burned-rock midden deposits can be assigned to the Middle and Late Archaic periods.

\section{OVEN FEATURES}

Two clusters of lightly cracked and uncracked rock were found in two trenches. These circular features are similar to the rock ovens described by Johnson (1991) and Collins et al. (1990). Although the term oven has functional implications, it is used here only to denote physical differences in feature size and morphology. Feature 10 is located $46 \mathrm{~cm}$ bs in trench H1M1/G1. It is approximately $1 \mathrm{~m}$ south and $30 \mathrm{~cm}$ lower than Feature 9, the western midden deposit located in that same trench. Forty-seven lightly burned rocks comprise the exposed portion of this feature which remains partially concealed in the east wall of the trench (Figure 6). The rocks appear to be placed on top of one another forming an oval-shaped, domed cluster which measures $80 \times 120 \mathrm{~cm}$. At least four layers of rock are visible in portions of the feature and some conjoins are evident. The maximum dimensions of the rocks varies from 5-30 cm, with the larger rocks at the bottom. No artifacts were found with this feature.

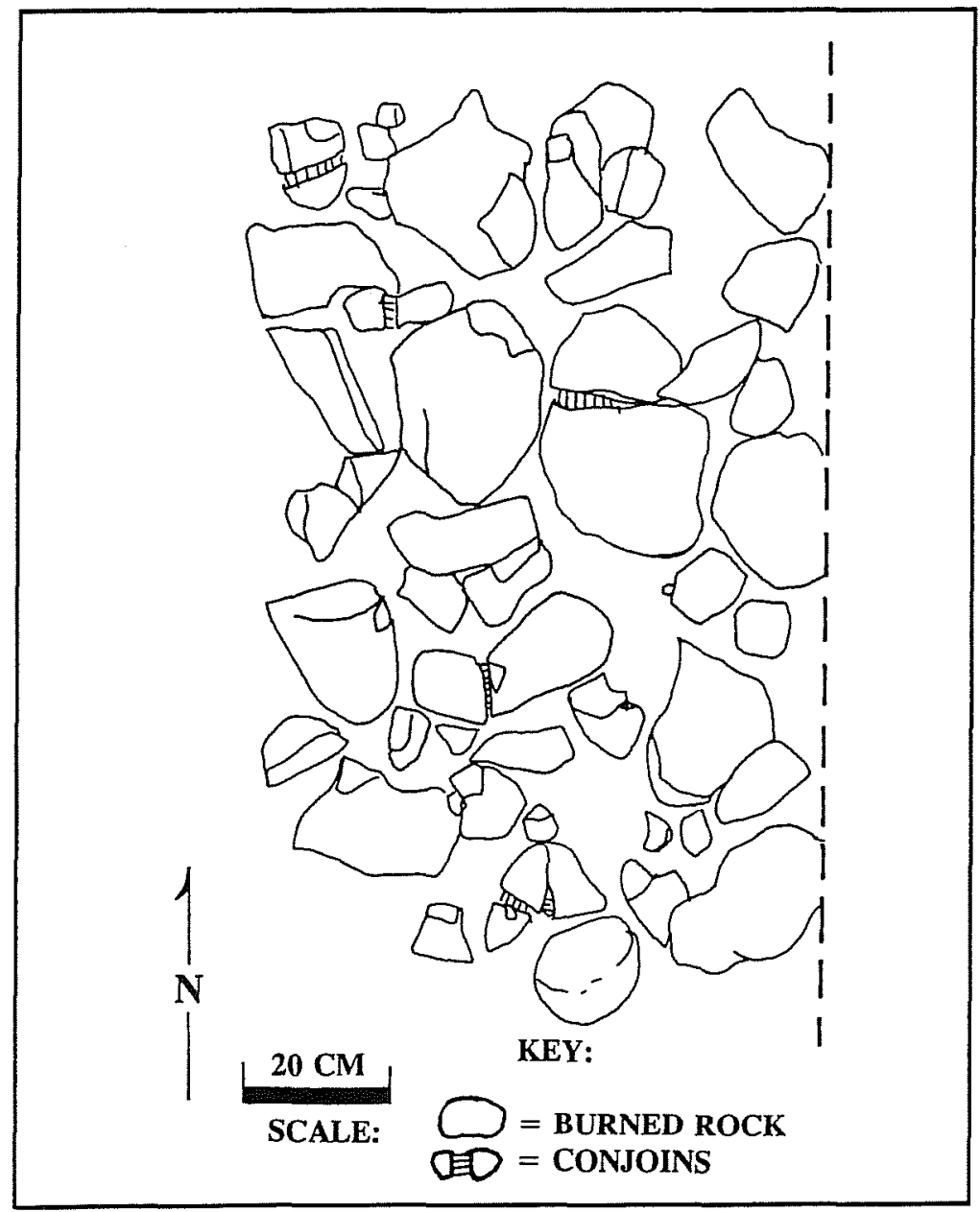

Figure 6. Feature 10. 
Feature $\mathbf{5 7}$ is located on the east side of the site in trench F/G11. This circular feature (Figure 7) is almost completely exposed in the trench and measures $170 \mathrm{~cm}$ in diameter. Like Feature 10 , Feature 57 is composed of large rocks (10-35 $\mathrm{cm}$ across) that show little evidence of burning although some conjoins are present. Two layers of rock are visible from the top of the feature, exposing a total of 82 rocks. This feature is located $53 \mathrm{~cm}$ bs in the B horizon. Four chert flakes but no diagnostics were found in situ with this feature.

\section{HEARTH FEATURES}

Fifty-seven intact hearth features were discovered in three of the test units and 24 of the Gradall trenches excavated at $41 B X 47$. They occur at depths ranging from $20-170 \mathrm{~cm}$ bs, and appear as single layers of lightly cracked and uncracked burned rock in flat, horizontal arrangements. The number of rocks in each hearth varies from 4-61 and the maximum dimensions for completely exposed hearths ranges from $21-126 \mathrm{~cm}$. Hearths are configured

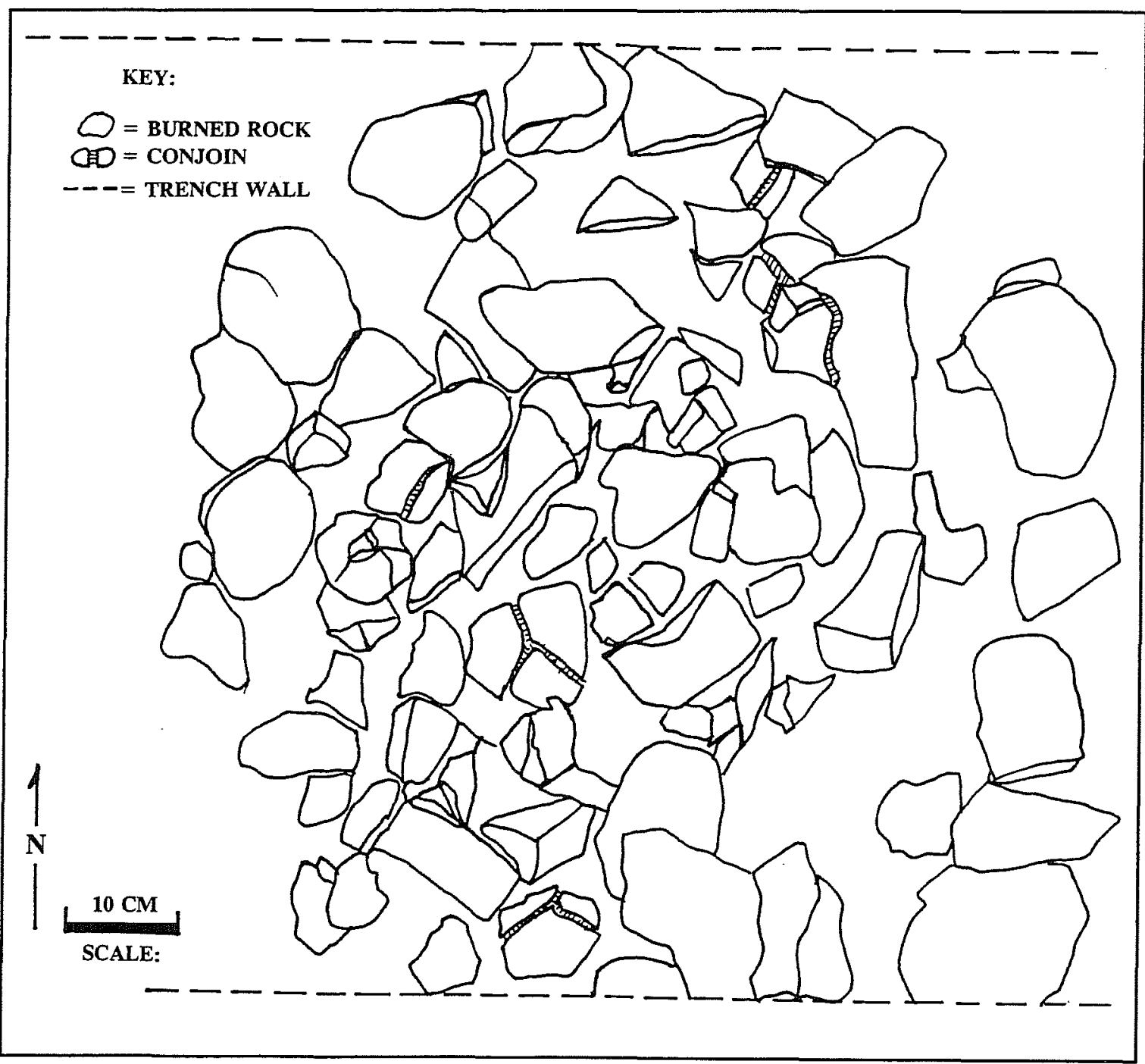

Figure 7. Feature 57. 
in a variety of shapes including circular, semicircular, and oval. Artifacts were recovered in situ in and around 34 of these hearth features. Recorded information from all hearth features is shown in Table 2. Seven examples of this feature type are described and illustrated below. Dotted lines in the illustrations indicate where trench or unit walls partially obscure feature detail.

Feature 16 (Figure 8) is located $80 \mathrm{~cm}$ bs in trench $\mathrm{H} 2 / \mathrm{G} 1$ in the northern section of the site within the T3 terrace. It is composed of 17 cracked and 2 uncracked burned rocks ranging in size from $3-15 \mathrm{~cm}$. The rocks are arranged in a solid, circular pattern that is $40 \mathrm{~cm}$ in diameter and appears to be one layer thick. No artifacts were found directly associated with this hearth but were found with the other 10 features in this trench.

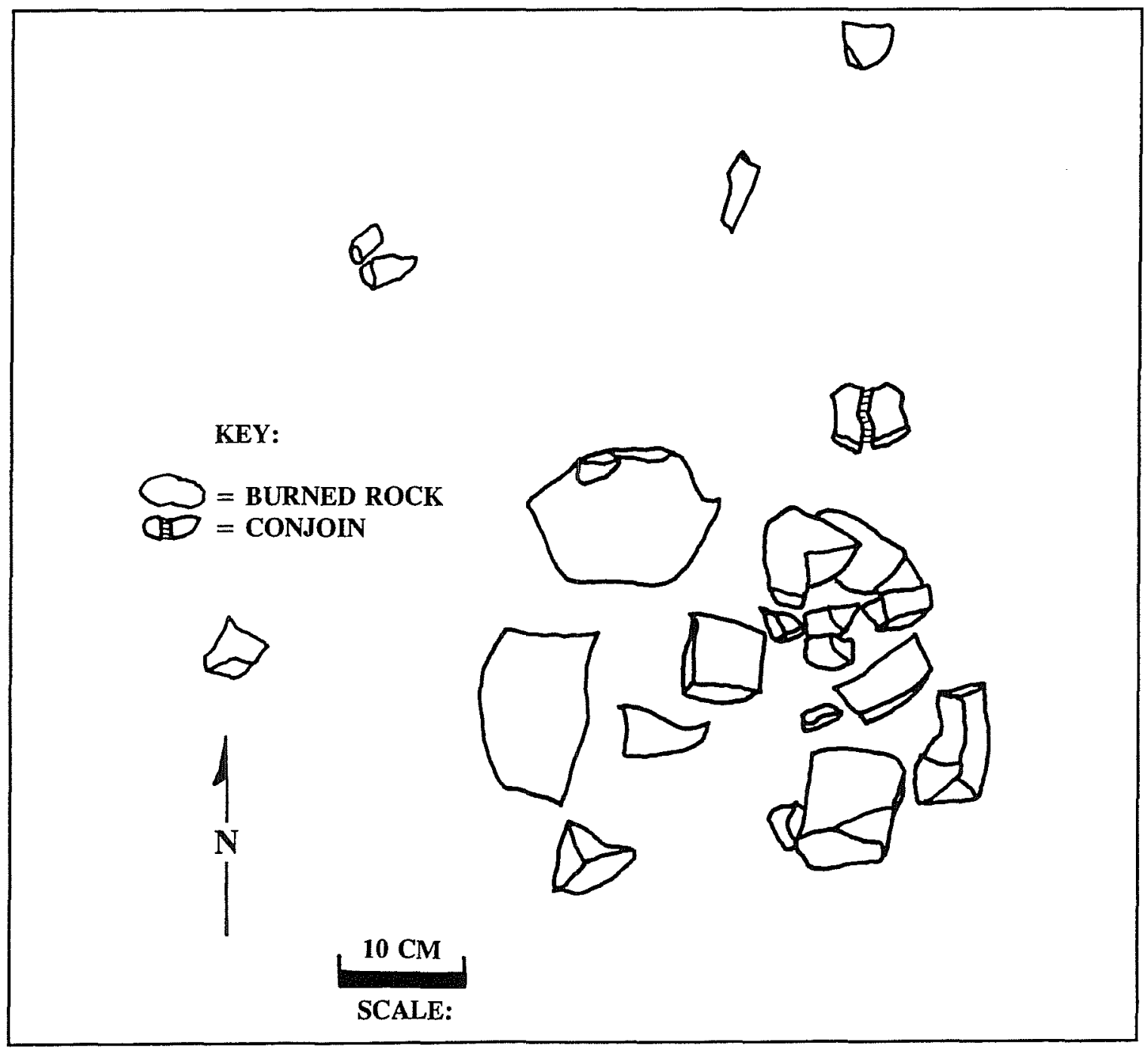

Figure 8. Feature 16. 
Feature 33 (Figure 9) is one of 5 features uncovered in trench L1/G1 in the west portion of the site on the T4 terrace. It is located $58 \mathrm{~cm}$ bs. Twelve cracked and two uncracked burned rocksform a circular outline that is one layer thick and measures $60 \mathrm{~cm}$ in diameter. The maximum dimension of the burned rocks in this hearth varies from 6-12 cm.
Feature 42 (Figure 10) is located in the T3 terrace in the southwest portion of the site, 38 $\mathrm{cm}$ bs in trench F/G5. This hearth feature contains six fire-cracked rocks between $8-20 \mathrm{~cm}$ in length, and is $41 \times 32 \mathrm{~cm}$ across. This single layer of rock is arranged in a circular pattern and slopes slightly toward the center. No artifacts were found with this or any of the other three features in this trench.

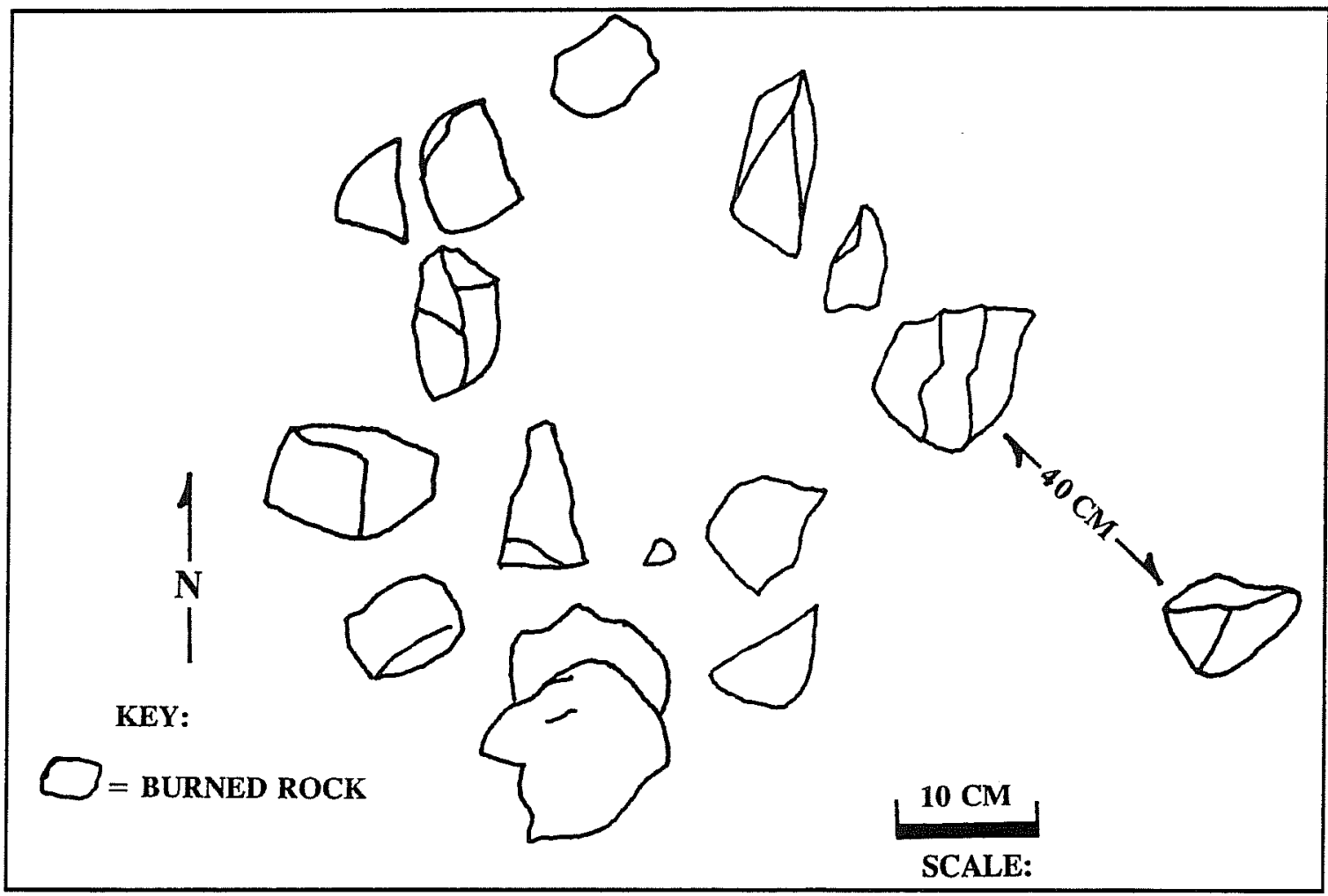

Figure 9. Feature 33.

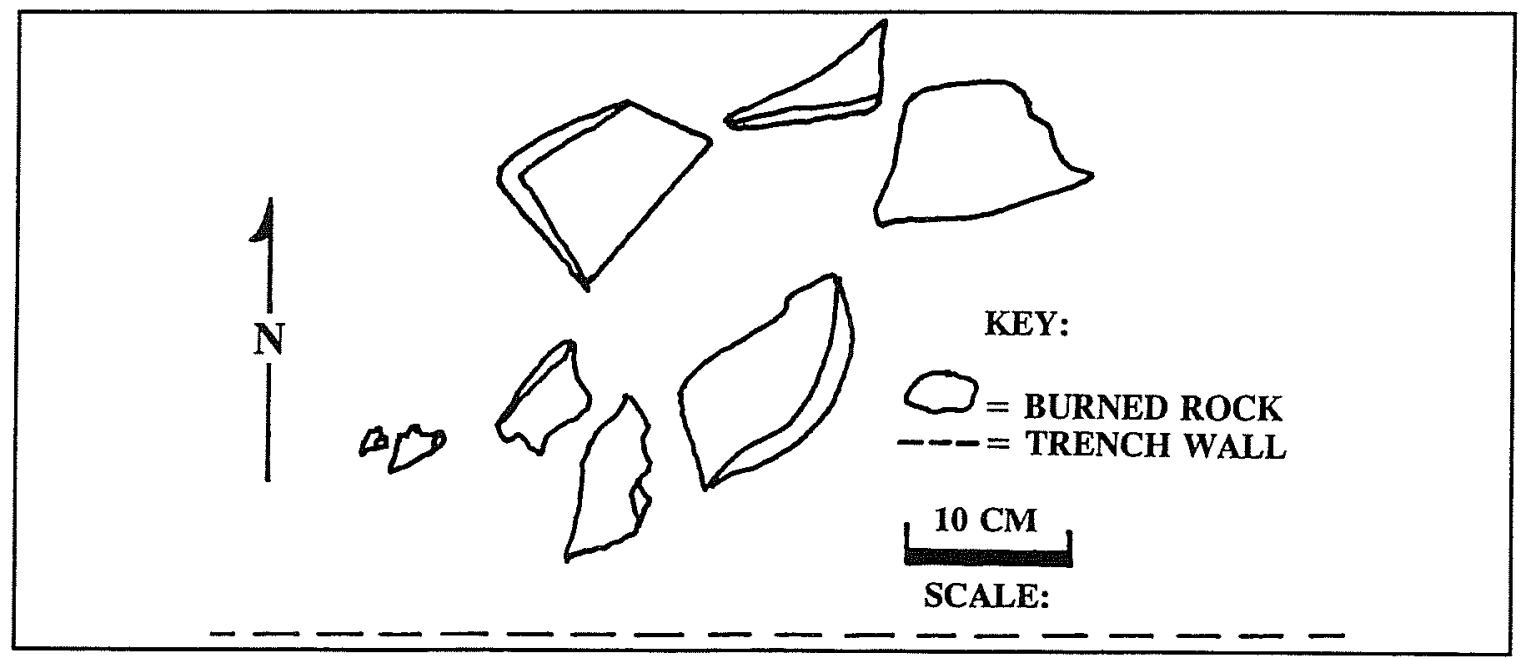

Figure 10. Feature 42. 
Feature 44 is the only feature discovered in trench F/G4. It is located $55 \mathrm{~cm}$ bs and contains 53 burned rocks, many of which show evidence of cooling in place (Figure 11). This hearth is arranged in a semicircle measuring one meter at the widest point. A $50-\mathrm{x}-50-\mathrm{cm}$ section of
Feature 44 was excavated, revealing a single layer of rock except along the southwest edge where two layers of rock were placed one on top of the other. The rocks slope slightly downward on the west side but no pit outline was evident in profile.

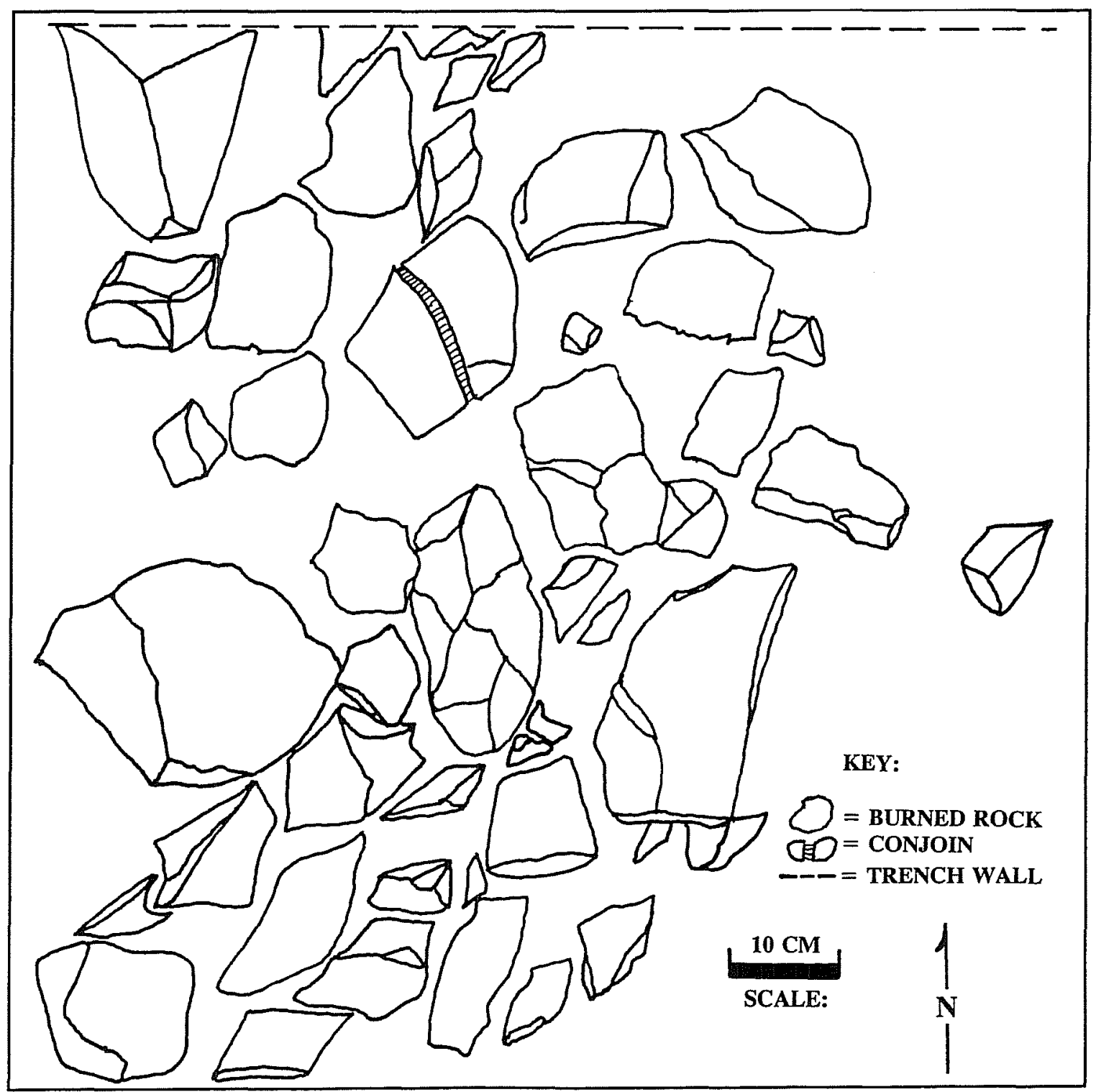

Figure 11. Feature 44. 
Feature 67 is one of three features exposed in trench F/G15 within the T4 terrace on the east side of the site. This feature is composed of 23 burned rocks that are between 6 and $15 \mathrm{~cm}$ in size. The rocks appear to slope toward the center of three separate clusters, suggesting three small hearths within this $85-\mathrm{x}-64-\mathrm{cm}$ feature (Figure 12). Three tertiary flakes were uncovered in situ within this feature.

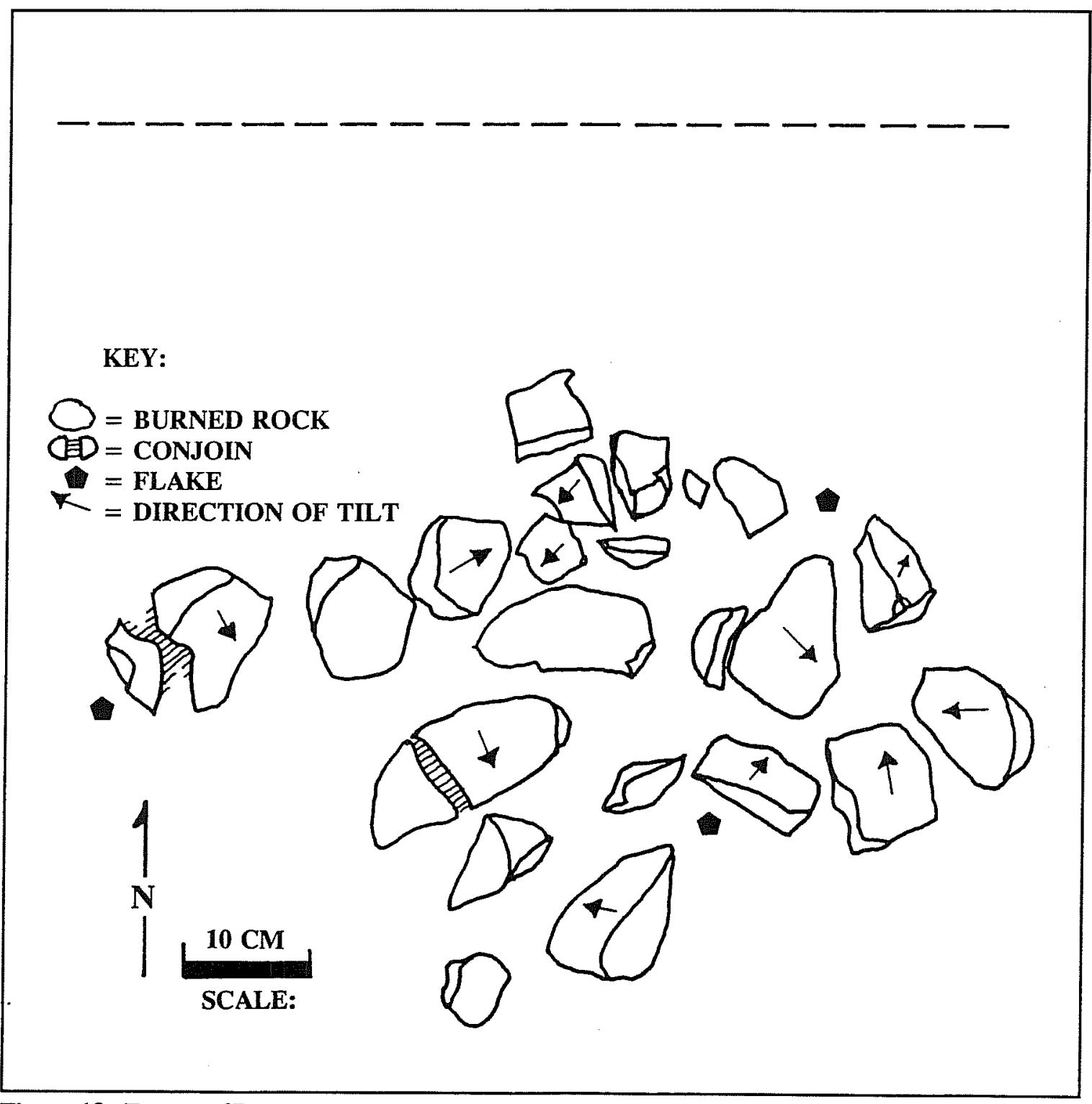

Figure 12. Feature 67. 
The following two features were uncovered during hand excavation of test unit $\mathrm{H} 2 / \mathrm{U} 2$ in the northern section of the site.

Feature 30 consists of two hearths discovered $125 \mathrm{~cm}$ bs in test unit H2/U2 (Figure 13). The hearths are located $50 \mathrm{~cm}$ apart with one, 30a, almost completely exposed in the northwest corner of the unit, the other, 30b, almost completely exposed in the southeast corner of the unit. Both contain 12 lightly cracked or uncracked burned rocks measuring $5-15 \mathrm{~cm}$ across. Both hearths are circular and consist of a single layer of rock. No pit outline was visible in the profile around either hearth. The base of an Angostura point was recovered in situ $20 \mathrm{~cm}$ south of $30 \mathrm{a}$ and $14 \mathrm{~cm}$ north of $30 \mathrm{~b}$. Ninetyseven chert flakes were also recovered from the 10-cm level containing Feature 30.

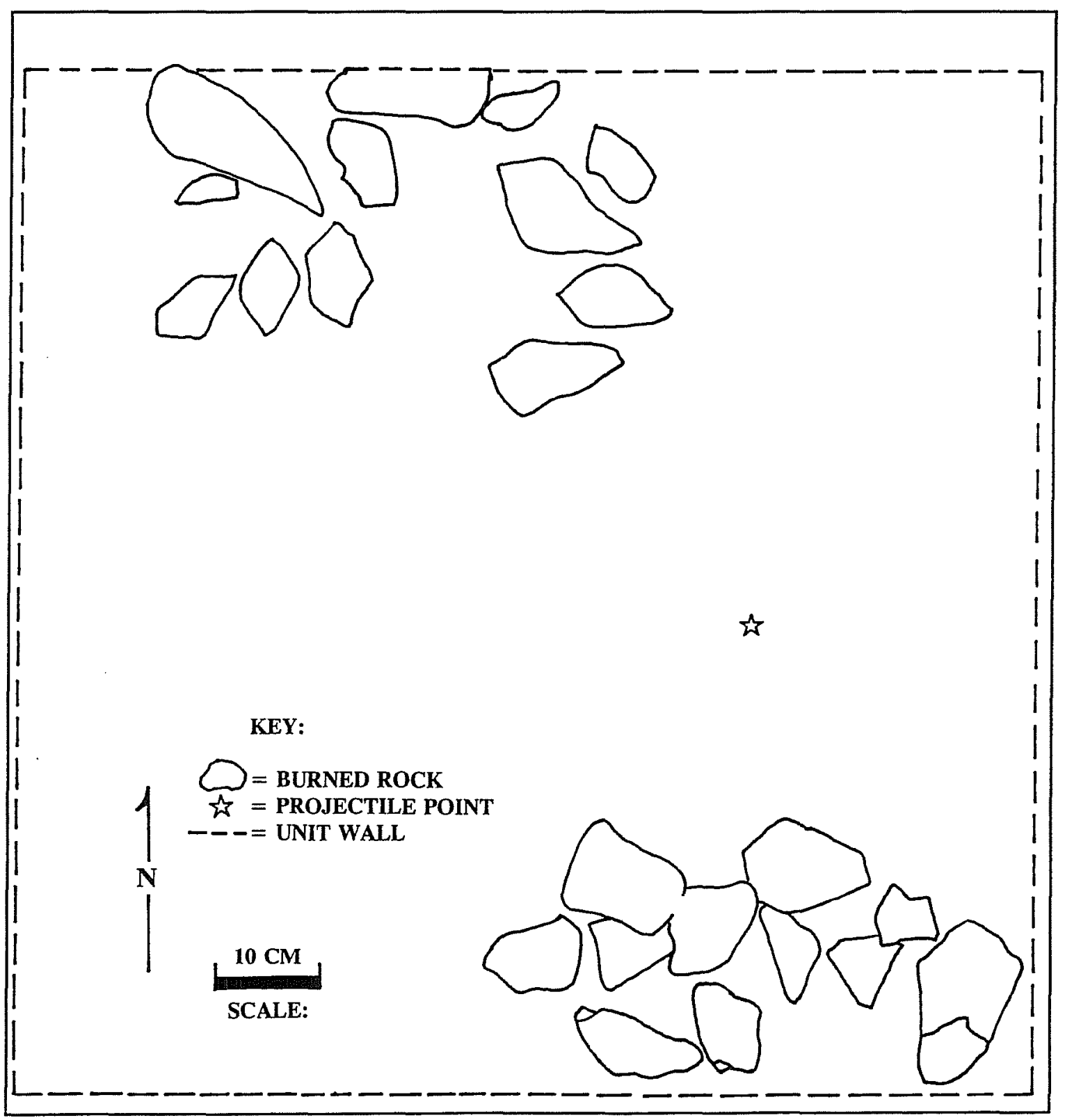

Figure 13. Feature 30. 
Feature 49 is located $45 \mathrm{~cm}$ below Feature 30 at $170 \mathrm{~cm}$ bs in unit H2/U2. It appears to continue into the north, east, and west walls of the unit. The exposed portion of the hearth contains 51 rocks ranging from 3-18 $\mathrm{cm}$ in size (Figure 14). All but 10 of these rocks are angularly fractured and show evidence of cooling in place. A circular pattern can be seen in the placement of the rocks along the north side of the feature. The feature consists of one and two layers of rock; no pit outline was visible in profile. The matrix from the feature level was collected for flotation. A small amount of charcoal recovered from beneath one feature rock (Beta-82227) returned a date of 8955 (8655) 8545 B.P. (two sigma). Seven archaeomagnetic samples were taken from this feature. The results indicate these rocks cooled in place and that this feature is intact (seeWulf Gose, Appendix C).

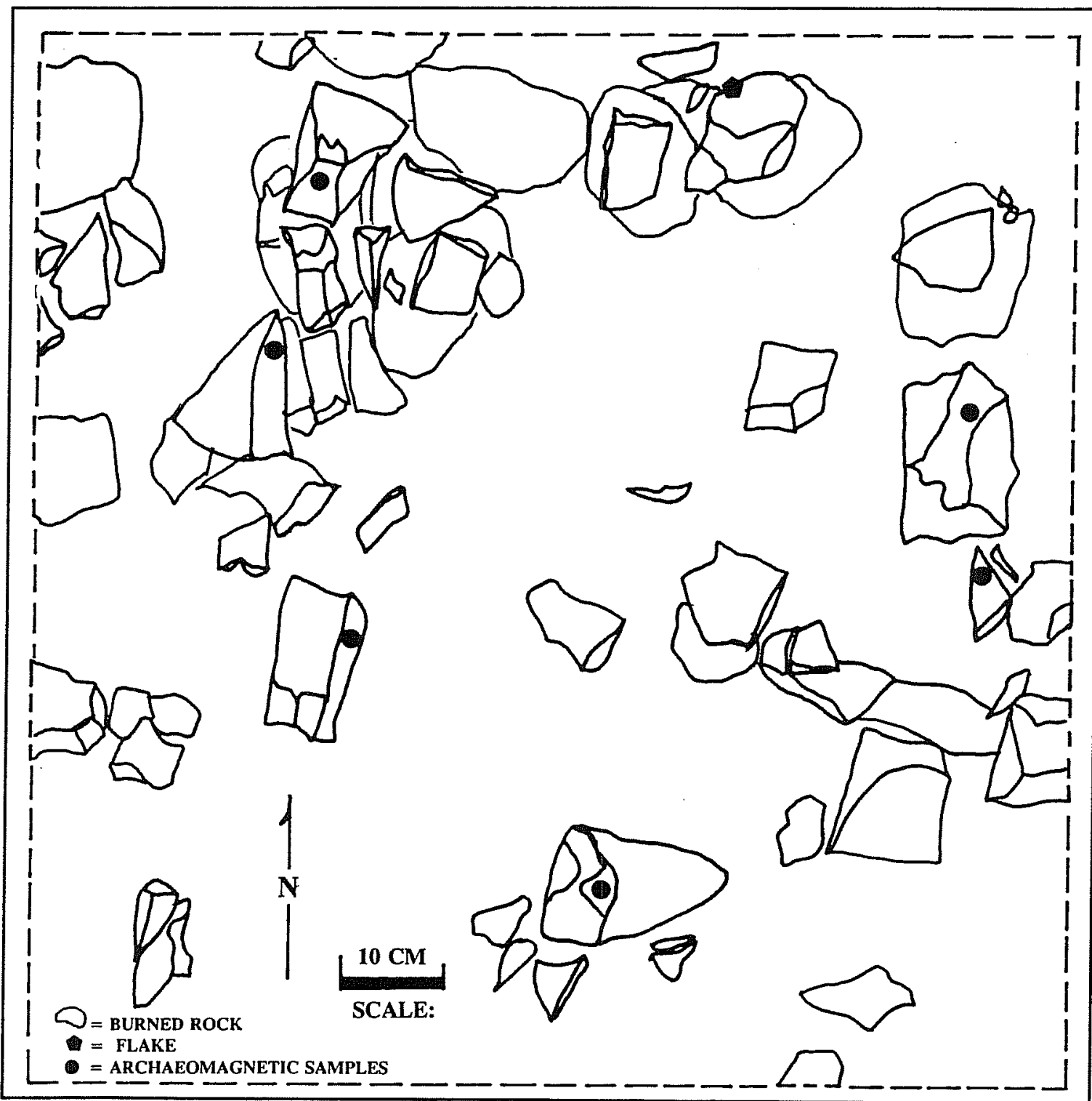

Figure 14. Feature 49. 


\section{BURNED-ROCK SCATTER FEATURES}

Twenty-two features uncovered in 14 Gradall trenches have been classified as burned rock scatters. These features are generally elongated, amorphous. They are found at depths from $24-100 \mathrm{~cm}$ bs in clusters that vary from large scatters with over 100 rocks to small groups of 3-6 rocks.
Feature 31 is one of two features exposed in trench $L 6 / G 7$ on the west side of the site. It is composed of nine angularly fractured burned rocks and one unburned rock (Figure 15). The scatter appears to consist of a single layer of rock in an elongated cluster measuring $40 \times 50$ $\mathrm{cm}$. One tertiary flake was recovered in situ from this feature.

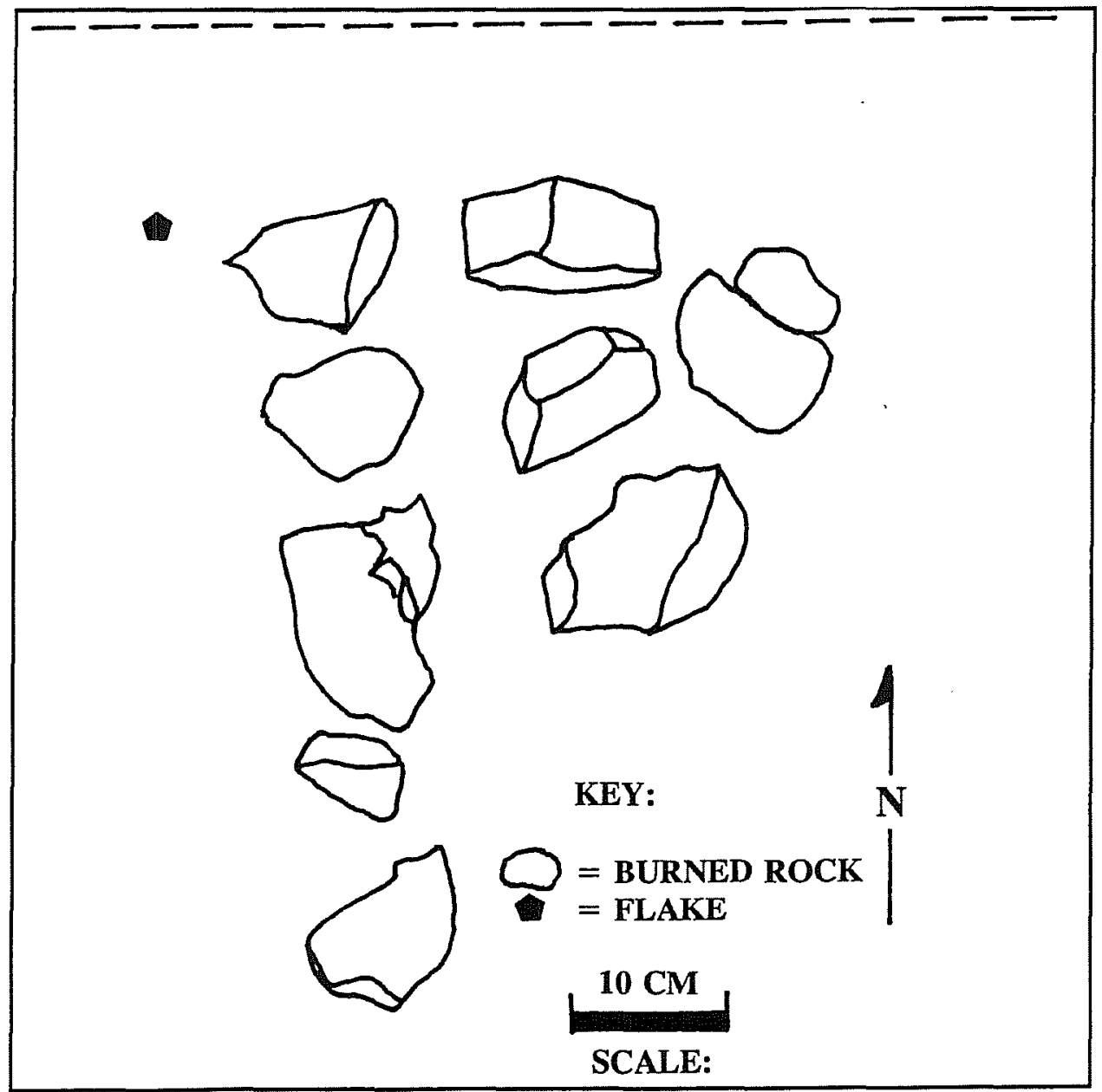

Figure 15. Feature 31. 


\section{ARTIFACT DESCRIPTIONS}

Artifacts recovered during the Phase II testing at 41BX47 include animal teeth, chipped stone, and charcoal (Appendix B).

\section{TEETH}

Portions of one animal tooth and one rodent jaw were recovered. The tooth fragment from $100-110 \mathrm{~cm}$ bs in test unit GT1/U1 is badly eroded and retains little or no enamel. The condition of this tooth prohibits positive identification but the size and shape indicated a large bovine.

A rodent jaw was recovered during recording of Feature 57. It belongs to Sigmodon hispida, the hispid cotton rat, indigenous to this area and common today. This tooth may not have cultural origins, as no other cultural material was recovered from this feature.

\section{CHIPPED STONE}

In total, 4,271 lithic artifacts were collected from Gradall trenches $(n=287)$ and test units $(n=3,984)$ during the current phase of work at $41 B X 47$ (Table 4). Vertical distribution of the artifacts from tests units is shown in Table 5

Following analytical categories used by Potter and Black (1995) the lithics were first divided into two broad groups: lithic manufacturing debris or debitage, and the finished products, i.e., formal tools (Table 4). Analytical categories within the groups are defined as follows.

Primary flake: 100 percent cortex on dorsal face; striking platform and bulb of percussion present.

Secondary flake: 1-99 percent cortex on dorsal face; striking platform and bulb of percussion present.

Tertiary flake: 0 percent cortex on dorsal face; striking platform and bulb of percussion present.

Table 4. Lithic Artifacts for the Entire Site

\begin{tabular}{|l|c|c|l|c|c||}
\hline \multicolumn{3}{|c|}{ Debitage } & \multicolumn{3}{c|}{ Formal Tools } \\
\hline \multicolumn{1}{|c|}{ Type } & $\mathbf{n}$ & $\boldsymbol{\%}$ & \multicolumn{1}{c|}{ Type } & $\mathbf{n}$ & $\%$ \\
\hline Primary & 3 & $<.01$ & Retouched Flake & 73 & 1.7 \\
\hline Secondary & 290 & 6.8 & Uniface & 4 & $<.01$ \\
\hline Tertiary & 1701 & 39.9 & Biface & 43 & 1.0 \\
\hline Cores & 7 & .2 & Point & 24 & .6 \\
\hline Chips & 2126 & 49.8 & Total & $\mathbf{1 4 4}$ & $\mathbf{3 . 3 \%}$ \\
\hline Total & $\mathbf{4 1 2 7}$ & $\mathbf{9 6 . 7 \%}$ & & & \\
\hline
\end{tabular}


Table 5. Vertical Distribution of Test Unit Artifacts

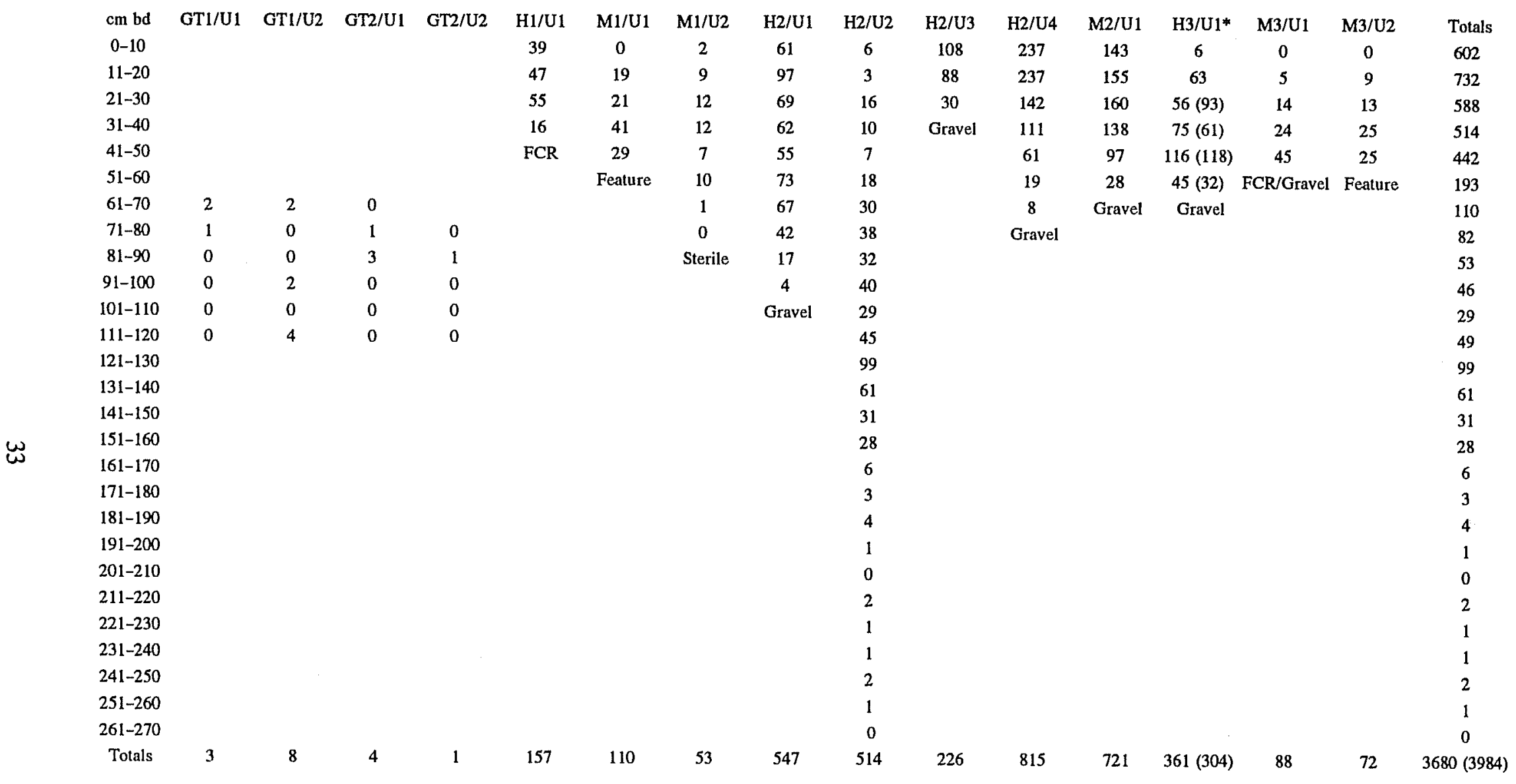

* numbers in parentheses indicate additional flakes recovered from $1 / 8$-inch screen 
Retouched flake: flake with platform and bulbs of percussion remaining; showing evidence of additional flake removal from some edges.

Uniface: altered by flake removal from one face only.

Biface: altered by flake removal from both sides to shape object.

Cores: parent material from which flakes have been detached. Cores exhibit numerous scars from flake removal.

Point and Point Fragment: complete or partial projectile point.

Chips and chunks: debitage not exhibiting striking platforms or bulbs of percussion, but exhibiting conchoidal fractures.

The lithic analysis suggests that little primary reduction occurred on the site. Instead, the frequencies of secondary debitage ( 7 percent of total debitage) and especially tertiary debitage (41.2 percent of total debitage) suggest that the final stages of tool manufacturing and perhaps resharpening of chipped stone tools were the most common knapping activities at the site.

The frequencies of formal tools indicate that retouched flakes ( 50.7 percent of tools) were the most commonly discarded tool form, and that bifaces were also very common ( 46.5 percent of tools).

\section{Formal Tools}

\section{Projectile Points}

The projectile points described here were recovered during monitoring and excavation. These 23 identifiable projectile points and point fragments represent a prehistoric time span of as much as 8,000 years (Table 6).
Temporal reclassification of many of the southcentral Texas projectile points has recently been proposed (Johnson and Goode 1994; Potter and Black 1995). However, as this repositioning is still in the formative stage and has yet to be accepted by the archaeological community, Prewitt's $(1981,1985)$ point type chronology is used here. Each point has been given a Unique Item (UI) number; these identifiers are used throughout this report. Projectile point classification follows those of Turner and Hester (1993) and Davis (1991).

Late Paleoindian. UI 31 (Figure 16a) is a complete lanceolate-shaped Angostura point with a contracting base and ground basal edges. Failed attempts at characteristic parallel thinning flakes end in visible hinge fractures on both the dorsal and ventral surfaces. One side of this point is heavily patinated, the other bears calcium carbonate deposits. UI 31 was recovered from $51 \mathrm{~cm}$ bs in the gravel deposit at the bottom of trench $H 1 M 1 / G 1$. Given this association with alluvial gravels, we are unsure that this point was found in situ.

UI 39 (Figure 16b) is a portion of an Angostura with a concave base and classic ground basal edges and parallel flaking. The color of the parent material is obscured by heavy patination on all sides. This point was found in situ with two hearth features, $125 \mathrm{~cm}$ below datum (bd) in test unit $\mathrm{H} 2 / \mathrm{U} 2$.

UI 43 (Figure 16c) is a reworked basal portion of an Angostura. This point retains its concave base, ground edges, and oblique parallel flake scars, but the distal end has been crudely reshaped. UI 43 was found in the Gradall dirt pile from trench F/G16 from an approximate depth of $44-45 \mathrm{~cm}$ below the surface.

Early Archaic. Four of the points in this collection have the expanding, split stems; corner notching; and barbs that typify point types from the Early Archaic (Potter and Black 1995). The broken tips of each of these points bear impact fractures. 
Table 6. Projectile Points

\begin{tabular}{|c|c|c|c|c|c|c|c|c|}
\hline UI \# & $\underset{\#}{\text { Figure }}$ & Location & Depth cm & $\begin{array}{c}\text { Length } \\
\text { (mm) }\end{array}$ & $\begin{array}{c}\text { Width } \\
\text { (mm) }\end{array}$ & $\begin{array}{c}\text { Thickness } \\
\text { (mm) }\end{array}$ & Type & Period \\
\hline 20 & $17 \mathrm{~h}$ & M1L3/G1 & $* 50$ & 59.5 & 28 & 6 & Pedernales & M. A. \\
\hline 21 & $17 \mathrm{a}$ & $\mathrm{M} 2 / \mathrm{G} 2$ & $+24-28$ & - & 29 & 5.5 & Nolan-like & M. A. \\
\hline 22 & $17 f$ & $\mathrm{M} 2 / \mathrm{G} 2$ & $24-28$ & - & - & - & Pedernales & M. A. \\
\hline 23 & $17 \mathrm{~b}$ & M2/G2 & $+24-28$ & - & - & - & Bulverde & M. A. \\
\hline 24 & $17 \mathrm{c}$ & M1L3/G1 & $* 32$ & 56 & 35.5 & 7 & Bulverde & M. A. \\
\hline 25 & $18 \mathrm{c}$ & $\mathrm{H} 2 / \mathrm{G}_{2}(\mathrm{FL} 23)$ & *10-20 & 54 & 24 & 7 & Kinney & M. A. \\
\hline 26 & $18 \mathrm{~g}$ & $\mathrm{H} 2 / \mathrm{G} 2(\mathrm{Ft} 23)$ & *10-20 & - & - & - & Marcos & L. A. \\
\hline 27 & $17 \mathrm{~g}$ & M1L3/G1 & Surface & - & 35 & 8.5 & Pedernales & M. A. \\
\hline 28 & $17 \mathrm{e}$ & $\mathrm{H} 2 / \mathrm{G} 2$ (Ft23) & *10 & - & - & 6.5 & Pedernales & M. A. \\
\hline 29 & $18 d$ & $\mathrm{M} 2 / \mathrm{G} 2$ & $* 12-16$ & - & 27 & 6.5 & Kinney & M. A. \\
\hline 30 & $16 \mathrm{~g}$ & $\mathrm{H} 2 / \mathrm{U} 1$ & 32 & - & 20.5 & 7 & Hoxie-like & E. A. \\
\hline 31 & $16 a$ & H1M1/G1 & $* 51$ & 77.5 & 21 & 10.5 & Angostura & L.PI. \\
\hline 32 & $17 \mathrm{i}$ & M3/G1 & *9 & - & 38 & 6 & Pedernales & M.A. \\
\hline 33 & $17 \mathrm{~d}$ & $\mathrm{H} 2 / \mathrm{G} 3$ (Ft.25) & $* 20$ & 65 & 35 & 8 & Pedernales & M.A. \\
\hline 34 & $18 \mathrm{~h}$ & H1M1/G1 & Surface & - & - & 4 & Marcos & L.A. \\
\hline 35 & $18 \mathrm{~b}$ & $\mathrm{H} 2 / \mathrm{U} 1$ & 9.5 & - & 34 & 5.5 & Kinney & M.A. \\
\hline 36 & $16 \mathrm{~d}$ & $\mathrm{H} 2 / \mathrm{U} 2$ & 110 & - & 25.5 & 5.5 & Gower & E.A. \\
\hline 37 & $16 \mathrm{e}$ & $\mathrm{H} 2 / \mathrm{G} 3$ & $* 30-35$ & - & - & 6 & ECorNotch & E.A. \\
\hline 39 & $16 \mathrm{~b}$ & $\mathrm{H} 2 / \mathrm{U} 2$ & 125 & - & - & 5.5 & Angostura & L.PI. \\
\hline 40 & $18 \mathrm{f}$ & $\mathrm{H} 2 / \mathrm{U} 4$ & $10-20$ & 49 & - & 6 & Marcos & L.A. \\
\hline 41 & $18 \mathrm{a}$ & $\mathrm{M} 2 / \mathrm{U} 1$ & $0-10$ & - & - & 4 & Marshall & M.A. \\
\hline 42 & $16 f$ & F/G15 (Ft67) & $* 46$ & - & - & 6 & ECorNotch & E.A. \\
\hline 43 & $16 \mathrm{c}$ & F/G16 (Ft73) & $* 44-45$ & - & 11.5 & 5 & Angostura & L.PI. \\
\hline 45 & $18 \mathrm{e}$ & FG21 (Ft79) & $* 56$ & 59 & 18.5 & 6.5 & Pandora-like & M.A. \\
\hline
\end{tabular}

* indicates approximate depth of artifacts recovered from Gradall dirt

UI 36 (Figure 16d) is a heavily patinated Gower with short, side-notched barbs, a parallel-edged stem, and a concave base. The basal concavity has been formed by the removal of flakes from only one side. UI 36 was recovered in situ from $110 \mathrm{~cm}$ bd in test unit $\mathrm{H} 2 / \mathrm{U} 2,15 \mathrm{~cm}$ above the feature associated with UI 39, an Angostura point.

UI 37 (Figure 16e) is an unnamed cornernotched point with an expanding stem and a concave base. Flakes have been removed from both sides of the base to make the concavity.
This brown chert point is only lightly patinated. It was recovered from the dirt pile of Gradall trench $\mathrm{H} 2 / \mathrm{G} 3$ from an approximate depth of 30-35 cm bs.

UI 42 (Figure 16f) is another unnamed cornernotched point with a widely expanding stem and shallow concave base. The base has been thinly tapered by removal of multiple flakes from both sides. This heavily patinated point was recovered in the dirt pile of Gradall trench F/G15 from an approximate depth of $46 \mathrm{~cm}$ bs in possible association with hearth feature 67 . 


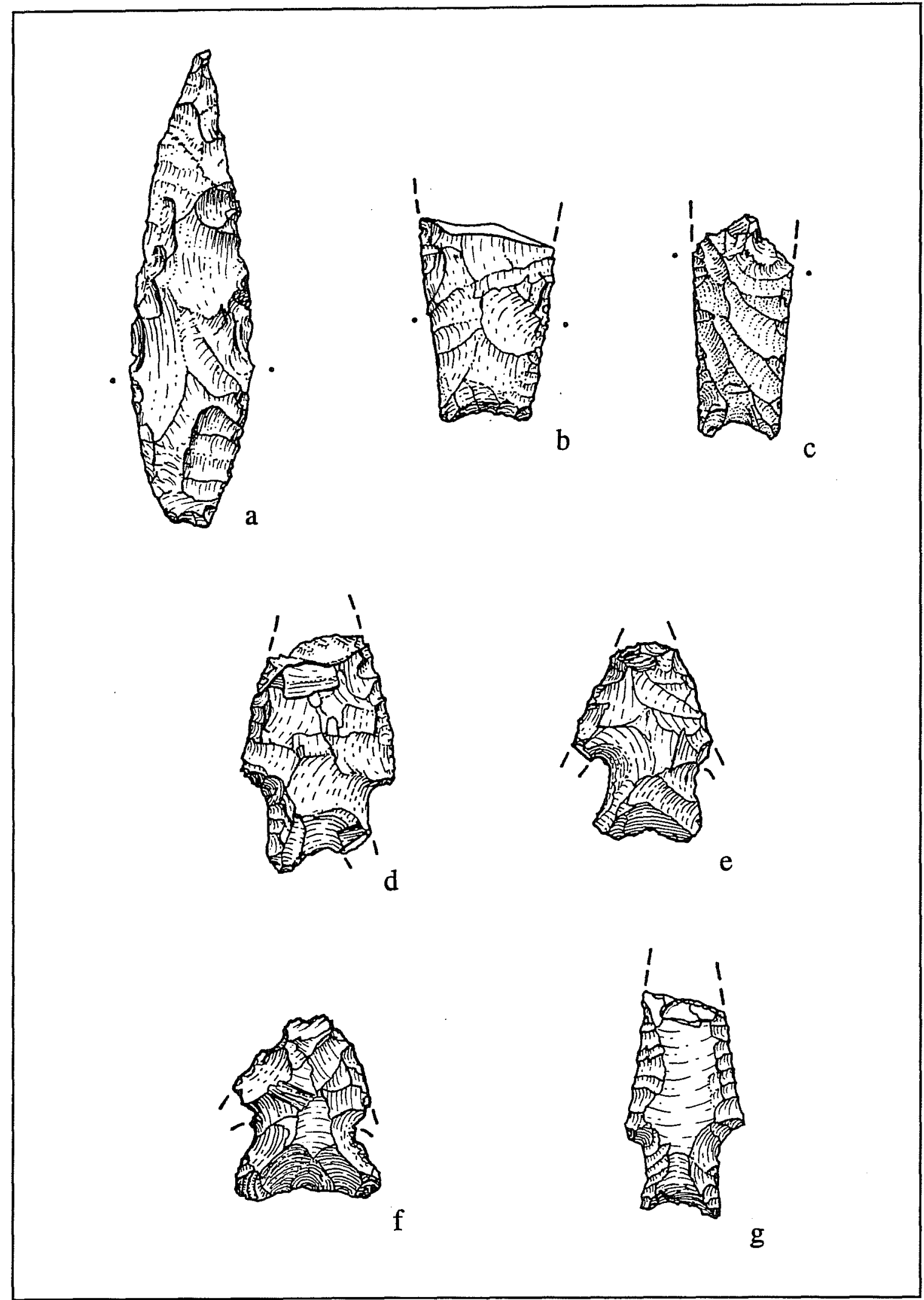

Figure 16. Late Paleoindian and Early Archaic points. a-c: Angostura; d: Gower; e, f: Early Corner-notched; g: Hoxie-like. All shown actual size. 
UI 30 (Figure 16g) has the almost parallel stem, concave base and small, side/corner-notched barbs characteristic of the Hoxie type. The stem, however, lacks the classic smoothing or grinding typical of Hoxie points. This point was found in situ, $32 \mathrm{~cm}$ bd, in test unit $\mathrm{H} 2 / \mathrm{U} 1$.

Middle Archaic. Fourteen of the diagnostic points from this collection date to the Middle Archaic. All but one of the points described below (UI 32) were found in or near the midden deposits in the north or west sections of the site.

UI 21 (Figure 17a) is a partial point that has been classified as Nolan-like based on slight alternate beveling and a thinly tapered base. The stem is, however, uncharacteristically narrow, making the shoulders pronounced. Heavy patination is present on one side of this point found in the Gradall dirt from trench M2/G2 at approximately $24-28 \mathrm{~cm}$ bs.

UI 23 (Figure 17b) is a partial Bulverde point retaining only the base and one shoulder. The stem is straight, the base tapered, and the remaining shoulder strong. This point fragment was collected from the Gradall dirt pile of trench $\mathrm{M} 2 / \mathrm{G} 2$ from approximately $24-28 \mathrm{~cm}$ bs.

UI 24 (Figure 17c) is a complete Bulverde recovered from the Gradall dirt pile of L3M1/G1 at an approximate depth of $32 \mathrm{~cm}$ bs. It has moderate barbs, a straight stem, and thin, tapering base. UI 24 is lightly patinated on one side and heavily patinated on the other.

UI 33 (Figure 17d) is a complete Pedernales point recovered from the Gradall back dirt removed from approximately $20 \mathrm{~cm}$ bs in trench H2/G3. This lightly patinated, broad, leafshaped point has the classic rectangular, bifurcated stem. A broad, flute-like thinning flake is visible on one side of the base.

UI 28 (Figure 17e) is an almost complete Pedernales point collected from a Gradall dirt pile in trench $\mathrm{H} 2 / \mathrm{G} 2,10 \mathrm{~cm}$ bs. Its bifurcated, rectangular stem displays a broad thinning flake on one side. An impact fracture is present on the broken distal end.

UI 22 (Figure 17f) is a basal fragment retaining enough of the stem and thinning flake to allow the identification as Pedernales. It was found in Gradall back dirt from trench M2/G2 from approximately $24-28 \mathrm{~cm}$ bs in the same level as UI 23, a Bulverde point.

UI 27 (Figure 17g) is the heavily patinated medial section and half the bifurcated base of a Pedernales point. It was found on the surface at the edge of Gradall trench L3M1/G1.

UI 20 (Figure 17h) is a complete Pedernales point recovered from the upper $50 \mathrm{~cm}$ of Gradall trench dirt from L3M1/G1. This point has basal thinning flakes on both sides.

UI 32 (Figure 17i) is a nearly complete Pedernales point, missing only the distal tip. It was collected from $9 \mathrm{~cm}$ bs in the dirt pile of Gradall trench M3/G1. The broken distal end of this point show evidence of an impact fracture.

UI 41 (Figure 18a) is a Marshall point recovered from the $0-10 \mathrm{~cm}$ level of test unit $\mathrm{M} 2 / \mathrm{U} 1$ in the northern portion of the site. It has a slightly expanding stem and a flat base. Both barbs are missing.

UI 35 (Figure 18b) was recovered in situ from $9.5 \mathrm{~cm}$ bd in test unit $\mathrm{H} 2 / \mathrm{U} 1$ in the northern portion of the site. It is an unstemmed, triangular Kinney point with a deeply concave base.

UI 25 (Figure 18c) is an elongated Kinney with a slightly concave base. It was collected from an approximate depth of $10-20 \mathrm{~cm}$ bs in a Gradall dirt pile from trench $\mathrm{H} 2 / \mathrm{G} 2$, within the northern midden deposit.

UI 29 (Figure 18d) is another elongated Kinney point from the northern section of the site. It was found in a Gradall dirt pile from trench M2/G2 from an approximate depth of $12-16 \mathrm{~cm}$ bs. 


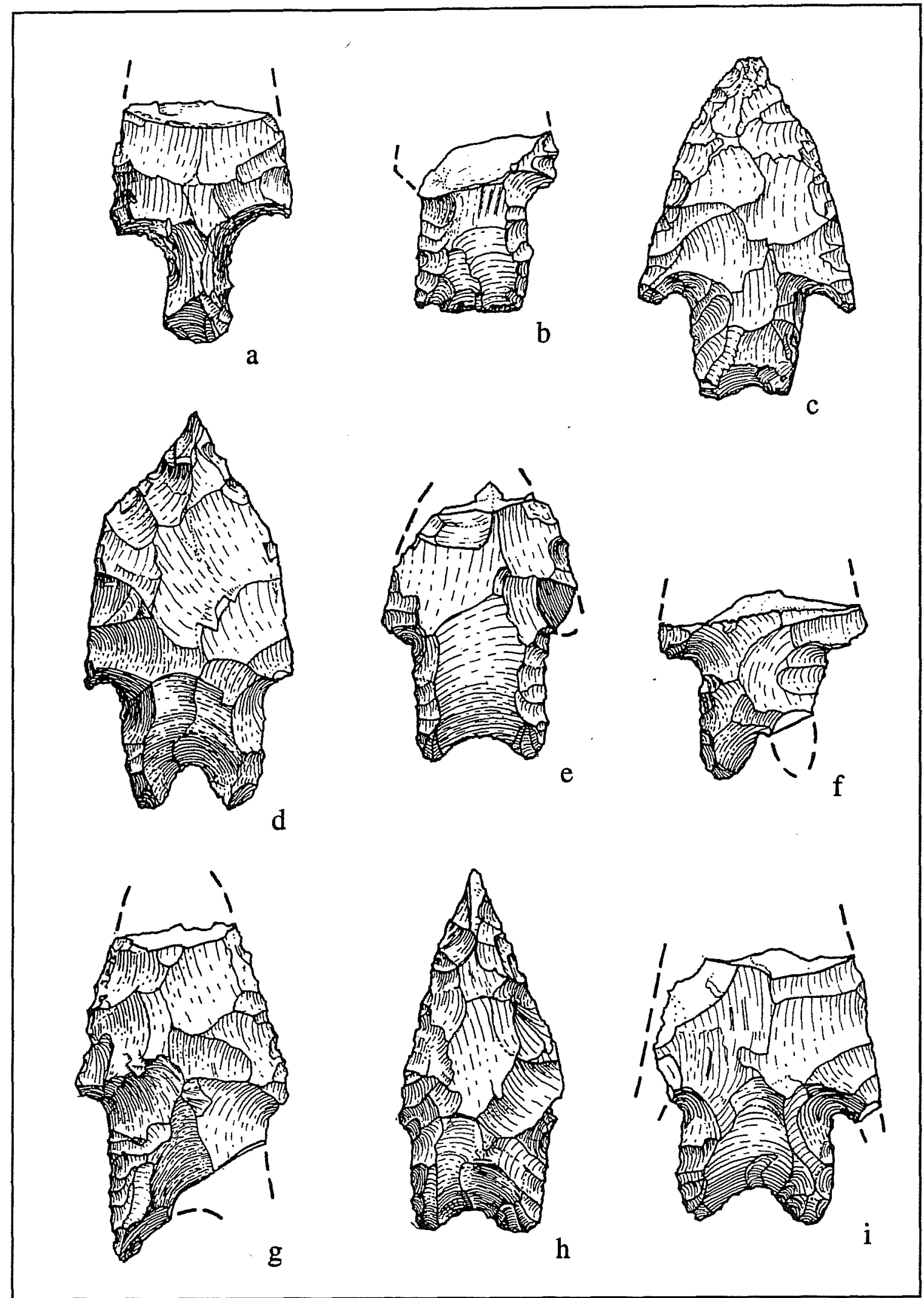

Figure 17. Middle Archaic points. a: Nolan-like; b, c: Bulverde; d-i: Pedernales. All shown actual size. 


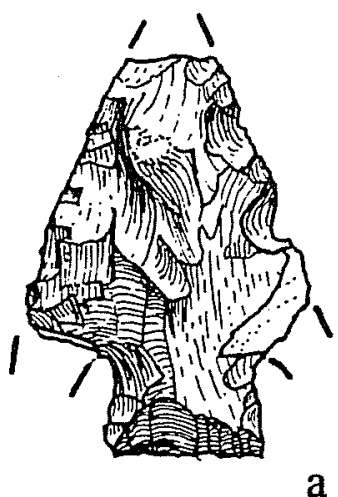

a
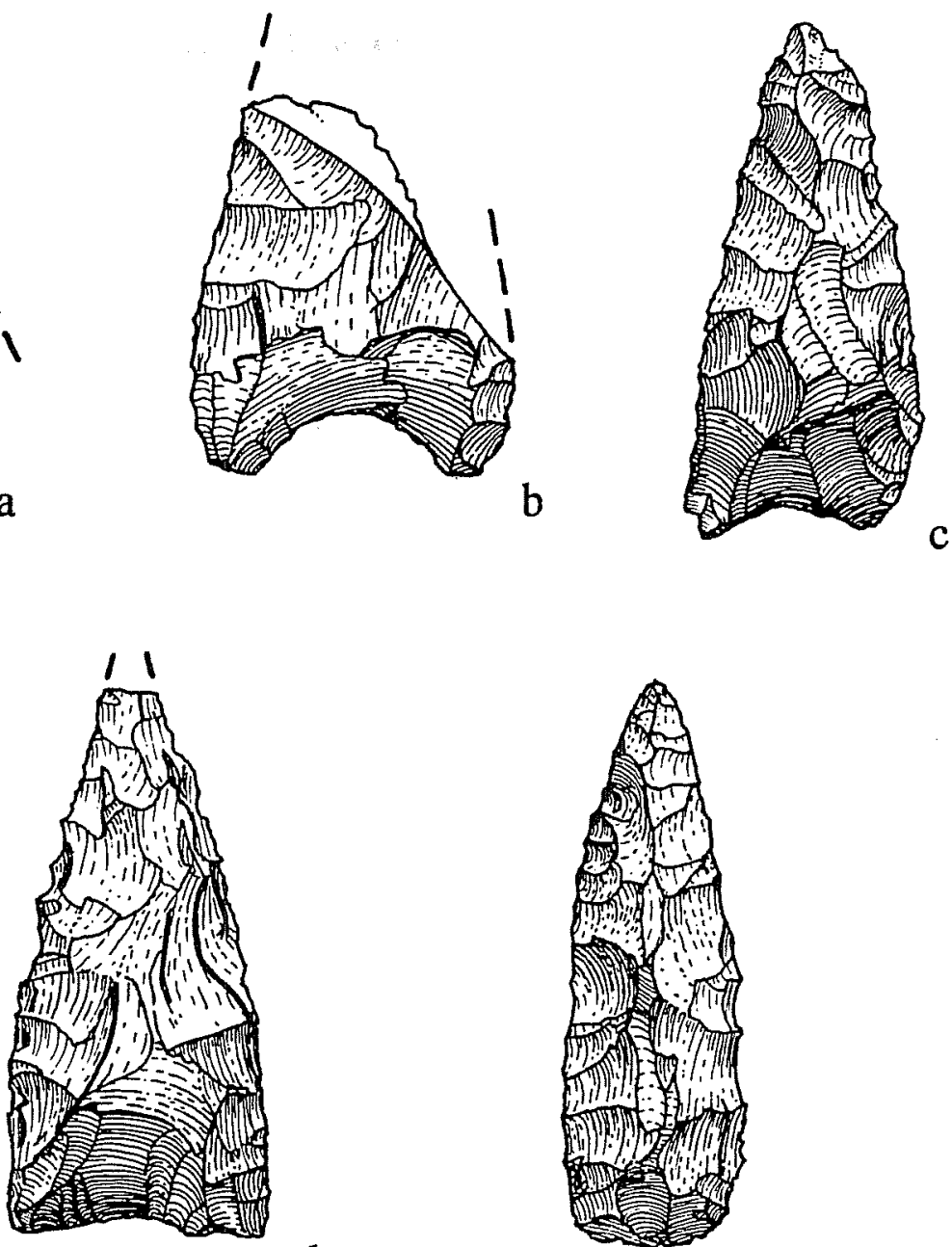

d
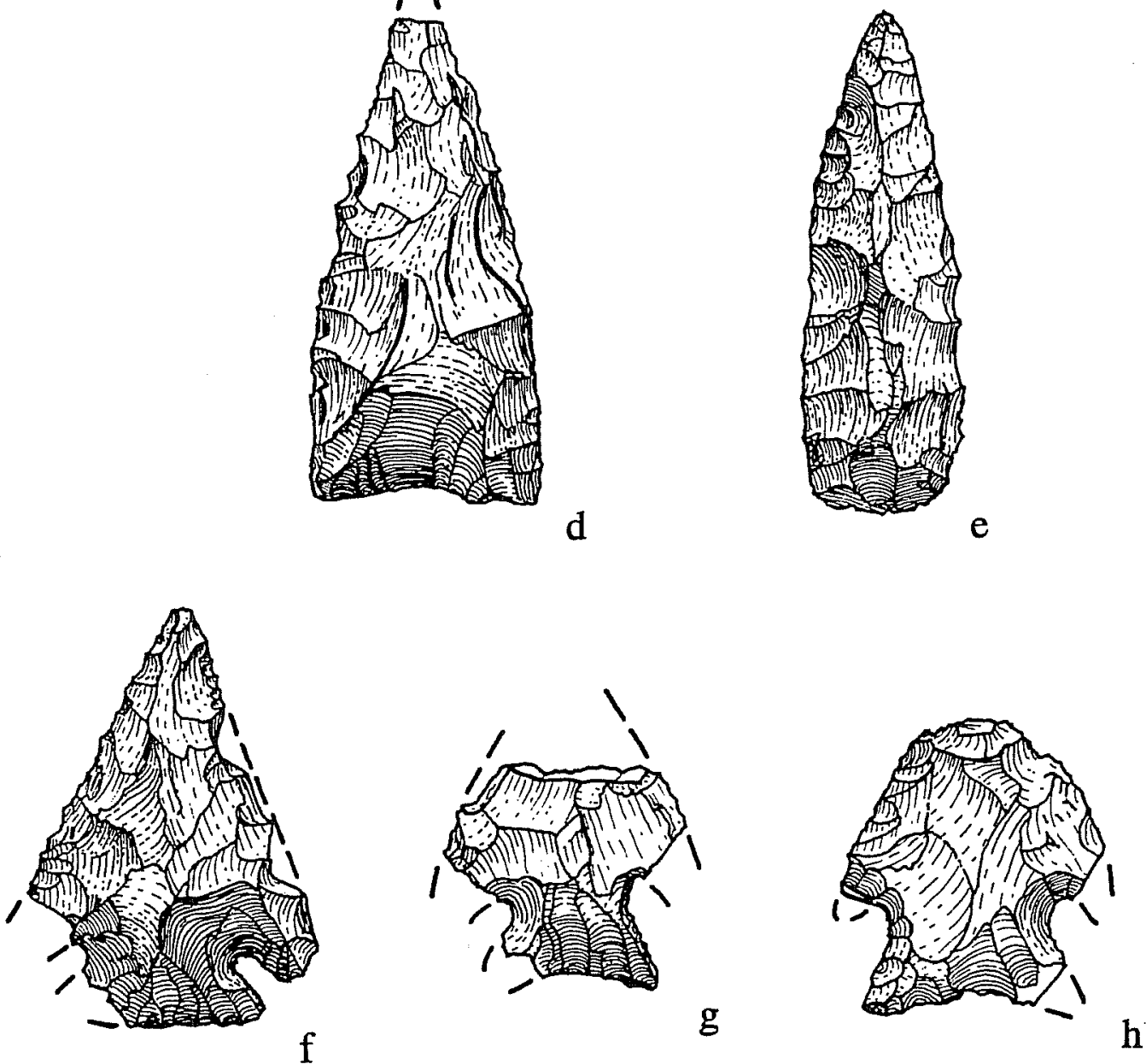

Figure 18. Middle and Late Archaic points. a: Marshall; b-d: Kinney; e: Pandora; f-h: Marcos. All shown actual size. 
UI 45 (Figure 18e) is an elongated, unstemmed point with a straight, tapering base, classified as a Pandora. It was recovered from an unknown depth in a dirt pile from Gradall trench F/G21 in the western portion of the site. The discoloration and one large heat-spall on the base of UI 45 indicate heating.

Late Archaic. The Late Archaic is represented by three Marcos points found in direct association with the west and north midden deposits.

UI 40 (Figure 18f) is an almost complete point with the sharply expanding stem and corner notches characteristic of the Marcos point. It was found $10-20 \mathrm{~cm}$ bd in test unit H2/U4 at the edge of the northern midden deposit.

UI 26 (Figure 18g) is a basal section with a sharply expanding stem that identifies it as a Marcos. This fragment was found in a Gradall trench dirt pile from an approximate depth of $10-20 \mathrm{~cm}$ bs in trench $\mathrm{H} 2 / \mathrm{G} 2$ within the northern midden deposit.

UI 34 (Figure 18h) is a nearly complete Marcos point collected from the surface at trench M1H1/G1, the trench containing the western midden deposit. It has a slightly concave base and expanding stem created by corner notching.

\section{CHARCOAL SAMPLES}

Six charcoal samples were collected during this phase of testing (Table 7). Sample 4, from test unit M1/U2, was collected during excavation of Feature 48 in that unit. Feature 48 is a small, circular hearth located $45-55 \mathrm{~cm}$ bs in the western section of the site in the T3 terrace. This sample was selected for dating to supply chronological information for the upper $50 \mathrm{~cm}$ of the T3 terrace and the midden and hearth features found there (Table 8).

A very small charcoal sample (Sample 6) was collected from $175 \mathrm{~cm}$ bs in test unit $\mathrm{H} 2 / \mathrm{U} 2$ during excavation of Feature 49 . Feature 49 was the deepest feature discovered at $41 \mathrm{BX} 47$ and was $45 \mathrm{~cm}$ below Feature 30, the feature associated with the Angostura point. This sample was selected for accelerator dating (Table 8).

The date between $5235(4965,4935,4885) 4850$ B.P. for the charcoal from Feature 48 (sample 4) places this feature and the surrounding cultural deposits in the Middle Archaic period (Table 8). This corresponds with the Middle Archaic Bulverde and Pedernales points recovered from the top $50 \mathrm{~cm}$ of trench M1L3/G1 five meters to the south and is within the age estimate for geomorphological Unit III (see page 20). This date supports the classification of the western fire-cracked rock deposit in nearby trench H1M1/G1 (Feature 9) as a Middle Archaic burned rock midden.

Table 7. Charcoal Samples

\begin{tabular}{|c|c|l|l||}
\hline Sample & Location & \multicolumn{1}{|c|}{ Depth } & \multicolumn{1}{c|}{ Comments } \\
\hline 1 & M1/U1 & $50-60 \mathrm{~cm} \mathrm{bd}$ & outside Ftr. 48 \\
\hline 2 & F/G9 & $53 \mathrm{~cm} \mathrm{bs}$ & recent root disturbance \\
\hline 3 & $\mathrm{M} 2 / \mathrm{U} 1$ & $60 \mathrm{~cm} \mathrm{bd}$ & in gravels \\
\hline 4 & $\mathrm{M} 1 / \mathrm{U} 2$ & $45-56 \mathrm{~cm}$ bd & inside Ftr. 48 (submitted for dating) \\
\hline 5 & $\mathrm{H} 2 / \mathrm{U} 2$ & $150-160 \mathrm{~cm} \mathrm{bd}$ & possible rodent disturbance \\
\hline 6 & $\mathrm{H} 2 / \mathrm{U} 2$ & $175 \mathrm{~cm}$ bd & inside Ftr. 49 (submitted for dating) \\
\hline
\end{tabular}


Table 8. Radiocarbon Results

\begin{tabular}{||c|c|c|c|c|c|c||}
\hline Sample \# & Ftr. \# & Beta \# & Uncorrected & 1 Sigma & \multicolumn{1}{|c|}{ 2 Sigmas } & Intercept \\
\hline $\begin{array}{c}4 \\
\text { charcoal }\end{array}$ & 48 & 82228 & $4390 \pm 50$ B.P. & 5020 to 4865 B.P. & $\begin{array}{l}5235 \text { to } 5195 \\
\text { and } \\
5055 \text { to } 4850 \\
\text { B.P. }\end{array}$ & $\begin{array}{l}4965,4935, \\
\text { and } \\
4885 \text { B.P. }\end{array}$ \\
\hline $\begin{array}{c}6 \\
\text { charcoal }\end{array}$ & 49 & $\begin{array}{c}82227 \\
\text { (AMS) }\end{array}$ & $7920 \pm 50$ B.P. & $\begin{array}{l}8925 \text { to } 8870 \text { and } \\
8840 \text { to } 8795 \text { and } \\
8730 \text { to } 8580 \text { B.P. }\end{array}$ & $\begin{array}{l}8955 \text { to } 8545 \\
\text { B.P. }\end{array}$ & 8655 B.P. \\
\hline humate & & 81546 & $5810 \pm 50$ B.P. & & & \\
\hline humate & & 81547 & $7440 \pm 100$ B.P. & & & \\
\hline
\end{tabular}

The charcoal date of 8955 (8655) 8545 B.P. (sample 6) from Feature 49 in unit H2/U2 demonstrates the stratigraphic integrity of this deep deposit in the north section of the site. This Early Archaic feature is located $170 \mathrm{~cm}$ bs and is overlain with a Angostura point at $125 \mathrm{~cm}$ and a Gower point at $110 \mathrm{~cm}$. 


\section{CHAPTER 5: ANALYSIS}

\section{FEATURE ATTRIBUTE ANALYSES}

Attributes recorded for each feature include depth below surface, number of rocks, and dimensions. In the following analyses, these attributes are compared by feature type to identify spatial, temporal, and functional patterns. Of the 84 feature identified, 31 -including the 2 oven and 3 midden features-were only partially exposed in Gradall trenches and test units, giving incomplete attribute information. Therefore, the following analysis reflects only those features for which we have complete information.

\section{FEATURE DEPTHS}

Depth below surface was recorded for the tops of all feature $(n=84)$. A histogram of these depths indicates the primary mode is between 50 and $60 \mathrm{~cm}$ bs (Figure 19). The feature depth distribution is controlled by the depths of the most numerous feature type, the hearth.
Mean depth recorded for the 57 hearth features was $56.33 \mathrm{~cm}$ below surface ( $\mathrm{std}=3.51$ ). Sixtysix percent of these were uncovered between 30 and $60 \mathrm{~cm}$ bs. A secondary mode occurs at the $70 \mathrm{~cm}$ level, followed by minor modes $110-120$ $\mathrm{cm}$ and $160 \mathrm{~cm}$. These varying feature depths correspond with the undulating chute fills and floodbasin deposits in the T3 and T4 terraces within the Early Holocene Unit II identified during the geomorphological study. Scatters are distributed similarly to hearths, but peak at 40 $\mathrm{cm}$ bs (mean depth $=54.22$, $\mathrm{std}=3.59$ ). The two oven features occur at 40 and $60 \mathrm{~cm}$ bs, the most frequent depths for both hearths and scatters.

The burned rock midden features occur near the surface in two areas of the site (mean depth= 21.67, std $=2.85, n=3$ ). The two features comprising the northern midden occur within Unit III on the T1 flood terrace. Feature 9, identified as the western midden, is within IV in T2 flood terrace. Both of these soil units were deposited during the late Holocene.

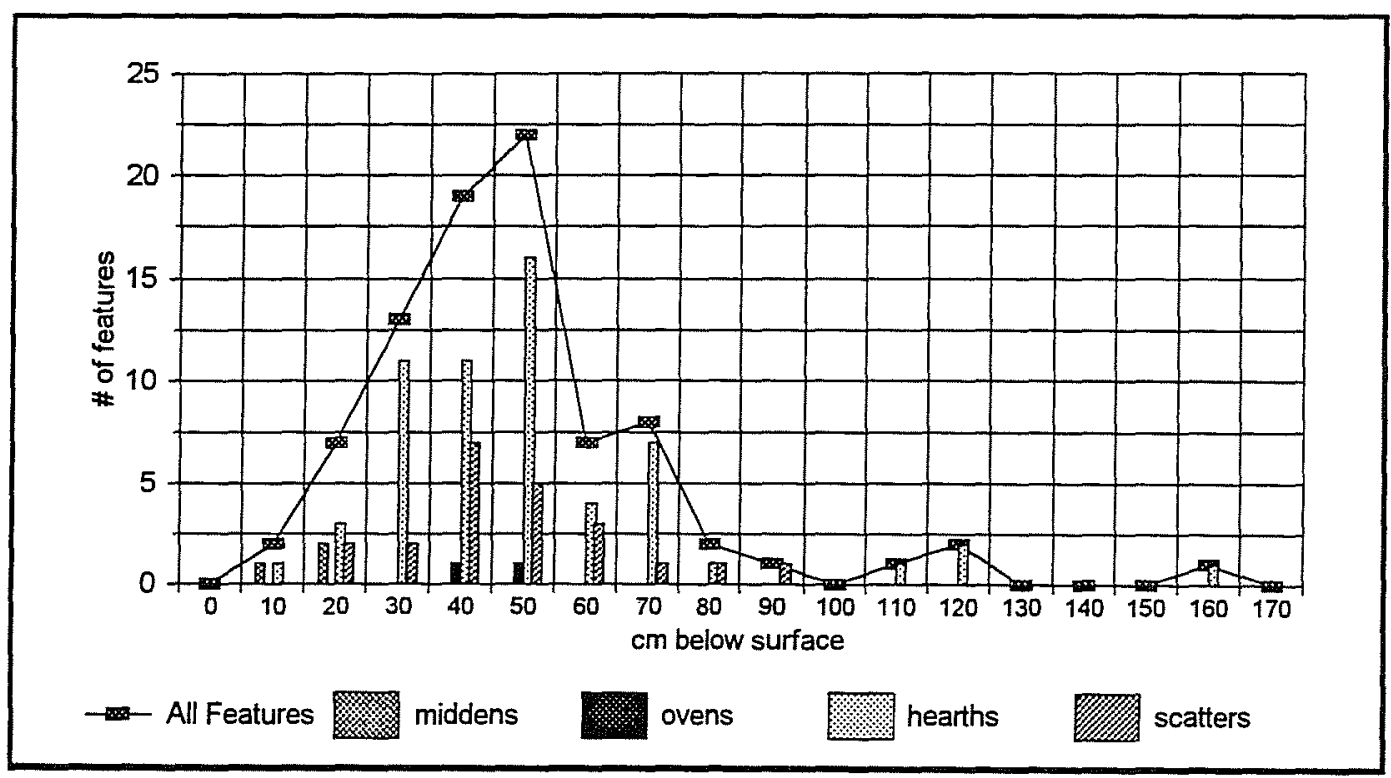

Figure 19. Depths by feature type. 
Because excavations in trenches and in all but one test unit were halted when features were encountered, the presence of additional deep features within unidentified chute fills can not be ruled out. However, through geomorphological evaluation and stratigraphic control obtained from completely excavated trenches and test units, the depth of non-cultural deposits was identified over much of the site.

\section{NUMBER OF ROCKS}

The frequency comparison of the number of rocks in each feature is based on those features that were totally exposed during excavation (total $n=54$, hearth $n=39$, scatter $n=15$ ). The three midden features and the two oven features were not completely exposed and are therefore not included in the following analyses. Exposed portions of the middens however consisted of more than 200 rocks and ovens contained in excess of 47 and 82 rocks respectively.

The number of rocks per hearth feature ranges from a minimum of 4 to a maximum of 51 with a mean of $19.9(\mathrm{std}=12.8)$. As seen in Figure
20 , the number of rocks occurring in hearth features follows a normal distribution, peaking between 11-15 rocks per hearth. While scatters display a weakly bimodal distribution with peaks at 10 and 30 rocks per scatter (mean $=15.7$, std $=11.8$ ) the overall distribution patterns are similar. A $\mathrm{T}$ test performed to measure this variability resulted in no significant difference at a .05 level of confidence $(t=-1.83, p=.074$ two-tailed, $\mathrm{df}=52$ ).

\section{FEATURE SIZE}

Feature size (Figure 21), based on area, was computed from north/south and east/west dimensions of totally exposed features $(n=54)$. This is an approximate size used here to compare features of different shapes. Midden and oven features were again excluded from this analysis due to lack of complete dimensional information, but partial exposure in Gradall trenches indicates the middens range in size from 1.6-9 $\mathrm{m}$ in length and more than $1.7 \mathrm{~m}$ wide. Oven areas are smaller, with dimensions ranging from $.96 \mathrm{~m}^{2}-2.89 \mathrm{~m}^{2}$.

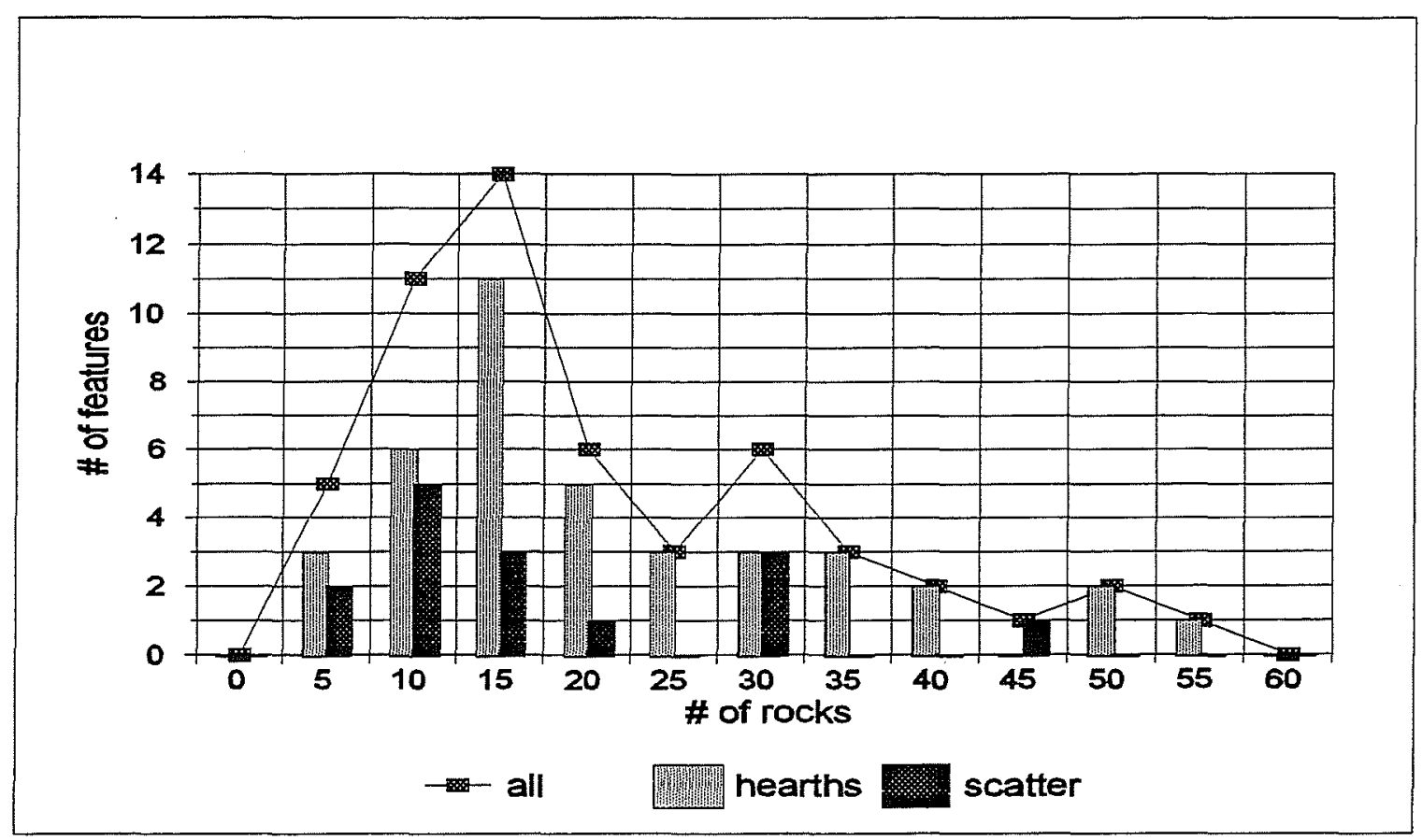

Figure 20. Number of rocks. 


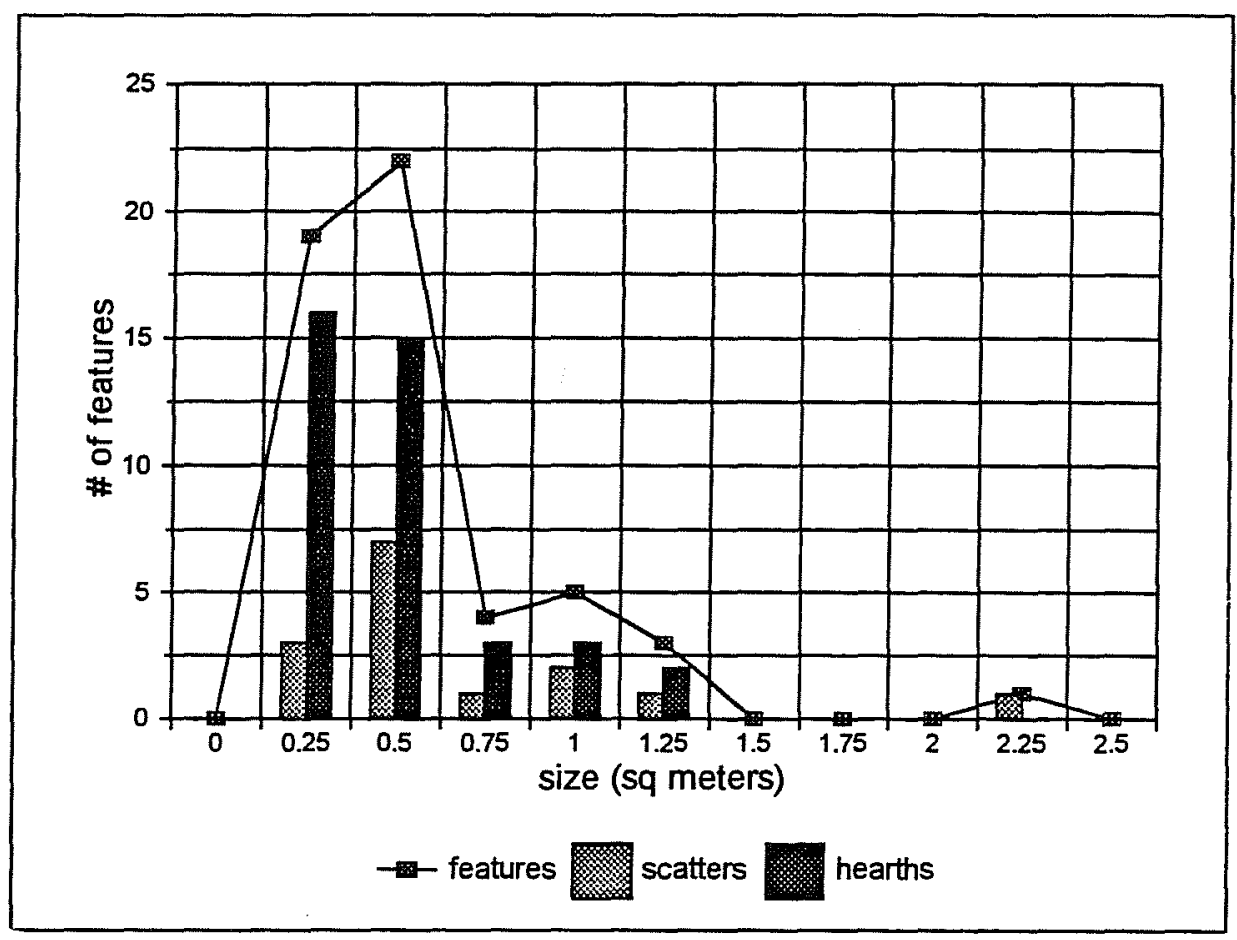

Figure 21. Hearth and scatter area.

Hearth areas range from .039 to $1.2 \mathrm{~m}^{2}$, with a mean area of $.38 \mathrm{~m}^{2}\left(\mathrm{std}=.295 \mathrm{~m}^{2}\right)$. Forty-one percent (16) of the hearths cluster from .25 to.5 $\mathrm{m}^{2}$ in area. Scatters are more irregularly patterned, ranging in area from .124 to $2.25 \mathrm{~m}^{2}$, with a mean dimension of $.59 \mathrm{~m}^{2}\left(\mathrm{std}=.52 \mathrm{~m}^{2}\right)$. A $\mathrm{T}$ test to compare hearth and scatter areas resulted in no significant difference at a .05 level of confidence $(\mathrm{t}=1.12, \mathrm{p}=.27$ two-tailed, $\mathrm{df}=52$ ).

\section{NUMBER OF ROCKS AND AREA}

A comparison of the relation between feature area and the number of rocks per feature reveals a positive correlation between these variables for both feature types. This finding supports the above rock-number and feature-size analyses suggesting that the distinctions between hearths and scatters made in the field could not be verified quantitatively. Scatters may actually be disturbed hearths. The higher degree of discoloration and fracturing noted in the rocks in scatter features may be the result of functional or depositional factors not evident at this level of investigation.

\section{HORIZONTAL AND VERTICAL RELATIONSHIP}

The features do not appear to be isolated, unrelated finds. Of the 31 Gradall trenches that contained features, 17 (55 percent) contained multiple features, ranging from 2-7 per trench. The horizontal and vertical feature locations plotted during Gradall excavations were used for the spatial analysis in Table 9. Average horizontal separations are based on measured distances between the centers of features occurring in the same trench. Horizontally, the 65 features revealed in the 17 multi-feature $25-x$ $1.7 \mathrm{~m}$ trenches were from 1-16 $\mathrm{m}$ apart with an average distance of $4.88 \mathrm{~m}$ between them. Vertically, features in the same trench were from $0-58 \mathrm{~cm}$ apart with an average vertical separation of $18.6 \mathrm{~cm}$. 
Table 9. Spatial Relationship of Features

\begin{tabular}{|c|c|c|c|c|c|c|c|c|c|c|}
\hline \multirow[b]{2}{*}{ Trench } & \multicolumn{2}{|c|}{ Hearths } & \multicolumn{2}{|c|}{ Scatters } & \multicolumn{2}{|c|}{ Middens } & \multicolumn{2}{|c|}{ Ovens } & \multirow[b]{2}{*}{$\begin{array}{c}\text { Avg. } \\
\text { Horz. } \\
\text { Separation }\end{array}$} & \multirow[b]{2}{*}{$\begin{array}{c}\text { Avg. } \\
\text { Vert. } \\
\text { Separation }\end{array}$} \\
\hline & F & 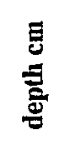 & 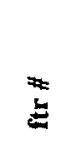 & 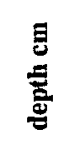 & $\begin{array}{l}\text { \#E } \\
\text { E }\end{array}$ & 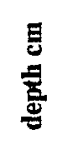 & 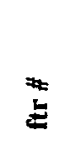 & 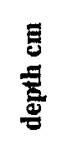 & & \\
\hline \multirow[t]{2}{*}{ F/G1 } & 37 & 54 & & & & & & & & \\
\hline & 38 & 44 & & & & & & & $16 \mathrm{~m}$ & $9 \mathrm{~cm}$ \\
\hline \multirow[t]{2}{*}{ F/G5 } & 42 & 38 & 40 & 47 & & & & & & \\
\hline & 43 & 42 & 41 & 38 & & & & & $6 \mathrm{~m}$ & $9 \mathrm{~cm}$ \\
\hline F/G7 & 45 & 73 & 47 & 46 & & & & & $3 \mathrm{~m}$ & $27 \mathrm{~cm}$ \\
\hline F/G11 & 58 & 53 & & & & & 57 & 53 & $5 \mathrm{~m}$ & $5 \mathrm{~cm}$ \\
\hline \multirow[t]{3}{*}{ F/G15 } & 66 & 72 & & & & & & & & \\
\hline & 67 & 46 & & & & & & & & \\
\hline & 68 & 60 & & & & & & & $7 \mathrm{~m}$ & $26 \mathrm{~cm}$ \\
\hline \multirow[t]{2}{*}{ F/G16 } & 71 & 32 & 70 & 51 & & & & & & \\
\hline & 73 & 45 & 75 & 72 & & & & & $2 m$ & $40 \mathrm{~cm}$ \\
\hline$F / G 20$ & 76 & 59 & 75 & 72 & & & & & $6 \mathrm{~m}$ & $13 \mathrm{~cm}$ \\
\hline \multirow[t]{2}{*}{$\mathrm{F} / \mathrm{G} 21$} & 78 & 51 & 77 & 49 & & & & & & \\
\hline & 79 & 56 & & & & & & & $8 \mathrm{~m}$ & $7 \mathrm{~cm}$ \\
\hline H1M1/G1 & & & & & 9 & 16 & 10 & 46 & $4 \mathrm{~m}$ & $30 \mathrm{~cm}$ \\
\hline \multirow[t]{9}{*}{$\mathrm{H} 2 / \mathrm{G} 1$} & 15 & 113 & $17 \mathrm{a}$ & 85 & & & & & & \\
\hline & 16 & 80 & 19 & 55 & & & & & & \\
\hline & $17 \mathrm{~b}$ & 79 & & & & & & & & \\
\hline & $17 c$ & 80 & & & & & & & & \\
\hline & $17 d$ & 87 & & & & & & & & \\
\hline & $18 \mathrm{a}$ & 62 & & & & & & & & \\
\hline & $18 \mathrm{~b}$ & 74 & & & & & & & & \\
\hline & 20 & 61 & & & & & & & & \\
\hline & 21 & 68 & & & & & & & $4 \mathrm{~m}$ & $58 \mathrm{~cm}$ \\
\hline H2/G3 & & & 24 & 24 & 25 & 30 & & & $2 \mathrm{~m}$ & $6 \mathrm{~cm}$ \\
\hline \multirow[t]{3}{*}{ H3/G1 } & 11 & 32 & & & & & & & & \\
\hline & 12 & 42 & & & & & & & & \\
\hline & 13 & 36 & & & & & & & $2 \mathrm{~m}$ & $10 \mathrm{~cm}$ \\
\hline \multirow[t]{3}{*}{$\mathrm{L} 1 / \mathrm{G} 1$} & 33 & 58 & 34 & 68 & & & & & & \\
\hline & 35 & 47 & 36 & 60 & & & & & & \\
\hline & 39 & 53 & & & & & & & $1 \mathrm{~m}$ & $21 \mathrm{~cm}$ \\
\hline \multirow[t]{4}{*}{ L6/G1 } & 2 & 54 & & & & & & & & \\
\hline & 3 & 54 & & & & & & & & \\
\hline & 6 & 38 & & & & & & & & \\
\hline & 7 & 45 & & & & & & & $5 \mathrm{~m}$ & $16 \mathrm{~cm}$ \\
\hline \multirow[t]{2}{*}{ L6/G4 } & 29 & 36 & 27 & 31 & & & & & & \\
\hline & & & 28 & 30 & & & & & $2 \mathrm{~m}$ & $6 \mathrm{~cm}$ \\
\hline \multirow[t]{4}{*}{ L6/G8 } & 50 & 53 & 53 & 56 & & & & & & \\
\hline & 51 & 55 & 54 & 62 & & & & & & \\
\hline & 52 & 51 & 55 & 50 & & & & & & \\
\hline & 56 & 53 & & & & & & & $4 \mathrm{~m}$ & $12 \mathrm{~cm}$ \\
\hline \multirow[t]{5}{*}{ L6/G11 } & 60 & 27 & 62 & 48 & & & & & & \\
\hline & 61 & 32 & & & & & & & & \\
\hline & 63 & 40 & & & & & & & & \\
\hline & 64 & 30 & & & & & & & & \\
\hline & 65 & 40 & & & & & & & $5 \mathrm{~m}$ & $21 \mathrm{~cm}$ \\
\hline & & & & & Avers & eparati & etwee & tures & $4.88 \mathrm{~m}$ & $18.58 \mathrm{~cm}$ \\
\hline
\end{tabular}




\section{ARTIFACT ANALYSIS}

Middle and Late Archaic points comprise 70 percent of the recovered projectile points $(n=17)$. These point types are considered together in this discussion because, with the exception of one Pedernales point (UI 32) recovered from the top $10 \mathrm{~cm}$ of Gradall trench M3/G1 in the central portion of the plowed field, these points all came from excavation units or Gradall trenches associated with or adjacent to the two dense concentrations of fire-cracked rock identified as the north and west burned-rock midden deposits at 41BX47 (Table 10).

The 11 diagnostic points associated with the burned rock midden in the north section of the site include three Pedernales, three Kinneys, two Marcos, one Bulverde, one Nolan-like, and one Marshall. One of the Late Archaic points (UI 40) and two of the Middle Archaic points (UI 35 and UI 41) were recovered from the upper $20 \mathrm{~cm}$ in tests units excavated in $10-\mathrm{cm}$ levels within the northern burned rock concentration. The remaining Middle and Late Archaic points were recovered from among the accumulation of firecracked rocks revealed in Gradall trenches $\mathrm{M} 2 / \mathrm{G} 2, \mathrm{H} 2 / \mathrm{G} 2$, and $\mathrm{H} 2 / \mathrm{G} 3$. These depths are less precise but range from approximately 10-28 $\mathrm{cm}$ bs. No distinction could be made between Middle and Late Archaic deposits in the northern midden.

No diagnostic points were recovered in direct association with Feature 9, the western midden accumulation of fire-cracked rocks in trench $\mathrm{H} 1 \mathrm{M} 1 / \mathrm{G} 1$. However, the one Late Archaic Marcos point (UI 34) recovered from the surface at the southwest edge of $\mathrm{H} 1 \mathrm{M} 1 / \mathrm{G} 1$ where the western midden was exposed and the one Bulverde, two Pedernales, and one Pandora also found in Gradall fill dirt from nearby trenches M1L3/G1 and F/G21 located $40 \mathrm{~m}$ and $50 \mathrm{~m}$ respectively from Feature 9 indicate this firecracked feature is also associated with Middle and Late Archaic period use.

Table 10. Middle and Late Archaic Projectile Points Associated with Burned Rock Midden Features

\begin{tabular}{|c|c|c|c|c|c|c|c|}
\hline \multicolumn{4}{|c|}{ North Burned Rock Midden } & \multicolumn{4}{|c|}{ West Burned Rock Midden } \\
\hline UI \# & Type & Location & Depth & UI \# & Type & Location & Depth \\
\hline 22 & Pedernales & $\mathrm{M} 2 / \mathrm{G} 2$ & $24-28 \mathrm{~cm}^{*}$ & 20 & Pedernales & M1L3/G1 & $50 \mathrm{~cm}^{*}$ \\
\hline 23 & Bulverde & $\mathrm{M} 2 / \mathrm{G} 2$ & $24-28 \mathrm{~cm}^{*}$ & 24 & Bulverde & M1L3/G1 & $32 \mathrm{~cm}^{*}$ \\
\hline 21 & Nolan-like & $\mathrm{M} 2 / \mathrm{G} 2$ & $24-28 \mathrm{~cm}^{*}$ & 27 & Pedernales & M1L3/G1 & Surface \\
\hline 29 & Kinney & $\mathrm{M} 2 / \mathrm{G} 2$ & $12-16 \mathrm{~cm}^{*}$ & 34 & Marcos & $\mathrm{H} 1 \mathrm{M} 1 / \mathrm{G} 1$ & Surface \\
\hline 25 & Kinney & $\mathrm{H} 2 / \mathrm{G} 2$ & $10-20 \mathrm{~cm}^{*}$ & 45 & Pandora & $\mathrm{F} / \mathrm{G} 21$ & $56 \mathrm{~cm}^{*}$ \\
\hline 26 & Marcos & $\mathrm{H} 2 / \mathrm{G} 2$ & $10-20 \mathrm{~cm}^{*}$ & \multirow{6}{*}{\multicolumn{4}{|c|}{ * indicates approximate depth }} \\
\hline 28 & Pedernales & $\mathrm{H} 2 / \mathrm{G} 2$ & $10 \mathrm{~cm}^{*}$ & & & & \\
\hline 33 & Pedernales & $\mathrm{H} 2 / \mathrm{G} 3$ & $20 \mathrm{~cm}^{*}$ & & & & \\
\hline 35 & Kinney & $\mathrm{H} 2 / \mathrm{U} 1$ & $9.5 \mathrm{~cm}$ & & & & \\
\hline 40 & Marcos & $\mathrm{H} 2 / \mathrm{U} 4$ & $10-20 \mathrm{~cm}$ & & & & \\
\hline 41 & Marshall & $\mathrm{M} 2 / \mathrm{U} 1$ & $0-10 \mathrm{~cm}$ & & & & \\
\hline
\end{tabular}


The four Early Archaic point types found during this phase of testing were recovered from depths greater than $30 \mathrm{~cm}$ bs (Table 11). UI 30, the Hoxie-like point, and UI 37, an Early Cornernotched point, came from the northern section of the site from between $30-35 \mathrm{~cm}$ bs. UI 36 , the Gower, also came from the northern section of the site. The depth of the Gower $(110 \mathrm{~cm} \mathrm{bs})$ is greater than the other Early Archaic diagnostics, but this is an area that represents an infilled channel and deposition rates are much greater here than in other portions of the site. UI 42, the second Early Archaic point was found in the eastern section of the site at an approximate depth of $45 \mathrm{~cm}$ bs in the B Horizon which contained the majority of the hearth features.
The Late Paleoindian projectile points occur in greatly differing depositional contexts (Table 12). Two Angostura points were recovered from fairly shallow gravel deposits (UI 43 from $45 \mathrm{~cm}$ bs and UI 31 from $51 \mathrm{~cm} \mathrm{bs)} \mathrm{in} \mathrm{the} \mathrm{T3} \mathrm{terrace.}$ These data strongly suggest that deposition rates on the T3 terrace were very slow or that a significant portion of the deposit representing a substantial period time is missing. A single Angostura point (UI 39) was recovered from 125 $\mathrm{cm}$ bs in $\mathrm{H} 2 / \mathrm{U} 2$, stratified below an Early Archaic projectile point (Gower, see above). This indicates that a clear deposition sequence is present in the area around $\mathrm{H} 2 / \mathrm{U} 2$.

Table 11. Early Archaic Projectile Point Distributions

\begin{tabular}{|c|c|c|c|}
\hline UI \# & Type & Location & Depth \\
\hline UI 30 & Hoxie-like & H2/U1 & $32 \mathrm{~cm} \mathrm{bs}$ \\
\hline UI 36 & Gower & H2/U2 & $110 \mathrm{~cm}$ bs \\
\hline UI 37 & Early Corner-notched & H2/G3 & $30-35 \mathrm{~cm}$ bs* \\
\hline UI 42 & Early Comer-notched & F/G15 & $46 \mathrm{~cm}$ bs* \\
\hline
\end{tabular}

* indicates approximate depth

Table 12. Late Paleoindian Projectile Point Distributions

\begin{tabular}{|c|c|c|c||}
\hline UI \# & Type & Location & Depth \\
\hline 31 & Angostura & H1M1/G1 & $51 \mathrm{~cm} \mathrm{bs}^{*}$ \\
\hline 39 & Angostura & H2/U2 & $125 \mathrm{~cm} \mathrm{bs}$ \\
\hline 43 & Angostura & F/G16 & $44-45 \mathrm{~cm} \mathrm{bs}^{*}$ \\
\hline
\end{tabular}

* indicates approximate depth 
Figure 22 illustrates the stratigraphic relationships of the Paleoindian, Early Archaic, and Middle to Late Archaic components as reflected by the diagnostics from these time periods. The Late Paleoindian materials are from gravels except in $\mathrm{H} 2 / \mathrm{U} 2$ where the Early Archaic and Paleoindian components are substantially deeper than in other parts of the site. Here, sediments have accumulated to a greater thickness and the sedimentation rate(s) appear to have been higher in relation to the remaining portion of the site, especially the $\mathrm{T} 4$ terrace (Unit II deposit).

\section{SPATIAL ANALYSIS}

Although all areas of the site were investigated by Gradall trench excavation, the majority of the hearth features are distributed in three horizontal clusters that correspond with the high, medium, and low artifact density sample areas identified in the research design (Figures 2 and 3 ). These horizontal clusters can be used to divide the site into archaeologically more meaningful units (Figure 23).

One cluster is on the $\mathrm{T} 3$ terrace corresponding with the H1, M1, L3, and L1 sample areas and, for this discussion, is called the West Section. Two clusters are on the T4 terrace; North Section which corresponds to sample areas $\mathrm{H} 2$ and M2, and the East Section which is in the H3M3 sample area. Correlations can be seen when the vertical distribution of artifacts from test units in these sections is compared with the depth of features revealed in nearby trenches.

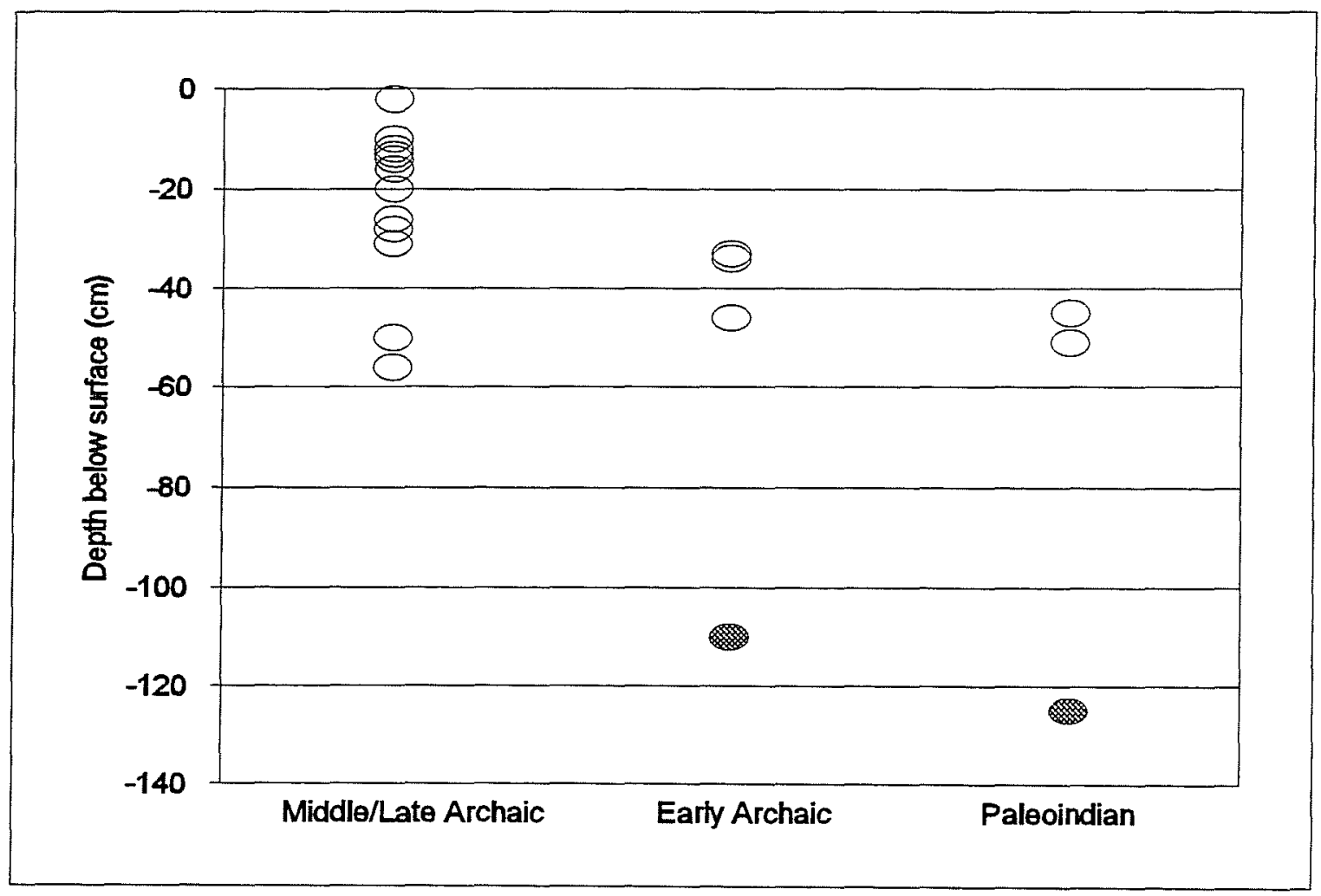

Figure 22. Vertical distribution of diagnostic points. Solid circle indicates points from unit H2/U2. 
This page has been

redacted because it

contains restricted

information. 
In the East Section (Figure 24) three 1-x-1-m units were excavated and the distribution of artifacts indicates a peak in all units between $40-50 \mathrm{~cm}$ bs in the Bk horizon. Gravels were encountered and excavations ceased between $60-70 \mathrm{~cm}$ bs in unit $\mathrm{H3} / \mathrm{U} 1$ and between $50-60 \mathrm{~cm}$ bs in unit M3/U1. A feature was encountered between $50-60 \mathrm{~cm}$ bs in unit $\mathrm{M} 3 / \mathrm{U} 2$ and excavations ceased (see Table 5). Feature distribution follows a similar pattern, peaking between $50-60 \mathrm{~cm}$ bs immediately above the gravels. This correlation fits the geomorphological pattern of continuous, rapid aggradation without extended periods of stable surface exposure suggested for the T4 terrace. No diagnostic points were recovered in direct association with these units or features in the East Section of 41BX47. However, an Early Archaic time span can be assumed for this component based on Early Archaic points recovered from the $\mathrm{Bk}$ horizon in other parts of the site and the stratigraphic

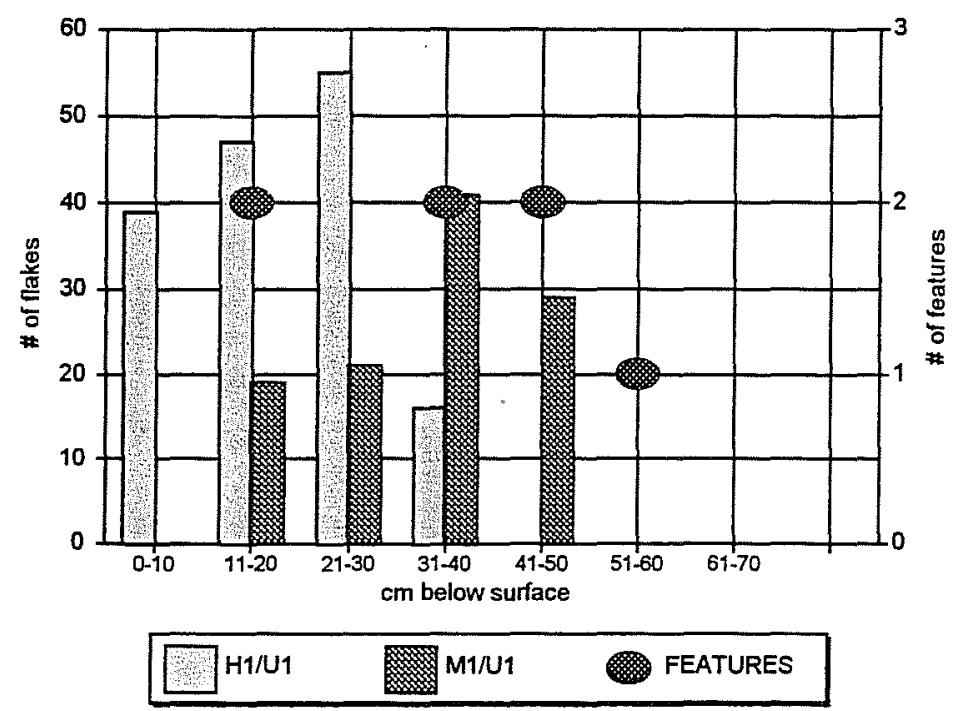

Figure 25. Vertical distribution of artifacts and features in the West Section. location of the Bk horizon between the radiocarbon-dated Middle Archaic component above and the Late Paleoindian component below.

In the West Section (Figure 25) the highest artifact counts occur in the $20-30 \mathrm{~cm}$ range in unit $\mathrm{H} 1 / \mathrm{U} 1$ and in the $30-40 \mathrm{~cm}$ range in $\mathrm{M} 1 / \mathrm{U} 1$. Excavations in these two units were terminated between $40-50 \mathrm{~cm}$ and $50-60 \mathrm{~cm}$, respectively, because features were encountered. Gravels encountered between $60-70 \mathrm{~cm}$ bs in nearby trenches however, provide a limit for cultural deposits in this area. Feature depths reflect a weak bimodal distribution with two features occurring between $11-20 \mathrm{~cm}$ and two more between $31-50$ $\mathrm{cm}$. This bimodal patterning, combined with the Middle to Late Archaic diagnostic artifacts recovered in the West Section, indicate that features in this portion of the site are associated with activities from these two time periods. 
In the North Section the excavation units display a variety of artifact depth distributions. In units $\mathrm{H} 2 / \mathrm{U} 3$ and $\mathrm{H} 2 / \mathrm{U} 4$ near the northern burned rock midden, artifacts peak between $0-20 \mathrm{~cm}$ below surface while artifacts in unit M2/U1, also associated with the midden are evenly distributed between $0-40 \mathrm{~cm}$. These depths correspond with the depths recorded for the three features which make up the burned rock midden in the upper

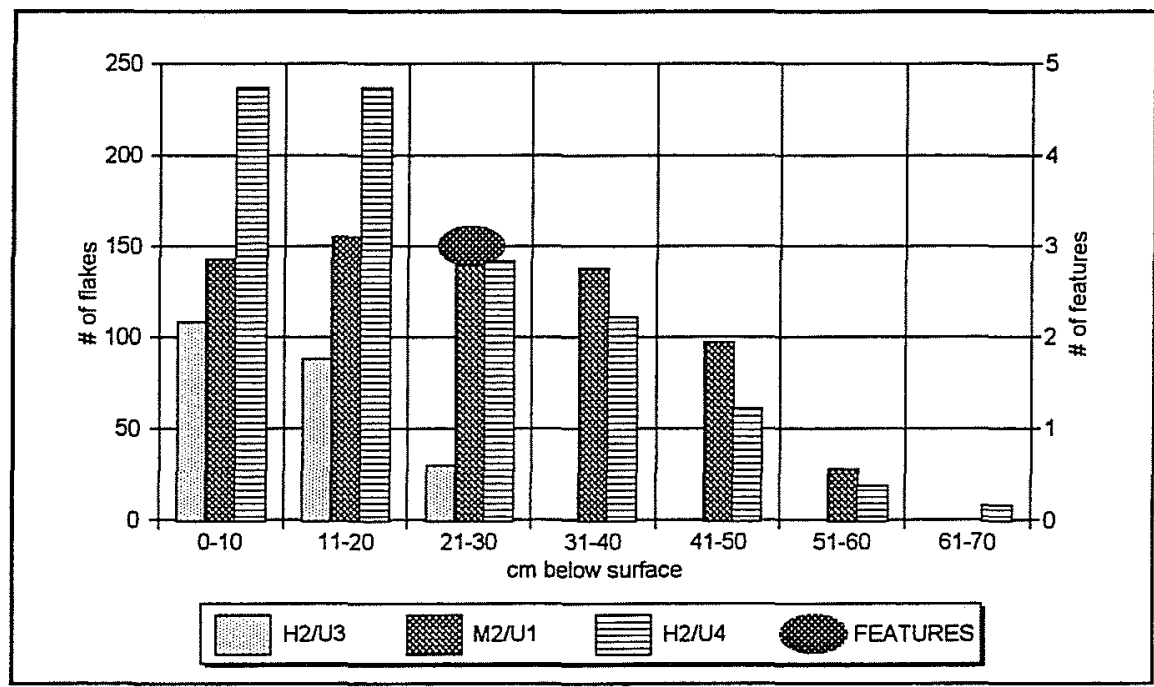

Figure 26. Vertical distribution of artifacts and features in the upper levels of the North Section. levels of the north part of the site and are associated with numerous Middle and Late Archaic points (Figure 26).

Unit H2/U1 (Figure 27) displays a bimodal artifact distribution. The peak between $11-20 \mathrm{~cm}$ corresponds with the depth of the nearby midden features at 21-30 $\mathrm{cm}$ (Figure 26). The second peak between $51-70 \mathrm{~cm}$ corresponds with the hearth features in trench $\mathrm{H} 2 / \mathrm{G} 1$ (Figure 27). The peak in artifact frequency in Unit H2/U2 occurs between $121-130 \mathrm{~cm}$ bs where the Late Paleoindian period Angostura projectile point was recovered in association with two hearth features. Paleoindian, Early Archaic, and Middle to Late Archaic components are represented in this section of the site.

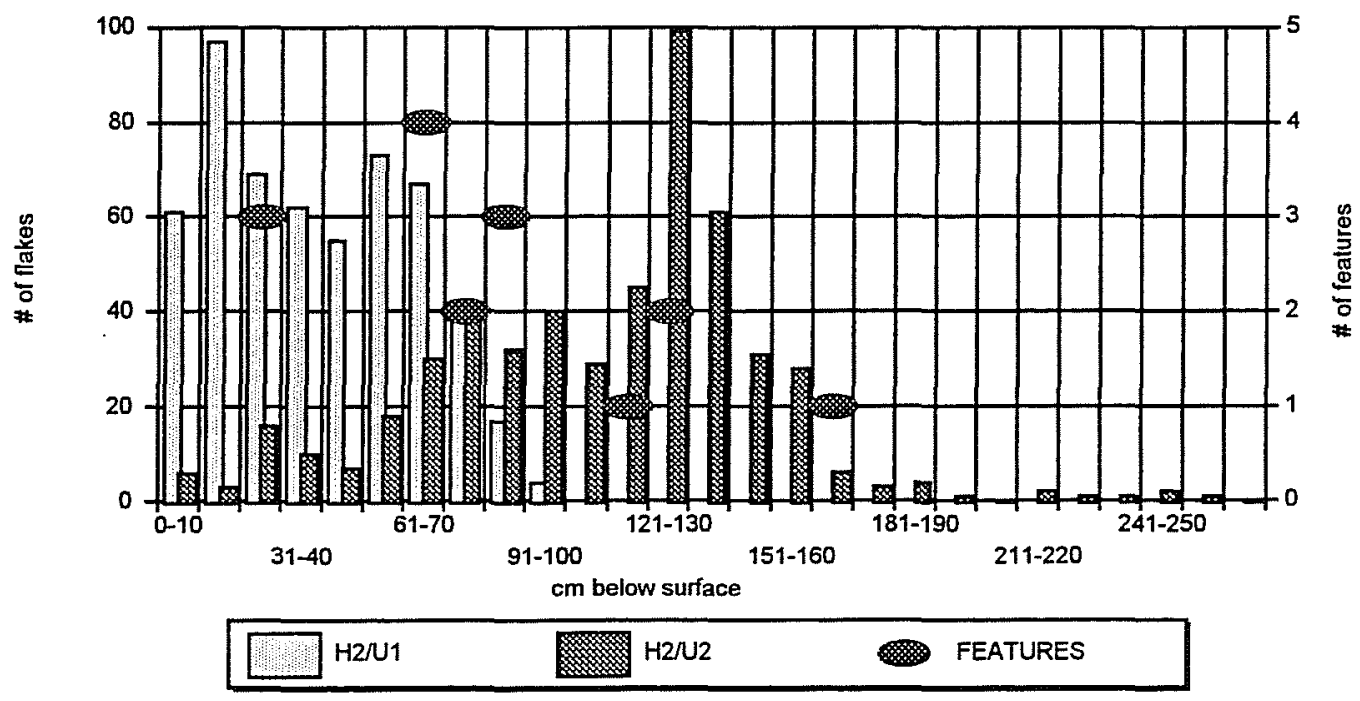

Figure 27. Vertical distribution of artifacts and features in the lower levels of the North Section. 


\section{SUMMARY}

The 84 burned rock features uncovered at $41 \mathrm{BX} 47$ are intact cultural remnants of prehistoric occupations. Minimum investigations uncovered in situ lithic artifacts associated with 55 of the 84 features and conjoins (burned rocks cracked in place) were recorded in 40 of these feature, evidence of the undisturbed nature of these deposits. Analysis of archaeomagnetic samples from one burned rock feature (Feature 49) indicates that these rocks cooled in place (see Appendix $\mathrm{C}$ for details), further supporting the interpretation that these features remain in their original archaeological context.

Analyses of these features reveal distinct patterns of horizontal and vertical distribution. The large midden features occur exclusively in the top $10-30 \mathrm{~cm}$ of the $A$ horizon in the north and northwest sections of the site. Hearths, ovens, and burned-rock scatters are consistently found at levels below the $A$ horizon in the south and southwest sections of the site. These features occur primarily between 30 and $60 \mathrm{~cm}$ bs in the B horizon, suggesting an earlier deposit is present across much of the site. Further, patterns of vertical separation of features within a single trench suggest many of the hearth features may be the result of contemporaneous use, an interpretation supported by the geomorphological evidence for rapid aggradation of the Bk horizon in which many of these features are found (Nordt this volume).

Patterns are also revealed by feature size and composition comparisons. Middens are the largest feature type, containing in excess of 200 rocks each. One midden at $41 B \times 47$ may cover a $30-x-50-m$ area. Oven features, with less than 100 rocks, are smaller than midden features yet larger than hearth/scatter features. Forty-one percent $(n=16)$ of the hearths are less than .5 $\mathrm{m}^{2}$, in area and over 80 percent of the hearth/scatter features are composed of fewer than 35 burned rocks.

Such differences in feature size have been related to functional differences. Collins (1991),
Greer (1968), Johnson (1991), Thoms (1989), and Weir (1976) suggested that large accumulations of burned rock like the midden features at 41BX47 represents intensification or bulk processing of vegetal foodstuffs for large groups of people. The volume of burned rock present in these features reflects discards from either stone-boiling procedures (Collins 1991) or overlapping reuse of hearths and ovens (Black 1995; Honea 1962). Temporally diagnostic projectile points from within the two midden deposits and adjacent test units and a radiocarbon date of 5235- 4850 B. P. indicate these features were used primarily during the Middle Archaic period and to a lesser extent during the Late Archaic period. These findings further support the current perception that burned rock middens represent a specialized economic adaptation for seasonal harvesting of large wild crops for larger Middle Archaic populations (Black 1989; Collins 1991; Creel 1986; Weir 1976).

Ovens are described in ethnographic studies as features used by a number of families or a whole community for processing of agave or other food stuffs (Driver and Massey 1957). Johnson (1991) refers to "baking heap" features at the Early Archaic Sleeper site that are similar to the oven two features at 41BX47. He concludes, based on the size of the individual rocks, that these accumulations were actual cooking features and not piles of rock used in stone boiling. He proposes that food was cooked among these rocks after they had been heated. The stones in our oven features are $10-35 \mathrm{~cm}$ in diameter also appear to be too large for stone boiling. While no temporally diagnostic projectile points were found in association with either of these features, they do occur in the same strata as the Early Archaic materials from the site. Understanding the formation processes and functions of the features classified as ovens must await further investigation.

Small hearths/scatters were the most frequent feature type encountered at 41BX47 $(n=79)$. Virtually all of these features (94 percent, $n=73$ ) were found in stratigraphic levels associated with Early Archaic or Paleoindian projectile points; 
the radiocarbon date of 8955 (8655) 8545 в. P. was obtained from the deepest of these features. Small cooking features similar to these are associated with smaller groups of people processing lesser amounts of food. Meat was most frequently broiled on stakes or horizontal frames suspended over small hearth fires or roasted directly on heated stones beside small fires. Hot stones were also used as direct sources of heat for baking (Driver and Massey 1957). Collins et al. (1990) found evidence of both plant and animal lipids in organic residue analysis of small hearth features at the Camp Pearl Wheat site. Further archaeological data from hearths and scatters like the ones at 41BX47 need to be systematically collected and analyzed to better understand the function and formation.

Although the burned rock feature density is low ( $31.9 \mathrm{sq} \mathrm{m}$ per feature), the size of the site is extremely large (approximately $150,000 \mathrm{sq} \mathrm{m}$ ). A great number of burned rock features likely exist at the site (roughly a total of 4,700 features for the entire site as 1.7 percent of the site was excavated by Gradall during the testing phase of investigations). Projectile point numbers are also low (3 Late Archaic, 14 Middle Archaic, 4 Early Archaic, and 3 Late Paleoindian forms). However, most of these were recovered during Gradall operations from sediments that were not systematically screened.

The differences in the horizontally and vertically discrete Paleoindian, Early Archaic, and MiddleLate Archaic components at 41BX47 represent organizational adaptations to economic, demographic, and environmental changes through time along the terraces of upper Leon Valley Creek. Without question the site offers important avenues for investigating the historic context concerned with prehistoric adaptations and subsistence. 


\title{
CHAPTER 6: HISTORIC CONTEXT AND RECOMMENDATIONS
}

\author{
Robert J. Hard and C. Britt Bousman
}

\section{REVIEW OF PERTINENT ARCHAEOLOGICAL STUDIES}

Several recently excavated sites from central Texas have well studied burned rock features that can be compared to the burned rock features at 41BX47. Archaeologists now know that burned rock middens and smaller features occur in the Early, Middle, and Late Archaic and Late Prehistoric periods (Collins et al. 1993; Goode 1991; Howard 1991). The nature of these burned rock features has been a subject of intense archaeological investigations over the last few years in central Texas (Creel 1986; Collins et al. 1990; Hester 1991; Johnson 1991; Potter and Black 1995; Potter et al. 1995; Thoms 1992) and various new methods and theoretical approaches are being aimed at this seemingly intractable but abundant source of archaeological data. The following is a brief review of the most important recent studies that have focused on Early Archaic burned rock features in central Texas.

Excavation of two small blocks ( $60 \mathrm{sq} \mathrm{m}$ and 16 sq m) at Camp Pearl Wheat (41KR243) revealed a thin discrete Early Archaic component with six small, circular to oval burned rock features (12.7 sq $\mathrm{m}$ per hearth) buried in an early Holocene terrace (Collins et al. 1990). Twelve burned rock samples from hearths were submitted for archaeomagnetic analysis. The results indicate that some of the features had cooled in place and that some of the rocks had been heated more than once or moved while cooling. The small size of the terrace and the known size of the site ( $9600 \mathrm{sq} \mathrm{m}$ ) places a limit on the number of possible hearths.

The Sleeper Site (41WM235) is an Early Archaic site in a low terrace of West Walnut Creek in Blanco County (Johnson 1991). Approximately $86 \mathrm{sq} \mathrm{m}$ were excavated, mostly in a single block. A fairly dense scatter of buried burned rock was subdivided into at least 10 large features called baking heaps, and 3 small features called hearths (no more than $6.6 \mathrm{sq} \mathrm{m}$ per burned rock feature). Johnson (1991) suggests that most of the site was excavated. A large number of grinding stones (38 individual metates, 70 manos), but a small number of projectile points were found at the site.

Numerous Early Archaic burned rock features were excavated at 41WM235, the WilsonLeonard site (Collins et al. 1993). Large burned rock ovens used to cook plant and animal foods were found in the zone dating to ca. 8000 B.P. After the food was cooked the ovens were opened and many of the rocks scattered randomly while some remained in place. Thirtysix smaller hearths are also present this level. In the overlying Early Archaic zone fewer burned rock features are present (13 total), they are much smaller in size, and less dense ( $2.5 \mathrm{sq} \mathrm{m}$ per feature). Throughout the sequence at WilsonLeonard, projectile points are one of the most common tool type and grinding stones are one of the least common tool types (Bousman and Collins 1994). It is extremely difficult to project or estimate the size of the Early Archaic components at the Wilson-Leonard site as these components are deeply buried and few surface indications exist from which to estimate their size.

\section{CONCLUSIONS}

Site $41 \mathrm{BX} 47$ appears unique from the reviewed sites which have high feature densities but total projected number of features for those sites is much lower than the estimates at 41BX47 (Table 13). This site represents a unique set of attributes: feature density is but total number of projected features is astonishingly high; the ratio of projectile points features is very low, and the 
Table 13. Density of Features and Number of Projectile Points and Grinding Stones

Per Feature at Selected Early Archaic Sites

\begin{tabular}{||l|c|c|c|c|c||}
\hline \multicolumn{1}{|c|}{ Site } & $\begin{array}{c}\text { Square meters } \\
\text { per feature }\end{array}$ & $\begin{array}{c}\text { Estimated } \\
\text { total } \\
\text { features }\end{array}$ & $\begin{array}{c}\text { Ratio of } \\
\text { points } \\
\text { per feature }\end{array}$ & $\begin{array}{c}\text { Ratio of } \\
\text { Ground } \\
\text { stone } \\
\text { per feature }\end{array}$ & $\begin{array}{c}\text { Ratio of ground } \\
\text { stone/projectile } \\
\text { point }\end{array}$ \\
\hline Camp Pearl Wheat & 12.7 & 755 & 1.2 & 0 & 0 \\
\hline Sleeper Site & 6.6 & $20-30$ & 1.5 & 8.3 & 568 \\
\hline Wilson-Leonard Imb & 2.5 & 1015 & 7.2 & 0.5 & 7.4 \\
\hline Wilson-Leonard III & 0.9 & 2800 & 2.3 & 0.4 & 14.4 \\
\hline 41BX47 & 31.7 & 4700 & 0.3 & 0 & 0 \\
\hline
\end{tabular}

ratio of ground stone implements to projectile points is very low also. The many small Early Archaic features and the two large Middle Archaic features provide a unique temporal contrast in feature function amd formation process not normally found in one site. It is unclear why the ratio of ground stone implements to projectile points at $41 \mathrm{BX} 47$ is so low, or why the ratio of projectile points to features is so low, but in an unpublished study Bousman and Skinner (1983) suggest that projectile point discard rates are related to bison population fluctuations in west Central Texas. It is possible that the many small Early Archaic hearths and ovens at 41BX47 represent a period when subsistence was not focused on bison but rather on small game and plants.

\section{HISTORIC CONTEXTS}

Archaeological sites are evaluated according to Section 106 of the National Historic Preservation Act based upon the concept of significance. In order for a site to be considered significant it must have the potential for contributing knowledge to research questions. Ideally, fully developed research questions are published, shared, and discussed among the archaeological and preservation community. Historic contexts provide an objective means by which archaeological sites can be evaluated. Furthermore, historic contexts facilitate common research goals among diverse organizations, and preclude the need for each project to independently derive every pertinent historic context and research question.

Unfortunately, the only regional historic context which has been published by the Texas Historic Commission thus far is for eastern Texas (Kenmotsu and Perttula 1993), although others are in the planning stages. Fortunately, Potter et al. (1995) developed two historic contexts for prehistoric sites in the San Antonio area which are clearly applicable to the investigations at 41BX47. The first historic context developed by Potter et al. (1995) considers prehistoric human lifeways or adaptations; the second concerns past environmental change. The following discussion will utilize and address the historic contexts developed by Potter et al. (1995), and elaborate when needed.

\section{PREHISTORIC ADAPTATIONS AND SUBSISTENCE}

The first historic context applicable to the investigations at $41 \mathrm{BX} 47$ concerns prehistoric human adaptation and subsistence (Potter et al. 1995). Many hundreds of generations of Native American hunters and gatherers utilized the 
south Texas landscape over the last 11,000 years. Anthropologists who have studied living hunter and gatherer societies around the world know that hunter-gatherer lifeways are intimately related to the types of natural resources they use and the manner in which they exploit these resources. For example, hunters and gatherers who harvest and store many hundreds of pounds of plant foods for the winter will organize themselves very differently from a group which relies largely on bison hunting. Archaeologists suspect that Native American adaptations to the south Texas region changed over the course of the millennia as the environment and populations shifted, but our substantive knowledge, particularly of the time periods represented at 41BX47, is minimal.

The research questions that are part of this historic context involve identifying the food and material resources that were used and, of at least equal importance, how they were utilized. The data needed to address these questions can be derived from detailed examination of the characteristics of burned rock features, spatial analysis of these burned rock features and their associated artifacts, life-history analysis of stone tools, and recovery of archaeological plant and bone samples.

\section{Burned Rock Features}

Detailed examination of burned rock features yields significant data concerning their formation, use, and abandonment. The extraordinarily large number of features uncovered at $41 B X 47$, the variety of their forms (middens, ovens, hearths and scatters), and their excellent preservation and integrity in a buried alluvial setting provide an unique archaeological resource in the region. While one form of these features, the burned rock midden, has received considerable attention by archaeologists, its function and formation are still debated (Collins 1991; Creel 1986; Howard 1991; Kelley and Campbell 1942; Peter 1982). Burned rock middens dating throughout the Archaic and Late Prehistoric periods have been identified in central Texas, they typically have been thought to peak in use during the Middle Archaic (Prewitt 1981; Weir 1976). At 41BX47, hearths and ovens are associated with Early Archaic components and hearths with a Late Paleoindian component. However, burned rock middens appear to be associated only with Middle and Late Archaic artifacts despite the presence of extensive Early Archaic occupations, a pattern which would have direct bearing on interpreting changes in prehistoric adaptations. In order to understand the significance of burned rock features, their formation, use, abandonment, and reuse must be investigated.

Since the 1940s the occurrence of middens has been explained by utilizing site formation and function arguments (Creel 1986; Kelley and Campbell 1942; Peter 1982). Kelley and Campbell's (1942) still valid but untested model suggested that middens were accretional and formed over a long period of time from the continued use of small burned rock features (hearths) on non-aggrading surfaces. Numerous middens have been excavated in central Texas (Howard 1991) and in many cases they occur in areas with low sediment deposition rates or in areas with no sedimentation. As Collins (1991:15) suggests, if all middens occurred in these areas then the deposition formation model for middens would be favored but not proven. The context at $41 \mathrm{BX} 47$ is one of moderately rapid deposition during the Late Paleoindian and Early Archaic periods and slowed deposition in the Middle Archaic-aged deposits. A wide variety of burned rock features have been mapped, including small to large hearths, large rock ovens, and burned rock middens. Most features at $41 B \times 47$ are small to large hearths occurring in great numbers in the alluvial matrix. This site represents a unique archaeological data set for central Texas because so many Early Aarchaic hearths and so few Middle Archaic middens are present. The site presents a setting where specific questions concerning burned rock feature function and formation can be addressed. 
One of the most useful techniques used recently for analyzing burned rock features is archaeomagnetic analysis (Cheek et al. 1980; Collins et al. 1990). Limestone contains magnetic minerals in great enough concentrations to allow high resolution measurements. The theory behind this method of analysis is that the magnetic pole is constantly moving, and at times it even flips so that magnetic north is in the southern hemisphere. Usually it meanders slowly and unpredictably around the north pole (known as secular variation). When sediment that eventually becomes limestone is first deposited, most of the magnetic minerals are aligned on the azimuth and dip of the currentmagnetic pole, and the stone retains this original alignment. If a stone is used in a hearth or midden and it is heated to a high enough temperature to relax the original alignment, then the magnetic particles are free to re-align on the new magnetic pole. When the rock cools the particles "freeze" on this new alignment. Until recently these minor wanderings and re-alignments have been used by archaeologists to date features. By knowing the position (azimuth and dip) of the magnetic pole at different periods of time, the magnetic alignment of a feature can be compared to the known wanderings and the age of a heating event estimated.

Additionally, archaeomagnetic analysis allows archaeologists to assess the context of the feature. If a burned rock feature was heated to a high temperature, cooled in place, and never disturbed, then the magnetic alignments of all of the burned rocks should be the same and pointing to the magnetic pole at the time the feature was in use (Figure 28a). If, on the other hand, the accumulation of burned rocks is not an intact burned rock feature but rather a trash dump (secondary disposal area) then the magnetic alignments of the burned rocks will not agree nor will they point in the right direction (Figure 28b). Identifying intact features versus secondary disposal dumps is very important because hunters and gatherers who "camp-out" their entire lives organize their activities around
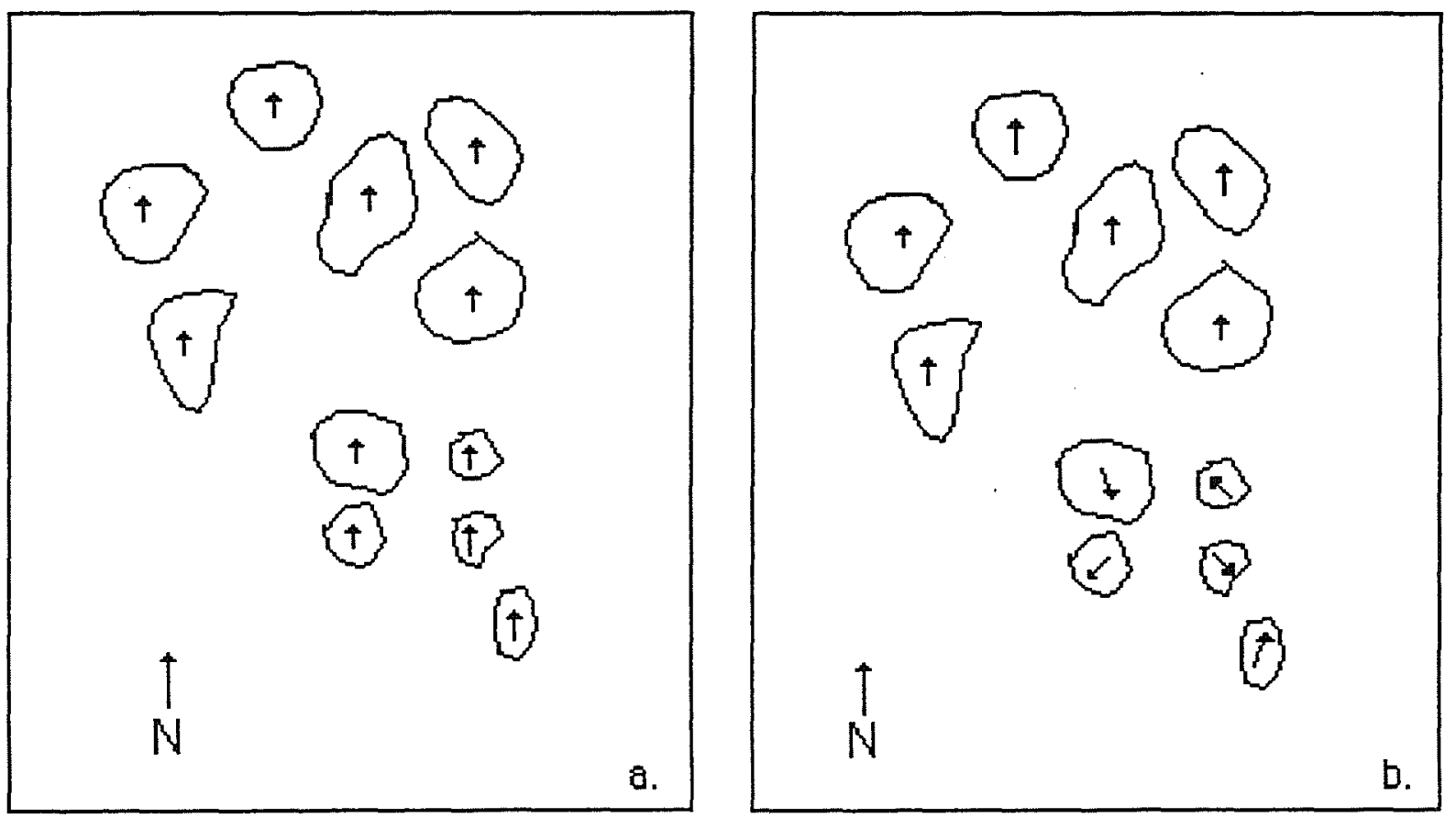

Figure 28. Archaeomagnetic orientations of hypothetical burned rock features. a. intact feature; $b$. burned rock feature with southern cluster of disturbed rocks. 
household hearths, while large cooking ovens may or may not have been located at the periphery. Trash middens are usually placed away from household hearths on the edge of a camp (Bartram et al. 1991; O'Connell 1987; O'Connell et al. 1991; Stevenson 1991; Yellen 1977).

Archaeomagnetic assay also allows for a more sophisticated analysis of the burned rock features by incorporating stepped-heating measurement. This indicates how hot the rocks were heated and if the rocks were heated more than once. These data allow for an assessment of re-use.

Recent applications of archaeomagnetic analyses at $41 \mathrm{BX} 47$ and other locations have resulted in the dissection of prehistoric hearths and ovens (Gose, Appendix C). For example, at the Wilson-Leonard site the tops of Early Archaic cooking ovens are completely disturbed, but portions of the bottoms are intact (Wulf Gose and Paul Takac, personal communications 1995). At Wurzbach Parkway, in San Antonio, intact Middle Archaic hearths were found adjacent to burned rock dumps that represent the refuse created by unpacking a cooking oven (Paul Takac, personal communication 1995). Thus the accurate identification of a hearth or any other burned rock feature is critically important, especially if spatial analysis of a site is planned.

\section{Spatial Organization}

A second source of data that can be used to address the human adaptation and subsistence historic context is the spatial distribution of artifacts and features within the site. Recent archaeological and ethnoarchaeological (archaeology of living societies) research has resulted in a rapidly growing body of knowledge that provides powerful analytic tools that can be used to understand prehistoric lifeways. Numerous studies have developed methods for analyzing and interpreting the spatial patterns of artifacts and other archaeological materials in such settings (Hietala 1984; Kroll and Price
1991; O'Connell 1987). The complex accumulation of burned rock features at $41 B X 47$ may have resulted from a wide range of activities: from brief special purpose activities such as plant exploitation by a small task group, to a seasonally occupied base camp used by a multifamily band, to a special location occupied by multiple bands simultaneously. In fact, all these activities may have occurred at $41 \mathrm{BX} 47$ over the millennia.

Not only can spatial analysis discriminate between these types of site uses, but it may also detect differences in the overall organization of the group. It appears that groups reliant upon larger amounts of stored food (collectors) will have a different camp layout than a group that is not (foragers). For example O'Connell (1987) argues that foragers and collectors produce different site structures. Foragers (e.g. the !Kung Bushmen of the Kalahari and Alyawara Aborigines of Australia) have household clusters at residential camps with little internal complexity, while collectors (e.g., Nunamiut Eskimos of Alaska) have more complex residential camps that are more highly structured. At forager residential sites, research demonstrates that the most important determinants of site structure and size are length of occupation, number of occupants, seasonal variation in weather, degree of food sharing between households, reliance on food storage, and perhaps risk from larger predators (Gargett and Hayden 1991; O'Connell 1987; Whitelaw 1991; Yellen 1977). A critical aspect of this type of research is discriminating between archaeological deposits which are the product of reoccupations and those that are the product of a single occupation. Site $41 B \times 47$ is unique in this regard due to evidence that many of the Early Archaic features were rapidly buried, reducing the likelihood that multiple reoccupations here are collapsed together.

In a complementary study Stevenson (1991) looked at the processes involved in determining artifact distributions around hunter-gatherers' hearths. A series of intentional processes (expedient cleaning, systematic refuse disposal) 
and unintentional processes (scuffage, trampling, and children's play) result in spatial size-sorting of artifacts. Small artifacts are more likely to escape cleaning, secondary removal, or a variety of unintentional processes. Thus smaller items are discarded and remain in the locations of original use (O'Connell 1987; Stevenson 1991). Stevenson (1991) effectively argues that the longer a site is occupied, the greater the degree of size sorting. Keeley (1991), using edge wear analysis and refitting of lithic artifacts, demonstrates this process on a prehistoric site where some artifacts were moved while others remained in the original locus of use. This strategy is well suited to determine the work patterns of hunters and gatherers, although no archaeologists have identified gearing-up or make-and-mend work patterns in a prehistoric setting.

In order for spatial analysis to be conducted, multiple large-block hand-excavations need to be undertaken (O'Connell 1987). The recovery of a diverse artifact assemblage, particularly smaller items, would potentially allow for the identification of significant spatial patterns that can be related to an array of activities and depositional contexts. Additionally other significant features might be exposed such as storage pits or house remains. These are commonly associated with cooking features among ethnographically documented modern hunters and gatherers. Although house remains have yet to be identified in south Texas, they have been found in the Texas coastal area, west central Texas and the lower Plains (Boyd et al. 1993; Ricklis and Gunter 1986; Treece et al. 1993).

\section{Technological Organization}

A third dimension that provides important information for our knowledge of prehistoric human adaptations is the study of how prehistoric hunters and gatherers manufactured, used, maintained, and discarded their stone tools and other technological devices (including cooking features). In recent years, archaeologists have begun to focus on the organization required to construct and use technology. Most effort has focused on extractive tools, especially weapons, but recently more effort has been spent on all tools: extractive and maintenance (Bousman 1993). Furthermore, while cooking features have not been the primary source of data for developing models of technological organization, the central Texas archaeological record suggests that much can be learned from their systematic study and analysis. Primary in this organizationof-technology approach is a concern with the costs and benefits of tools, equipment and facilities.

\section{Capacity Planning for Features}

Recent analysis of intensive plant processing and construction of large cooking features in the northwest U.S. indicates that 1 ) rocks are not necessary for cooking foods for short periods, ca. 24 hours or less, 2) collecting rocks for cooking features requires a great deal of work, and 3) the thermal properties of rock allows for cooking over long periods of time, 24-48 hours, since rock acts as a heating element (Thoms 1989). Review of capacity planning models indicates that as larger and larger packets of food are cooked together, larger and larger cooking features will be constructed in order to reduce the food-per-unit costs of processing. In other words, small amounts of food can be cooked most efficiently in small cooking features, and large amounts of food, perhaps for larger groups of people, can be cooked most efficiently in large cooking features. Thus the size of cooking features like those at $41 \mathrm{BX} 47$ is a proxy measure of the amount of food cooked in those features. This relationship is illustrated in Figure 29 where the unit-cost function of processing food in a medium-sized feature (e.g. large hearth) is shown on the middle curve. The most efficient use of this feature in terms of capacity is shown by point B. Unit costs rise as processing capacity increases or decreases above or below point $B$. If the food capacity increases then at some stage (e.g. point $\mathrm{D}$ on the medium feature curve) it will be more efficient to shift to a larger cooking feature (point $E$ on the large feature curve. Points $A, B$, and $C$ represent the 


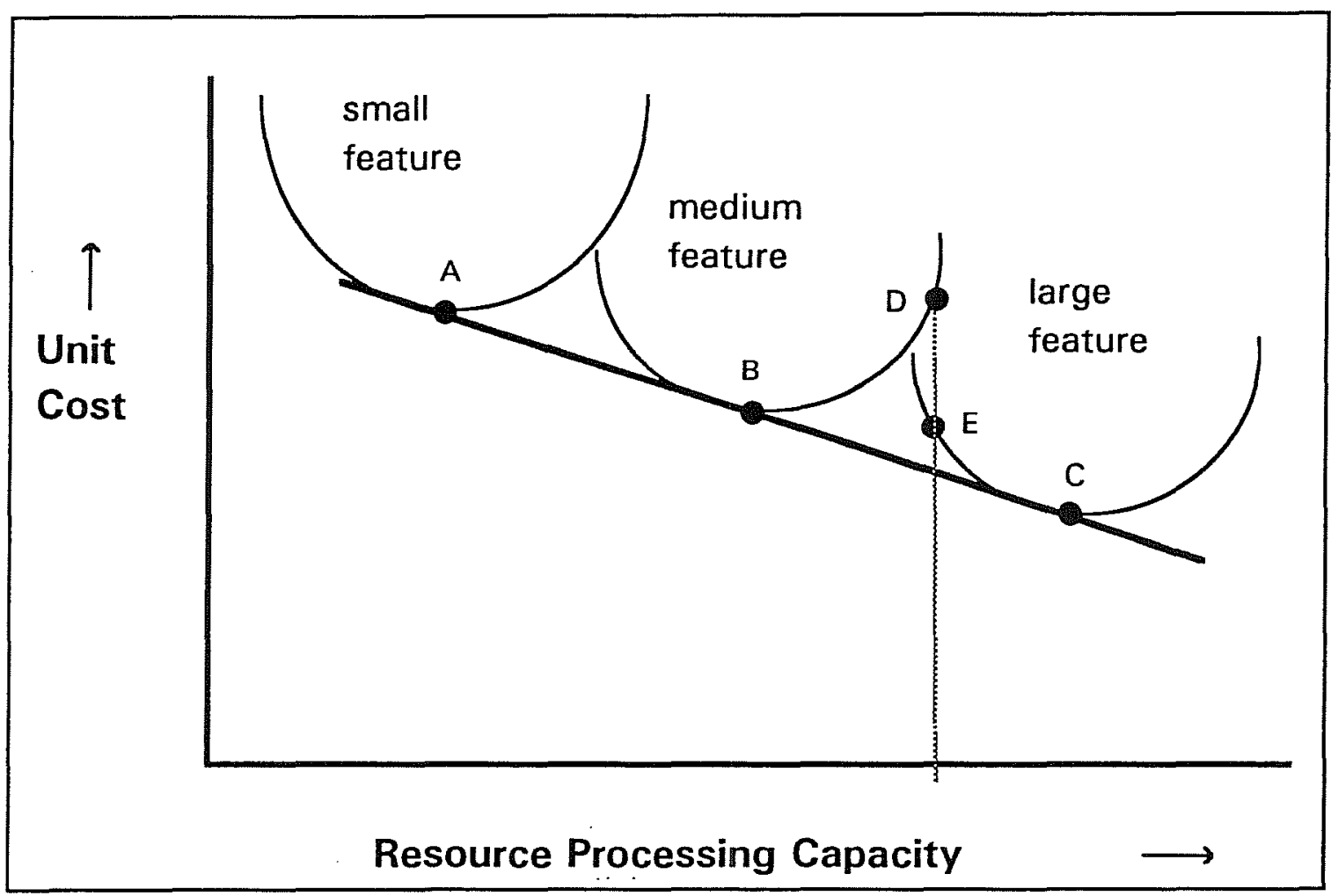

Figure 29. Capacity planning model for prehistoric features.

most efficient use, in terms processing capacities, for the different size features.

The concept of capacity planning for cooking features is important because if hunters and gatherers are exploiting foods in bulk and storing large quantities of food for lean seasons (this is a very important dimension according to current hunter-gatherer theory) then the capacity planning models strongly suggest that evidence should be present in the features. The size of burned rock features also provides proxy evidence on hunter- gatherer group size.

\section{Tool Design, Manufacture,}

Maintenance, Curation and Discard In the last few years archaeologists have discovered that the design, manufacture, and use of artifacts by hunters and gatherers is strongly conditioned by their exploitation patterns. Tools are often manufactured with a balance of three design goals: expediency, reliability, and maintainability (Figure 30 ), and their use reflects their continuing roles in the exploitation of resources (Binford 1973; Bleed 1986; Bousman 1993). This research is important because stone tools are not altered by decay processes after the tool is discarded, and the abundance of stone tools on prehistoric sites makes them a very abundant and ready source of

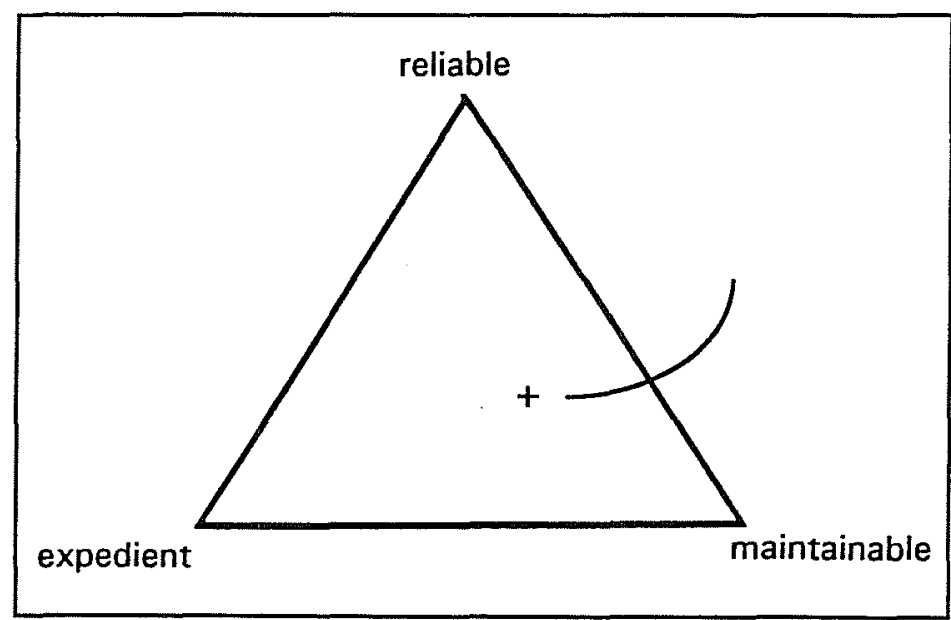

Figure 30. Hypothetical tool's design goals. 
information. In summary this research suggests that hunting and gathering groups (called Collectors) who depend on exploiting resources in bulk and storing large quantities of food, use tools that tend to emphasize reliable and maintainable qualities. The tools used to directly acquire food from the environment (extractive tools) are often complex and specialized, but parts are replaced often if they appear to be at risk of failure. The maintenance tools (tools used to make or maintain other tools) of these groups often are intensively maintained and used until the tools are exhausted. Collectors often manufacture and repair their tools during intensive periods, known as gearing-up sessions, dedicated entirely to technological activities.

At the other end of the spectrum, groups that do not exploit food resources in bulk and do not store food for lean seasons (called Foragers), employ a very different strategy toward their tool manufacture and use. Their extractive tools are intensively maintained and kept in working order as long as possible, while their maintenance tools are often made on the spot and used only for the immediate task. Thus they favor extractive tools that emphasize maintainability, and maintenance tools that emphasize expediency. Repair and replacement occurs sporadically, when and where needed. This pattern of work is called make-and-mend.

Prehistoric tool use seems to be very sensitive to changes in the patterns of resource exploitation (Bousman 1991), because the costs and benefits (often called utility) of tool designs that shift between reliability (high cost, high utility), maintainability (moderate cost, moderate but renewable utility) and expediency (low cost, low utility) are very different for these specific goals (Figure 31). Analysis of lithic artifacts, chipped stone, and ground stone from sites such as $41 \mathrm{BX} 47$ can utilize the concepts of tool design and capacity planning to analyze specific attributes that can provide information on the exploitation of resources by prehistoric hunters and gatherers.

\section{Plant and Bone Recovery}

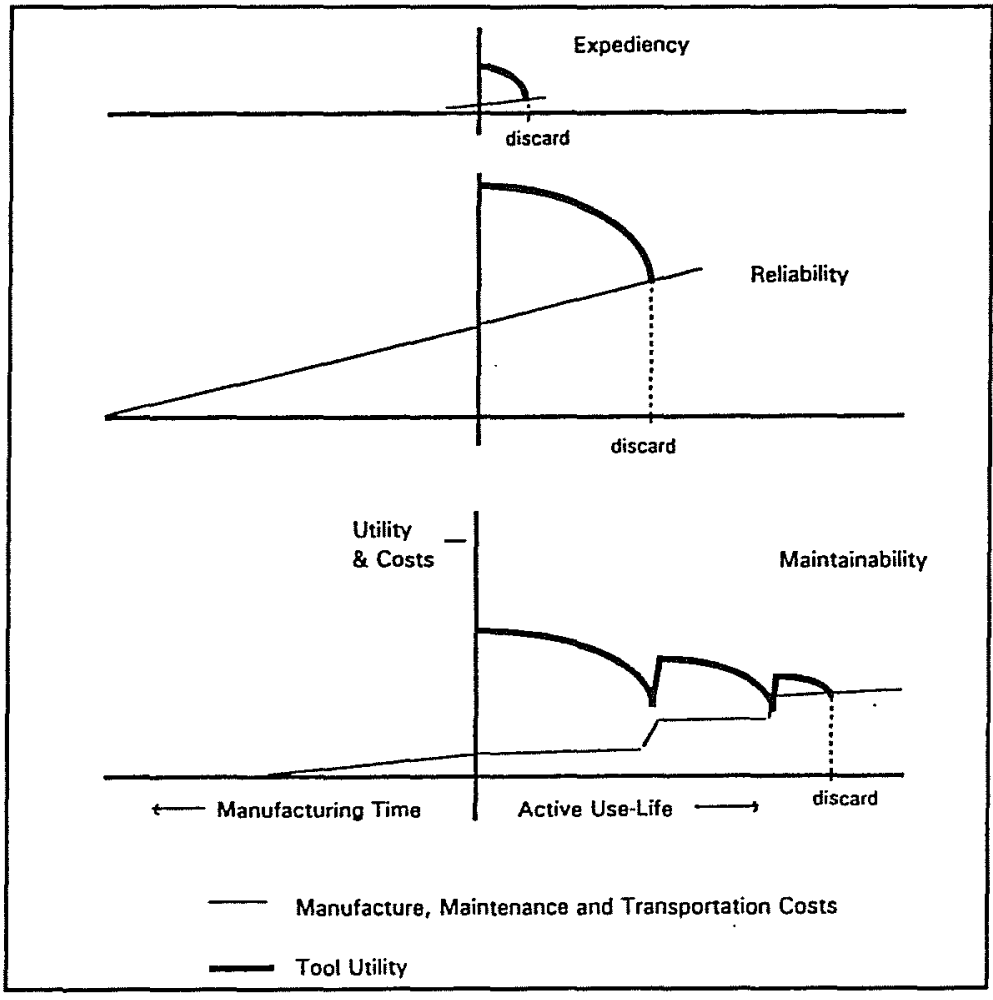

Figure 31. Tool utility/cost curves for different tool design goals.
The recovery of identifiable charred plant parts from in and around burned rock features provides the best direct indicator of plant species utilized for food and campfire fuel. These data have direct implications for the function of the burned rock features and season of use. While preservation of charred plant parts in south Texas is generally poor, we have recovered botanical samples from 41BX47, suggesting that potential for this type of study does exist in south-central Texas.

Faunal remains also are important in any analysis of past human exploitation habits. This includes species and skeletal element identification, analysis of relative dietary importance, meat butchering and transport, seasonality, and paleoenvironmental implications. 
Recent controlled experiments that varied screen mesh size ( $1 / 4$-inch, $1 / 8$-inch and $1 / 16$-inch window screen) demonstrates that $1 / 8$-inch screen results in a significant increase in the recovery of small animal bones without significantly increasing the excavation and sorting time (Shaffer 1992). The use of smaller mesh sizes results in a much more reliable picture of the subsistence practices of prehistoric societies.

\section{PAST CLIMATIC AND ENVIRONMENTAL CHANGES}

The second historic context concerns past climatic and environmental change. Potter et al. (1995) summarize recent studies of Late Pleistocene and Holocene climatic and environmental change in south Texas. At the height of the Late Pleistocene, some 18,000 years ago, ice sheets extended south into the United States, average annual temperatures were at least $5^{\circ} \mathrm{C}(9 \circ \mathrm{F})$ colder than present. The distribution of plants and animals was very different than those we see today, and a number of animals present in the Pleistocene are now extinct. At the end of the Pleistocene, about 10,000 years ago, large portions of the ice sheets had melted, temperatures dramatically increased, a number of animals became extinct, and the distribution of plants and animals began to reorganize along modern patterns.

The last 10,000 years, the period after the Pleistocene, is called the Holocene. Around 5000 years B.P. (before present) in the mid-Holocene, a pronounced dry and perhaps hot interval existed. Some researchers suggest this is a single period called the Altithermal, but the timing, severity, and regional climatic variability are debated. After the mid-Holocene dry interval, modern climatic and environmental patterns were established.

Ethnographic and ethnoarchaeological research indicates that fluctuating climatic regimes alter the flora and fauna exploited by hunters and gatherers for food and materials, and thus directly affect their lifeways (Binford 1980; Kelley 1983). Obtaining local data on changing past environments is critical for understanding the patterns recovered in the archaeological record. Potter et al. (1995) suggest that alluvial terraces with intact vertical stratigraphy are particularly informative property types (depositional contexts). Exploration and analysis of materials from alluvial terraces can contribute to this historic context. Issues related to alluvial sedimentation rates, changes in flora and fauna, landform alteration and its affect on site visibility, and the preservation of intact (often short-term) occupations by rapidly aggrading deposits can all be assessed and evaluated. Recovered charcoal can be used for radiocarbon dating and botanical analyses plus stable carbon isotope, snail, and phytolith analyses can be used to evaluate ecologically controlled shifts in plant and animal communities.

\section{RECOMMENDATIONS}

Site $41 \mathrm{BX} 47$ "is eligible for inclusion in the National Register of Historic Places under Criterion $\mathrm{D}$ because it has the potential to address important research issues relating to Late Paleoindian, Early Archaic, and Middle Archaic prehistory in Central Texas" (J. E. Bruseth and T. K. Perttula, Texas Historical Commission Officers, letter to W. Lea, Army Corps of Engineers, November 6, 1995). Without question the site offers important avenues for investigating the historic context concerned with prehistoric adaptations and subsistence. These should include plant and bone recovery, detailed examination of burned rock feature characteristics, life-history analysis of stone tools, and spatial organization of burned rock features and associated artifacts. Subtle shifts in adaptation will be discernible through such varied investigations.

Because of the umusual potential site $41 B \times 47$ has to provide information on the array of important questions discussed here, we urge this site be given full protection from any destructive activities until full investigation and data recovery can be performed. 


\section{REFERENCES CITED}

Barnes, V. E.

1983 Geologic Atlas of Texas: San Antonio Sheet. Bureau of Economic Geology, The University of Texas at Austin.

Bartram, L. E. , E. M. Knoll, and H. T. Bunn

1991 Variability in Camp Structure and Bone Food Refuse Patterning at Kua San Hunter-Gatherer Camps. In The Interpretation of Archaeological Spatial Patterning, edited by E. M. Kroll and T. D. Price, pp. 77-148. Plenum, New York.

Binford, L. R.

1973 Interassemblage Variability: the Mousterian and the Functional Argument'. In The Explanation of Cultural Change: Models in Prehistory, edited by C. Renfrew, pp. 227-254. Duckworth, London.

1980 Willow Smoke and Dogs' Tails: Hunter-Gatherer Settlement Systems and Archaeological Site Formation. American Antiquity 45: 4-20.

Birkeland, P. W.

1984 Soils and Geomorphology. Oxford University Press.

Black, S. L.

1989 Central Texas Plateau Prairie. In From the Gulf Coast to the Rio Grande: Human Adaptation in Central, South and Lower Pecos Texas, by T. R. Hester, S. L. Black, D. G. Steele, B. W. Olive, A. A. Fox, K. J. Reinhard, and L. C. Bement, pp. 17-38. Research Series No. 33. Arkansas Archeological Survey, Fayetteville.

Black, S. L., and A. J. McGraw

1985 The Panther Springs Creek Site: Cultural Change and Continuity in the Upper Salado Creek Drainage, South-Central Texas. Archaeological Survey Report, No. 100. Center for Archaeological Research, University of Texas at San Antonio.

Bleed, $\mathrm{P}$.

1986 The Optimal Design of Hunting Weapons: Maintainability or Reliability. American Antiquity 51: 737-747.

Blum, M. D., and S. Valastro, Jr.

1989 Response of the Pedernales River of Central Texas to Late Holocene Climatic Change. Annals of the Association of American Geographers, 79:435-456.

1994 Late Quaternary Sedimentation, Lower Colorado River, Gulf Coastal Plain of Texas. Geological Society of America Bulletin 106:1002-1016.

Bousman, C.B.

1991 Holocene Paleoecology and later Stone Age Hunter-Gatherer Adaptations in the South African Interior Plateau. Ph.D. dissertation, Southern Methodist University, Dallas.

1993 Hunter-Gatherer Adaptations, Economic Risk and Tool Design. Lithic Technology 18:59-86. 
Bousman, C. B., and M. B. Collins

1994 Summary of Investigations at the Wilson-Leonard Site. Paper presented at the symposium: Multidisciplinary Investigations at the Wilson-Leonard Site, Central Texas, 52nd Annual Plains Anthropological Conference, Lubbock, Texas.

Bousman, C. B., and S. A. Skinner

1983 Assemblage Composition and Occupation Span at Salt Gap, Texas. Manuscript on file with authors.

Boyd, D. K., J. Peck, S. A. Tomka, and K. W. Kibler

1993 Data Recovery at Justiceburg Reservoir (Lake Alan Henry), Garza and Kent Counties, Texas: Phase III, Season 2. Report of Investigations, Number 88, Prewitt and Associates, Austin.

Cheek, C. S., S. Bearden, W. Young, and C. B. Bousman

1980 Archeological Investigations at the Graham Site, 34AT90: 1975, 1977, and 1978. Research Report 23, Archeological Research Associates, Tulsa. Submitted to the U. S. Department of Interior, Heritage Conservation and Recreation Service, Mid-Continent Region, Interagency Archeological Service Division.

Collins, M. B.

1991 Thoughts on Future Investigation of Burned Rock Middens. In The Burned Rock Middens of Texas: an Archeological Symposium, edited by T. R. Hester, p. 1-24. Studies in Archeology 13. Texas Archeological Research Laboratory, The University of Texas at Austin.

Collins, M. B., C. B. Bousman, P. Goldberg, P. R. Takac, J. C. Guy, J. L. Lanata, T. W. Stafford, and V. T. Holliday

1993 The Paleoindian Sequence at the Wilson-Leonard Site, Texas. Current Research in the Pleistocene 10:10-12.

Collins, M. B., B. Ellis, and C. Dodt-Ellis

1990 Excavations at the Camp Pearl Wheat Site (41KR243): An Early Archaic campsite on Town Creek, Kerr County, Texas. Studies in Archeology 6. Texas Archeological Research Laboratory, The University of Texas at Austin.

Creel, D. G.

1986 Assessing the Importance of Acorns in Archaic Subsistence: The Distribution of Prehistoric Burned Rock Middens in West Central Texas. Unpublished Ph.D. dissertation, University of Arizona., Tucson.

Davis, D. R., Jr.

1991 Prehistoric Artifacts of the Texas Indians, an Identification and Reference Guide, Pecos Publishing, San Antonio.

Driver, H. E., and W. C. Massey

1957 Comparative Studies of North American Indians. Volume 47, Part 2, Transactions of the American Philosophical Society, Philadelphia. 
Ferring, C. R.

1986 Rates of Fluvial Sedimentation: Implications for Archaeological Variability. Geoarchaeology $1: 259-274$.

Gargett, R., and B. Hayden

1991 Site Structure, Kinship, and Sharing in Aboriginal Australia: Implications for Archaeology. In The Interpretation of Archaeological Spatial Patterning. Edited by E. M. Kroll and T. D. Price, pp. 11-32. Plenum Press, New York.

Goode, G. T.

1991 Late Prehistoric Burned Rock Middens in Central Texas. In The Burned Rock Middens of Texas: an Archeological Symposium, edited by Thomas R. Hester, pp. 71-93. Studies in Archeology 13, Texas Archeological Research Laboratory, The University of Texas at Austin.

Hester, T. R.

1978 Early Human Occupations in South Central and Southwestern Texas: Preliminary Papers on the Baker Cave and St. Mary's Hall Sites. Center for Archaeological Research, The University of Texas at San Antonio.

Hester, T. R. (editor)

1991 The Bumed Rock Middens of Texas: An Archeological Symposium. Studies in Archeology 13, Texas Archeological Research Laboratory, The University of Texas at Austin.

Hietala, H. (editor)

1984 Intrasite Spatial Analysis in Archaeology. Cambridge University Press, Cambridge.

Howard, M. A.

1991 Burned Rock Midden Excavations, Hearths and Botanical Remains. In The Burned Rock Middens of Texas: an Archeological Symposium, edited by Thomas R. Hester, pp. 45-69. Studies in Archeology 13, Texas Archeological Research Laboratory, The University of Texas at Austin.

Johnson, L., Jr.

1986 A Plague of Phases. Bulletin of the Texas Archeological Association 57:1-26.

1991 Early Archaic Life at the Sleeper Archaeological Site 41BC65 of the Texas Hill Country, Blanco County, Texas. Texas State Department of Highways and Public Transportation, Publications in Archaeology, Report No. 39. Austin.

Johnson, L., Jr., and G. T. Goode

1994 A New Try at Dating and Characterizing Holocene Climates, as well as Archeological Periods, on the Eastern Edwards Plateau. Bulletin of the Texas Archeological Association 65:1-51.

Keeley, L. H.

1991 Tool Use and Spatial Patterning: Complications and Solutions. In The Interpretation of Archaeological Spatial Patterning, edited by E. M. Kroll and T. D. Price, pp. 257-268. Plenum, New York. 
Kelley, R. L.

1983 Hunter-Gatherer Mobility Strategies. Journal of Anthropological Research 39: 277-306.

Kelley, J. C., and T. N. Campbell

1942 What Are the Burned Rock Mounds of Texas? American Antiquity 7:319-322.

Kenmotsu, N. A., and T. K. Perttula

1993 Archaeology in the Eastem Planning Region, Texas: A Planning Document. Cultural Resources Management Report 3. Department of Antiquities Protection, Texas Historical Commission, Austin.

Kroll, E. M., and T. D. Price (editors)

1991 The Interpretation of Archaeological Spatial Patterning. Plenum, New York.

McGraw, A. J., and K. Hindes

1987 Chipped Stone and Adobe: A Cultural Resources Assessment of the Proposed Applewhite Reservoir, Bexar County, Texas. Archeological Survey Report, No. 163, Center for Archeological Research, The University of Texas at San Antonio.

Miall, A. D.

1978 A Review of the Braided-River Depositional Environment. Earth-Science Reviews 13:1-62.

Nordt, L. C

1992 Archaeological Geology of the Fort Hood Military Reservation, Fort Hood, Texas. Research Report Number 25, United States Army Fort Hood, Archaeological Resource Management Series.

1995 Geoarchaeological Investigations of Henson Creek: A Low-Order Tributary in Central Texas. Geoarchaeology.

O'Connell, J. F.

1987 Alyawara Site Structure and its Archaeological Implications. American Antiquity 52:74-108.

O'Connell, J. F., K. Hawkes, and N. B. Jones

1991 Distribution of Refuse-Producing Activities at Hadza Residential Base Camps: Implications for Analyses of Archaeological Site Structure. In The Interpretation of Archaeological Spatial Patterning, edited by E. M. Kroll and T. D. Price, pp. 61-76. Plenum, New York.

Peter, D. E.

1982 Alternative Perspectives on Burned Rock Middens. Part v. In Final Draft Report, Archaeological Investigations at the San Gabriel Reservoir Districts, Central Texas, assembled by T. R. Hays, pp. 19.1-19.15. Manuscript on file, Department of Anthropology, Southern Methodist University, Dallas.

Potter, D. R., S. L. Black, and K. Jolly

1994 Archeology Along the Wurzbach Parkway: Module 1 Introduction, Conceptual Framework, and Contexts of Archeological Investigations in Bexar County, South-Central Texas. Studies in Archeology, No. 18, Texas Archeological Research Laboratory, The University of Texas at Austin. 
Potter, D. R., and S. L. Black

1995 Archeology along the Wurzbach Parkway, Module 2: Initial Testing and Evaluation of Five Prehistoric Sites in the Upper Salado Watershed, Bexar County, Texas. Studies in Archeology 18, Texas Archeological Research Laboratory, The University of Texas at Austin.

Prewitt, E. R.

1981 Cultural Chronology in Central Texas. Bulletin of the Texas Archeological Society 52:65-89.

1985 From Circleville to Toyah: Comments on Central Texas Chronology. Bulletin of the Texas Archeological Society 54:201-238.

Raba-Kistner Consultants, Inc.

1994 Geotechnical Engineering Study for Proposed Leon Creek Reservoir, San Antonio, Texas.

Ricklis, R. A., and R. R. Gunter

1986 Archaeological Investigations at the Means Site (41NU184), Nueces County, Texas. La Tierra $13: 15-32$.

Shaffer, B. S.

1992 Quarter-Inch Screening: Understanding Biases in Recovery of Vertebrate Faunal Remains. American Antiquity 57:129-136.

Soil Survey Division Staff

1993 Soil Survey Manual. U.S. Department of Agriculture-Soil Conservation Service, Agriculture Handbook 18. U.S. Government Printing Office, Washington, D.C.

Stevenson, M. G.

1991 Beyond the Formation of Hearth-Associated Artifact Assemblages. In The Interpretation of Archaeological Spatial Patterning, edited by E. M. Kroll and T. D. Price, p. 269-299. Plenum, New York.

Stothert, K.

1989 The Archaeology and Early History of the Headwaters of the San Antonio River. Southern Texas Archaeological Association Special Publication No. 5 and Incarnate Word Archaeology Series No. 3, San Antonio.

Taylor, F. B., R. B. Hailey, and D. L. Richmond

1991 Soil Survey of Bexar County. U.S. Department of Agriculture-Soil Conservation Service. U.S. Government Printing Office, Washington, D.C.

Tennis, C. L., and R. J. Hard

1995 Archaeological Survey of the Upper Leon Creek Terraces, Bexar County, Texas. Archaeological Survey Report, No. 233. Center for Archaeological Research, The University of Texas at San Antonio. 
Thoms, A. V.

1989 The Northern Roots of Hunter-Gatherer Intensification: Camas and the Pacific Northwest. Ph. D. dissertation, Department of Anthropology, Washington State University, Pullman.

1992 Late Pleistocene and Early Holocene Regional Land Use Patterns: A Perspective from the Preliminary Results of Archaeological Studies at the Richard Beene Site, 41BX831, Lower Medina River, South Texas. In Late Cenozoic Alluvial Stratigraphy and Prehistory of the Inner Gulf Plain, South-Central Texas. Lubbock Lake Quaternary Research Center Series No. 4, San Antonio.

Thoms, A. V., and R. D. Mandel.

1992 The Richard Beene Site: A Deeply Stratified Paleoindian to Late Prehistoric Occupation in South-Central Texas. Current Research in the Pleistocene 9:43-44.

Treece, A. C., C. Lintz, W. N. Trierweiler, J. M. Quigg, and K. A. Miller

1993 Cultural Resource Investigations in the O. H. Ivie Reservoir, Concho, Coleman, and Runnels Counties, Texas: Volume IV: Data Recovery from Ceramic Sites. Technical Report No. 346IV, Mariah Associates, Austin.

Turner, E. S., and T. R. Hester

1993 A Field Guide to Stone Artifacts of Texas Indians. Second Edition. Gulf Publishing, Houston.

Uecker, H. G.

1992 The UTSA Boulevard Project: Archaeological Survey Along Leon Creek in Northwest San Antonio, Texas. Archaeological Survey Report, No. 216, Center for Archaeological Research, The University of Texas at San Antonio.

Weir, F.

1976 The Central Texas Archaic. Ph. D. dissertation, Department of Anthropology, Washington State University, Pullman.

Whitelaw, T.

1991 Some Dimensions of Variability in the Social Organization of Community Space among Foragers. In Ethnoarchaeological approaches to Mobile Campsites: Hunter-Gatherer and Pastoralist Case Studies, edited by C. S. Gamble and W. A. Boismier, pp. 139-188. International Monographs in Prehistory, Ann Arbor, Michigan.

Yellen, J. E.

1977 Archaeological Approaches to the Present: Models for Reconstructing the Past. Academic Press, New York. 


\title{
APPENDIX A: SOIL-STRATIGRAPHIC DESCRIPTIONS
}

\author{
Lee C. Nordt
}

\section{TERRACE 4}

BHT-16 - calcareous throughout.

Ap $\quad$ 0-19 cm; Unit I-f; very dark brown (10YR 2.5/2) silty clay loam; moderate medium angular blocky; very hard; common sand-size $\mathrm{CaCO}_{3}$ grains; gradual smooth.

Bk1 19-41 cm; Unit I-f; brown (10YR 4/3) silty clay loam with $5 \%$ yellowish brown (10YR 5/4); moderate coarse angular blocky; very hard; $2 \%$ filaments of $\mathrm{CaCO}_{3}$; clear smooth.

$\mathrm{Bk} 2 \quad 41-72 \mathrm{~cm}$; Unit I-f; brown (7.5YR 5/4) silty clay loam; weak coarse prismatic; slightly hard; 3-4\% filaments of $\mathrm{CaCO}_{3} ; 10 \%$ hard and pitted nodules of $\mathrm{CaCO}_{3} \quad 0.3-1 \mathrm{~cm}$ diameter; clear smooth.

Bk3 72-123 cm; Unit I-f; strong brown (7.5YR 5/6) silty clay loam; weak coarse prismatic; slightly hard; $20 \%$ hard and pitted nodules of $\mathrm{CaCO}_{3} \quad 0.3-1 \mathrm{~cm}$ diameter; gradual smooth.

Bk4 123-153 cm; Unit I-f; strong brown (7.5YR 5.5/6) clay loam; weak coarse prismatic; slightly hard; $2 \%$ hard and pitted nodules of $\mathrm{CaCO}_{3} \quad 0.3-1 \mathrm{~cm}$ diameter; gradual smooth.

Bk5 153-200 cm; Unit I-f; reddish yellowish (7.5YR 6/6) sandy clay loam; weak coarse prismatic; hard; $3 \%$ filaments of $\mathrm{CaCO}_{3} ; 2 \%$ hard and pitted nodules of $\mathrm{CaCO}_{3} 2 \mathrm{~cm}$ diameter; gradual smooth.

BC 200-243 cm; Unit I-c; reddish yellow (7.5YR 7/6) sandy clay loam; weak coarse prismatic; hard; $1 \%$ hard and pitted nodules of $\mathrm{CaCO}_{3} 2 \mathrm{~cm}$ diameter; gradual smooth.

C 243-293 cm; Unit I-c; reddish yellow (7.5YR 7/6) sandy clay loam; massive; hard.

BHT-22 - Calcareous throughout.

Ap 0-24 cm; Unit II-f; very dark grayish brown (10YR 3/2.5) clay loam; moderate coarse angular blocky; firm; many sand-size $\mathrm{CaCO}_{3}$ grains; gradual smooth.

BA 24-44 cm; Unit II-f; dark brown (10YR 3/3) clay loam; weak coarse angular blocky; firm; many sand-size $\mathrm{CaCO}_{3}$ grains; clear smooth.

Bk1 $\quad 44-65 \mathrm{~cm}$; Unit II-f; dark yellowish brown (10YR 3.5/4) clay loam; weak coarse prismatic; very firm; $1-2 \%$ filaments of $\mathrm{CaCO}_{3}$; few coarse fragments; clear smooth.

Bk2 65-98 cm; Unit II-f; dark yellowish brown (10YR 4/4) clay loam; weak coarse prismatic; firm; $1 \%$ filaments of $\mathrm{CaCO}_{3} ; 5 \%$ coarse fragments $0.2-1 \mathrm{~cm}$ diameter; clear smooth.

2Bk3b 98-152 cm; Unit I-f; reddish yellow (7.5YR 6/6) silty clay loam; weak coarse prismatic; very firm; $5-8 \%$ brittle nodules of $\mathrm{CaCO}_{3} 0.5 \mathrm{~cm}$ diameter; few fine coarse fragments; gradual smooth.

2Bk4b 152-210 cm; Unit I-c; reddish yellow (7.5YR 6/6) sandy loam; weak coarse prismatic; friable; $2 \%$ brittle nodules of $\mathrm{CaCO}_{3} 0.5-1.5 \mathrm{~cm}$ diameter; few fine coarse fragments; abrupt smooth.

$2 \mathrm{Cb} \quad 210-298 \mathrm{~cm}$; Unit I-c; upper $25 \mathrm{~cm}$ contains horizontally bedded, moderately well sorted and grain supported coarse fragments $0.5-2.5 \mathrm{~cm}$ diameter; below is reddish yellow (7.5YR 6/8) loamy sand with occasional thin $\mathrm{CaCO}_{3}$-cemented gravel beds. 
BHT-25 - calcareous throughout.

Ap $\quad 0-22 \mathrm{~cm}$; Unit II-f; black (10YR 2/1) clay loam; moderate medium angular blocky; firm; abrupt smooth.

Bw 22-42 cm; Unit II-f; dark brown (7.5YR 3.5/3) clay loam; weak coarse angular blocky; firm; gradual smooth.

Bk $\quad 42-88 \mathrm{~cm}$; Unit II-f; brown (7.5YR 4/4) clay loam; weak coarse angular blocky; firm; $2 \%$ filaments of $\mathrm{CaCO}_{3} ; 3-4 \%$ coarse fragments $1 \mathrm{~cm}$ diameter; thin gravel line at contact; abrupt smooth.

$\mathrm{Ab} \quad 88-131 \mathrm{~cm}$; Unit II-f; brown (7.5YR 4/3) clay; moderate medium prismatic; very hard; $1 \%$ nodules of $\mathrm{CaCO}_{3} 0.5 \mathrm{~cm}$ diameter; gradual smooth (C-14 age of $5810 \pm 50$ B.P. at $105-117 \mathrm{~cm}$, Beta-81546).

Bsskb 131-180 cm; Unit II-f; brown (7.5YR 5/3) clay; moderate medium angular blocky; very hard; $1 \%$ nodules of $\mathrm{CaCO}_{3} 0.5 \mathrm{~cm}$ diameter; few faint slickensides.

H2U2 - calcareous throughout.

\section{TERRACE 3}

C/A 0-9 cm; Unit V-c?; $2 \mathrm{~cm}$ thick bedding planes of brownish yellow (10YR 6/6) and dark brown (10YR 3/3) sandy clay loam; $2 \%$ coarse fragments $0.2-0.4 \mathrm{~cm}$ diameter; abrupt smooth.

2Ab1 9-27 cm; Units III-f; very dark grayish brown (10YR 3/2.5) sandy clay loam; weak coarse angular blocky; hard; same coarse fragments as above, but with few $0.5-1 \mathrm{~cm}$; gradual smooth.

2Bwb1 27-41 cm; Units III-f; dark brown (10YR 3/3) sandy clay loam; weak coarse angular blocky; hard; many very dark grayish brown (10YR 3/2) and yellowish brown (10YR 5/6) biocasts; abrupt smooth.

3Ab2 41-73 cm; Unit II-f; very dark brown (10YR 2.5/2) sandy clay loam; moderate coarse subangular blocky; firm; common yellowish brown (10YR 5/6) biocasts; $3 \%$ coarse fragments $0.5-3 \mathrm{~cm}$ diameter; clear smooth.

3Akb2 73-100 cm; Unit II-f; very dark grayish brown (10YR 3/2) sandy clay loam; moderate medium subangular blocky; hard; $2 \%$ filaments of $\mathrm{CaCO}_{3} ; 3 \%$ coarse fragments $0.5-3 \mathrm{~cm}$ diameter; clear smooth.

3Bk1b2 100-127 cm; Unit II-f; brown (10YR 4/3) clay loam; moderate medium subangular blocky; hard; common yellowish brown (10YR 5/6) biocasts; $4 \%$ filaments of $\mathrm{CaCO}_{3} ; 10-12 \%$ coarse fragments 1-3 cm diameter; clear smooth; (Gower point at $110 \mathrm{~cm}$ ).

3Bk2b2 127-139 cm; Unit II-f; dark yellowish brown (10YR 4.5/4) clay loam; weak coarse angular blocky; hard; common yellowish brown (10YR 5/6) biocasts; $5 \%$ filaments of $\mathrm{CaCO}_{3}$; 10 $12 \%$ coarse fragments $1-3 \mathrm{~cm}$ diameter; gradual smooth; (Angostura point at $125 \mathrm{~cm}$ ).

3Bk3b2 139-169 cm; Unit III-f; brown (7.5YR 5/4) clay loam; weak coarse prismatic; firm; 4\% filaments of $\mathrm{CaCO}_{3} ; 4-5 \%$ coarse fragments $0.5-1 \mathrm{~cm}$ diameter; gradual smooth.

3C1b2 169-200 cm; Unit II-f; brown (7.5YR 5/4) clay loam; massive; $1-2 \%$ coarse fragments $0.5-1 \mathrm{~cm}$ diameter; gradual smooth.

3C2b2 200-224 cm; Unit II-f; brown (7.5YR 5/4) sandy clay loam; massive; $20 \%$ dark brown (7.5YR 4/4) biocasts; $1 \%$ coarse fragments $0.5-1 \mathrm{~cm}$ diameter; gradual smooth.

3C3b2 224-272 cm; Unit II-c; reddish yellow (7.5YR 6/6) sand; massive; $20 \%$ dark brown (7.5YR 4/4) biocasts. 
BHT-13 - calcareous throughout.

Ap $\quad$ 0-14 cm; Unit II-f; dark brown (10YR 3/3) clay loam; weak coarse angular blocky; very firm; 2-3\% coarse fragments $1 \mathrm{~cm}$ diameter; many sand-size $\mathrm{CaCO}_{3}$ grains; clear smooth.

A $\quad 14-30 \mathrm{~cm}$; Unit II-f; very dark brown (10YR 2/2) clay loam; moderate medium subangular blocky; hard; $3-4 \%$ coarse fragments $0.5-1 \mathrm{~cm}$ diameter; common sand-size $\mathrm{CaCO}_{3}$ grains; gradual smooth.

Bk1 30-62 cm; Unit II-f; dark yellowish brown (10YR 4/4) clay loam; moderate medium angular blocky; firm; $4-5 \%$ filaments of $\mathrm{CaCO}_{3} ; 5-7 \%$ coarse fragments $0.5-1.5 \mathrm{~cm}$ diameter; gradual smooth.

Bk2 62-120 cm; Unit II-f; strong brown (7.5YR 5/6) clay loam; weak medium angular blocky; firm; 7-8\% filaments of $\mathrm{CaCO}_{3} ; 3-4 \%$ coarse fragments $0.5-1.5 \mathrm{~cm}$ diameter; clear smooth.

Bk3 120-160 cm; Unit II-f; strong brown (7.5YR 4/6) silty clay loam; weak medium prismatic; very firm; 7-8\% filaments of $\mathrm{CaCO}_{3} ; 3-4 \%$ coarse fragments $0.5-1.5 \mathrm{~cm}$ diameter; clear smooth.

BC 160-184 cm; Unit II-f; strong brown (7.5YR 4/6) clay loam; weak coarse prismatic; very hard; $1 \%$ filaments of $\mathrm{CaCO}_{3} ; 3-4 \%$ coarse fragments $0.5-1.5 \mathrm{~cm}$ diameter; abrupt wavy. C $\quad 184-212 \mathrm{~cm}$; Unit II-c; brown (7.5YR 4/4) sandy clay loam; massive; $70 \%$ coarse fragments, subrounded, moderately well sorted and $0.5-5 \mathrm{~cm}$ diameter.

FG2 - calcareous throughout.

Ap $\quad$ 0-10 cm; Unit II-f; very dark gray (10YR 3/1) sandy clay loam; moderate coarse angular blocky; very hard; $2 \%$ coarse fragments $0.5-1 \mathrm{~cm}$ diameter; many sand-size $\mathrm{CaCO}_{3}$ grains; clear smooth.

A $\quad 10-41 \mathrm{~cm}$; Unit II-f; black (10YR 2/1) sandy clay loam; moderate coarse angular blocky; very firm; $1 \%$ coarse fragments $0.5-1 \mathrm{~cm}$ diameter; many sand-size $\mathrm{CaCO}_{3}$ grains; gradual smooth.

Bw 41-63 cm; Unit II-f; very dark grayish brown (10YR 3/2) sandy clay loam; moderate coarse prismatic; very hard; $10 \%$ coarse fragments $0.2-0.4 \mathrm{~cm}$ diameter and $2 \% 0.5-1 \mathrm{~cm}$ diameter; gradual smooth.

Bk1 63-94 cm; Unit II-f; brown (10YR 4/3) sandy clay loam; moderate coarse prismatic; very hard; 6-7\% filaments of $\mathrm{CaCO}_{3} ; 10 \%$ coarse fragments $0.2-0.4 \mathrm{~cm}$ diameter and $2 \% 0.5$ $1 \mathrm{~cm}$ diameter; gradual smooth.

Bk2 94-156 cm; Unit II-f; strong brown (7.5YR 5/6) sandy clay loam; moderate coarse prismatic; hard; $5 \%$ filaments of $\mathrm{CaCO}_{3} ; 10 \%$ coarse fragments $0.2-0.4 \mathrm{~cm}$ diameter and $2 \% 0.5-1 \mathrm{~cm}$ diameter; gradual smooth.

Bk3 156-226 cm; Unit II-f; strong brown (7.5YR 5/6) sandy clay loam; moderate coarse prismatic; hard; $3-4 \%$ filaments of $\mathrm{CaCO}_{3} ; 10 \%$ coarse fragments $0.2-0.4 \mathrm{~cm}$ diameter, $2 \% 0.5-1 \mathrm{~cm}$ diameter, and $5-8 \% 1-3 \mathrm{~cm}$ diameter; abrupt wavy.

Bk4 226-253 cm; Unit II-f; brown (7.5YR 5/4) and yellowish red (5YR 5/6) sandy clay loam; weak coarse prismatic; firm; $1-2 \%$ filaments of $\mathrm{CaCO}_{3} ; 5 \%$ coarse fragments $0.5-1 \mathrm{~cm}$ diameter; gradual smooth.

BCk 253-269 cm; Unit II-f; strong brown (7.5YR 5/6) and 20\% brown (7.5YR 5/4) sandy clay loam; weak coarse prismatic; firm; $1 \%$ filaments of $\mathrm{CaCO}_{3} ; 5 \%$ coarse fragments $0.5-1$ $\mathrm{cm}$ diameter; bulk humate $\mathrm{C}-14$ age of $7440 \pm 100$ at $253-265 \mathrm{~cm}$, Beta-81547). 
BHT-12 - calcareous throughout.

A $\quad 0-23 \mathrm{~cm}$; Unit III-f; black (10YR 2/1.5) clay loam; moderate coarse angular blocky; very hard; $2 \%$ coarse fragments $1 \mathrm{~cm}$ diameter; common sand-size $\mathrm{CaCO}_{3}$ grains; gradual smooth.

2Bk1b 23-43 cm; Unit II-f; dark brown (10YR 3/3) sandy clay loam; moderate medium prismatic; very hard; $4-5 \%$ filaments of $\mathrm{CaCO}_{3} ; 5 \%$ coarse fragments $1-2 \mathrm{~cm}$ diameter; gradual smooth.

2Bk2b 43-62 cm; Unit II-f; dark yellowish brown (10YR 4/4) sandy clay loam; Moderate coarse prismatic; hard; $45 \%$ filaments of $\mathrm{CaCO}_{3} ; 5 \%$ coarse fragments $1-2 \mathrm{~cm}$ diameter; gradual smooth.

2Bk3b 62-78 cm; Unit II-f; yellowish brown (10YR 5/4) sandy clay loam; weak coarse prismatic; hard; $3 \%$ filaments of $\mathrm{CaCO}_{3} ; 7-8 \%$ coarse fragments $0.5-2 \mathrm{~cm}$ diameter; clear smooth.

2Bk4b 78-93 cm; Unit II-c; brown (7.5YR 5/4) sandy clay loam; weak medium prismatic; hard; $2 \%$ filaments of $\mathrm{CaCO}_{3} ; 20 \%$ coarse fragments $0.5-2 \mathrm{~cm}$ diameter; abrupt wavy.

$2 \mathrm{Cb} \quad 93-170 \mathrm{~cm}$; Unit II-c; strong brown (7.5YR 5/6) sandy loam; $70 \%$ coarse fragments, moderately well sorted, subrounded, imbricated and $0.5-2 \mathrm{~cm}$ diameter in upper part and $7-8 \mathrm{~cm}$ diameter in lower part.

BHT-B - calcareous throughout.

A $\quad 0-28 \mathrm{~cm}$; Unit II-f; very dark grayish brown (10YR 3/2) sandy clay loam; moderate medium subangular blocky; firm; $3-4 \%$ coarse fragments $0.5-1 \mathrm{~cm}$ diameter; many sandsize $\mathrm{CaCO}_{3}$ grains; gradual smooth.

Bk1 28-62 cm; Unit II-f; dark yellowish brown (10YR 4/4) sandy clay loam; moderate medium prismatic; friable; $1 \%$ filaments of $\mathrm{CaCO}_{3} ; 5-6 \%$ coarse fragments $0.5-1 \mathrm{~cm}$ diameter; clear wavy.

Bk2 $62-89 \mathrm{~cm}$; Unit II-c; yellowish brown (10YR 4/4); sandy clay loam; massive; $20 \%$ patchy $\mathrm{CaCO}_{3}$ pebble pendants $1 \mathrm{~mm}$ thick; $25-30 \%$ coarse fragments $1-8 \mathrm{~cm}$ diameter; abrupt wavy.

$\mathrm{Ck} \quad 89-123 \mathrm{~cm}$; Unit II-c; yellowish brown (10YR 5/4); $70 \%$ coarse fragments, grain supported, moderately well sorted and $0.2-8 \mathrm{~cm}$ diameter; $20 \%$ patchy $\mathrm{CaCO}_{3}$ pebble pendants $1 \mathrm{~mm}$ thick.

BHT-A - calcareous throughout.

\section{TERRACE 1}

A/C $\quad 0-7 \mathrm{~cm}$; Unit V-f?; very dark gray (10YR 3/1) clay loam; moderate fine subangular blocky; hard; $3 \%$ coarse fragments $1 \mathrm{~cm}$ diameter; many sand size $\mathrm{CaCO}_{3}$ grains; clear smooth.

$2 \mathrm{Ab} \quad 7-44 \mathrm{~cm}$; Unit IV-f; black (10YR 2/1) clay loam; moderate fine and medium subangular blocky; hard; gradual smooth.

2Bw1b $\quad 44-81 \mathrm{~cm}$; Unit IV-f; very dark grayish brown (10YR 3/2) sandy clay loam; weak coarse prismatic; firm; gradual smooth.

2Bw2b 81-115 cm; Unit IV-f; brown (10YR 4/3) sandy clay loam; weak coarse prismatic; firm; clear smooth.

2Bkb 115-174 cm; Unit IV-f; brown (10YR 3.5/3) sandy clay loam; weak coarse prismatic; firm; $1 \%$ filaments of $\mathrm{CaCO}_{3}$; abrupt wavy.

$2 \mathrm{Cb} \quad 174-193 \mathrm{~cm}$; Unit IV-c; $60 \%$ coarse fragments $0.2-3 \mathrm{~cm}$ diameter over dark grayish brown (10YR 4/2) sandy clay loam over grain supported and moderately well sorted $1-5 \mathrm{~cm}$ diameter coarse fragments dipping slightly towards modern channel. 


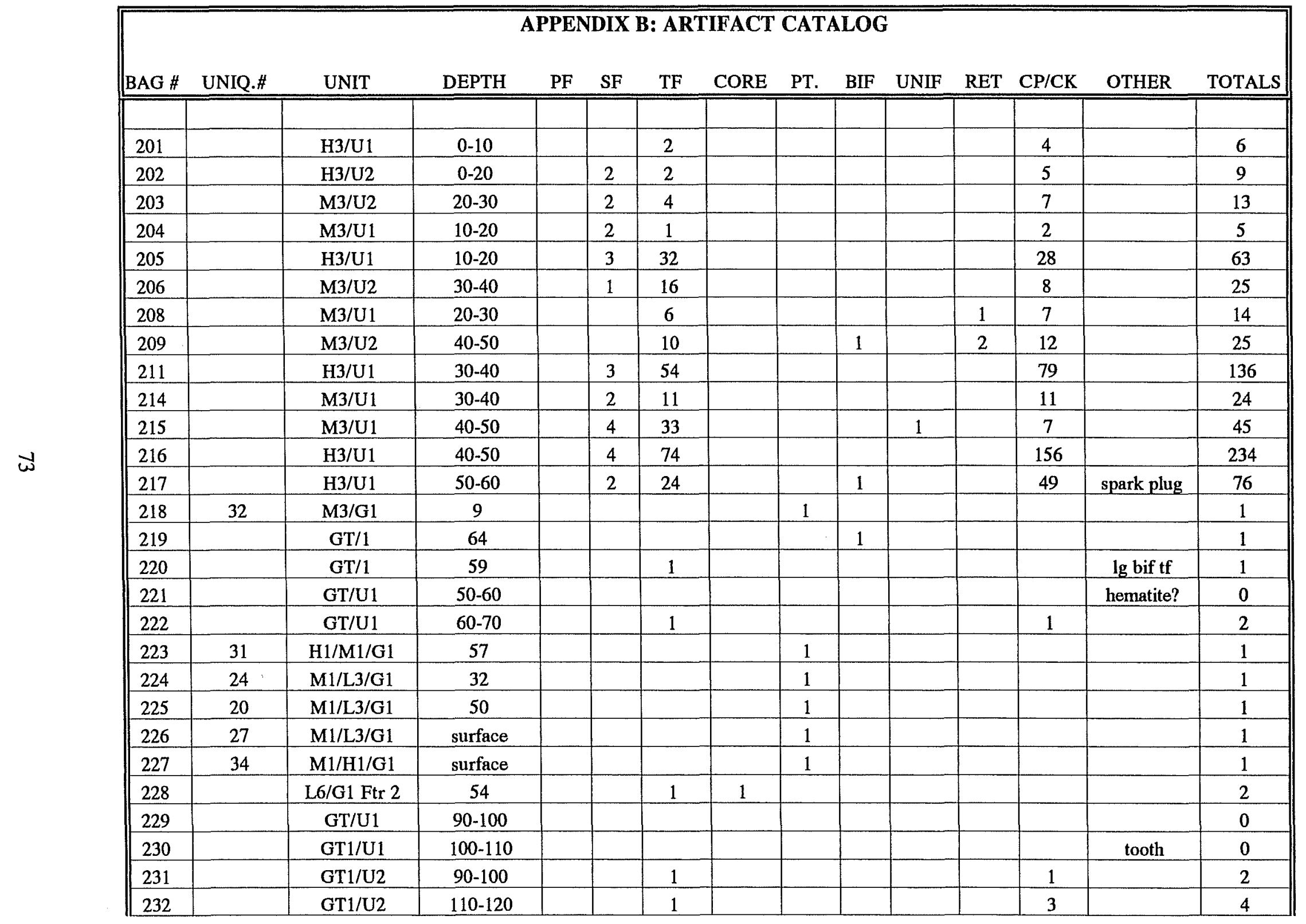




\begin{tabular}{|c|c|c|c|c|c|c|c|c|c|c|c|c|c|c|}
\hline \multirow[b]{2}{*}{$\mathrm{BAG} \#$} & \multirow[b]{2}{*}{ UNIQ.\# } & \multirow[b]{2}{*}{ UNIT } & \multirow[b]{2}{*}{ DEPTH } & \multicolumn{5}{|c|}{ APPENDIX B: continued } & \multirow[b]{2}{*}{$\mathrm{BIF}$} & \multirow[b]{2}{*}{ UNIF } & \multirow[b]{2}{*}{ RET } & \multirow[b]{2}{*}{$\mathrm{CP} / \mathrm{CK}$} & \multirow[b]{2}{*}{ OTHER } & \multirow[b]{2}{*}{ TOTALS } \\
\hline & & & & PF & SF & TF & CORE & PT. & & & & & & \\
\hline 233 & & GT1/U1 & $70-80$ & & & 1 & & & & & & & & 1 \\
\hline 234 & 28 & $\mathrm{H} 2 / \mathrm{G} 2$ & 10 & & & & & 1 & & & & & & 1 \\
\hline 235 & & $\mathrm{M} 2 / \mathrm{G} 1$ & 4 & & & & & & 1 & & & & & 1 \\
\hline 236 & 29 & $\mathrm{M} 2 / \mathrm{G} 2$ & $12-16$ & & & 4 & & 1 & & & 1 & 1 & & 7 \\
\hline 237 & $21,22,23$ & $\mathrm{M} 2 / \mathrm{G} 2$ & $24-28$ & & 9 & 20 & & 3 & 2 & & 1 & 9 & & 44 \\
\hline 238 & 25,26 & $\mathrm{H} 2 / \mathrm{G} 2$ & $10-20$ & & & 4 & & 2 & 1 & & 1 & 1 & & 9 \\
\hline 239 & 35 & $\mathrm{H} 2 / \mathrm{U} 1$ & 9.5 & & & & & 1 & & & & & & 1 \\
\hline 240 & & $\mathrm{H} 2 / \mathrm{U} 1$ & 20 & & & & & & 1 & & & & & 1 \\
\hline 242 & 30 & $\mathrm{H} 2 / \mathrm{U} 1$ & 32 & & & & & 1 & & & & & & 1 \\
\hline 243 & & $\mathrm{M} 1 / \mathrm{U} 1$ & 10 & & & & & & 1 & & 2 & 16 & & 19 \\
\hline 244 & & $\mathrm{M} 1 / \mathrm{U} 1$ & $20-30$ & & 1 & 8 & & & & & & 12 & & 21 \\
\hline 246 & & M1/U1 & $40-50$ & & 1 & 19 & & & & & 2 & 7 & charcoal & 29 \\
\hline 247 & & GT1/U2 & $65-70$ & & & & & & & & & 2 & & 2 \\
\hline 248 & & $\mathrm{H} 2 / \mathrm{G} 4$ & 24-28 & & & $\cdot$ & & & 1 & & & & & 1 \\
\hline 249 & 33 & $\mathrm{H} 2 / \mathrm{G} 3$ & 20 & & & & & 1 & & & & & & 1 \\
\hline 250 & & $\mathrm{~L} 6 / \mathrm{G} 2$ & 16 & & & & & & & & & & charcoal & 0 \\
\hline 251 & 37 & $\mathrm{H} 2 / \mathrm{G} 3$ & $30-35$ & & & & & 1 & & & & & & 1 \\
\hline 252 & & $\mathrm{H} 1 / \mathrm{U} 1$ & $0-10$ & & 1 & 18 & & & & & & 20 & & 39 \\
\hline 253 & & $\mathrm{H} 1 / \mathrm{U} 1$ & $10-20$ & & 3 & 18 & & & & & 1 & 25 & & 47 \\
\hline 254 & & $\mathrm{H} 1 / \mathrm{U} 1$ & $20-30$ & & & 29 & & & & & & 26 & & 55 \\
\hline 255 & & $\mathrm{H} 1 / \mathrm{U} 1$ & $30-40$ & & & 4 & & & & & & 12 & & 16 \\
\hline 256 & & $\mathrm{H} 2 / \mathrm{U} 1$ & $0-10$ & 1 & 2 & 26 & & & & & 1 & 30 & & 60 \\
\hline 257 & & $\mathrm{H} 2 / \mathrm{U} 1$ & $10-20$ & & 5 & 51 & & & & & & 41 & & 97 \\
\hline 258 & & $\mathrm{H} 2 / \mathrm{U} 1$ & $20-30$ & & 3 & 22 & & & 2 & & 2 & 39 & & 68 \\
\hline 260 & & $\mathrm{H} 2 / \mathrm{U} 1$ & $50-60$ & & 1 & 31 & & & 1 & 1 & & 38 & & 72 \\
\hline 261 & & $\mathrm{H} 2 / \mathrm{U} 1$ & $60-70$ & & 4 & 32 & 2 & & 1 & & & 28 & & 67 \\
\hline 262 & & $\mathrm{H} 2 / \mathrm{U} 1$ & $70-80$ & & 1 & 17 & & & & & & 11 & & 29 \\
\hline
\end{tabular}




\begin{tabular}{|c|c|c|c|c|c|c|c|c|c|c|c|c|c|c|}
\hline \multicolumn{15}{|c|}{ APPENDIX B: continued } \\
\hline BAG \# & UNIQ.\# & UNIT & DEPTH & $\mathrm{PF}$ & SF & $\mathrm{TF}$ & CORE & PT. & $\mathrm{BIF}$ & UNIF & RET & $\mathrm{CP} / \mathrm{CK}$ & OTHER & TOTALS \\
\hline 263 & 41 & $\mathrm{M} 2 / \mathrm{U} 1$ & $0-10$ & & 5 & 46 & 1 & 1 & 1 & & & 89 & & 143 \\
\hline 264 & & $\mathrm{M} 2 / \mathrm{U} 1$ & $10-20$ & & 4 & 74 & & & & & 3 & 74 & & 155 \\
\hline 265 & & $\mathrm{M} 2 / \mathrm{U} 1$ & $20-30$ & & 11 & 50 & & & 1 & & & 73 & & 135 \\
\hline 266 & & $\mathrm{M} 2 / \mathrm{U} 1$ & $30-40$ & & 1 & 62 & & & 1 & & 1 & 49 & & 114 \\
\hline 267 & & $\mathrm{M} 2 / \mathrm{U} 1$ & $40-50$ & & 2 & 40 & & & & & 5 & 29 & & 76 \\
\hline 268 & & FG1 & $60-63$ & & & & & & 1 & & & & & 1 \\
\hline 269 & & FG1 & $0-50$ & & & & & & 1 & & & & & 1 \\
\hline 270 & & $\mathrm{~L} 1 / \mathrm{G} 1$ & $40-44$ & & & & & & 1 & & & & & 1 \\
\hline 271 & & GT2/U2 & $0-80$ & & & & & & & & & & & 0 \\
\hline 272 & & $\mathrm{M} 1 / \mathrm{U} 1$ & $50-60$ & & 1 & 13 & & & & & & 1 & charcoal & 15 \\
\hline 273 & & GT2/U2 & $80-90$ & & & 1 & & & & & & & & 1 \\
\hline 274 & & GT2/U2 & $90-100$ & & & & & & & & & & & 0 \\
\hline 275 & & GT2/U1 & $70-80$ & & & 1 & & & & & & & & 1 \\
\hline 276 & & GT2/U1 & $80-90$ & & & 2 & & & & & & 1 & & 3 \\
\hline 277 & & $\mathrm{H} 2 / \mathrm{U} 1$ & $30-40$ & 1 & 10 & 32 & & & & & & 18 & & 61 \\
\hline 278 & & $\mathrm{H} 2 / \mathrm{U} 2$ & 0.10 & & & 4 & & & & & & 2 & & 6 \\
\hline 279 & & $\mathrm{H} 2 / \mathrm{U} 2$ & $10-20$ & & & 1 & & & & & & 2 & & 3 \\
\hline 280 & & $\mathrm{H} 2 / \mathrm{U} 2$ & $20-30$ & & 2 & 6 & & & & & & 8 & & 16 \\
\hline 281 & & $\mathrm{H} 2 / \mathrm{U} 2$ & $30-40$ & & 2 & 2 & & & & & 1 & 5 & & 10 \\
\hline 282 & & $\mathrm{H} 2 / \mathrm{U} 2$ & $40-50$ & & 1 & 3 & & & & & & 3 & & 7 \\
\hline 283 & & $\mathrm{H} 2 / \mathrm{U} 2$ & $50-60$ & & 2 & 9 & & & 2 & & 1 & 4 & & 18 \\
\hline 284 & & $\mathrm{H} 2 / \mathrm{U} 2$ & $60-70$ & & 4 & 11 & & & 1 & & 1 & 13 & & 30 \\
\hline 285 & & $\mathrm{H} 2 / \mathrm{U} 2$ & $70-80$ & & 2 & 14 & & & & & 3 & 19 & & 38 \\
\hline 286 & & $\mathrm{H} 2 / \mathrm{U} 2$ & $80-90$ & & 3 & 18 & & & & & & 11 & & 32 \\
\hline 287 & & $\mathrm{H} 2 / \mathrm{U} 2$ & $90-100$ & & 2 & 22 & & & & & 3 & 13 & & 40 \\
\hline 288 & & $\mathrm{H} 2 / \mathrm{U} 3$ & $0-10$ & & 11 & 41 & & & & & 1 & 55 & & 108 \\
\hline 289 & & $\mathrm{H} 2 / \mathrm{U} 3$ & $10-20$ & & 3 & 35 & & & & & & 50 & & 88 \\
\hline 290 & & $\mathrm{H} 2 / \mathrm{U} 4$ & $0-10$ & & 9 & 80 & & & & & 3 & 145 & & 237 \\
\hline 291 & 40 & $\mathrm{H} 2 / \mathrm{U} 4$ & $10-20$ & & 97 & 9 & 1 & 1 & 2 & & 6 & 121 & & 237 \\
\hline
\end{tabular}




\begin{tabular}{|c|c|c|c|c|c|c|c|c|c|c|c|c|c|c|}
\hline \multirow[b]{2}{*}{$\mathrm{BAG} \#$} & \multicolumn{14}{|c|}{ APPENDIX B: continued } \\
\hline & UNIQ.\# & UNIT & DEPTH & PF & SF & TF & CORE & PT. & BIF & UNIF & RET & $\mathrm{CP} / \mathrm{CK}$ & OTHER & TOTALS \\
\hline 292 & & $\mathrm{H} 2 / \mathrm{U} 4$ & $20-30$ & 1 & 8 & 49 & & & 2 & & 2 & 80 & & 142 \\
\hline 293 & & $\mathrm{H} 2 / \mathrm{U} 4$ & $30-40$ & & 6 & 43 & & & 1 & & & 61 & & 111 \\
\hline 294 & & $\mathrm{H} 2 / \mathrm{U} 4$ & $40-50$ & & 3 & 28 & & & & & 4 & 30 & & 65 \\
\hline 295 & & $\mathrm{H} 2 / \mathrm{U} 4$ & $50-60$ & & & 10 & & & & & & 9 & & 19 \\
\hline 296 & & $\mathrm{H} 2 / \mathrm{U} 4$ & $60-70$ & & 1 & 2 & & & & & & 5 & & 8 \\
\hline 297 & & $\mathrm{~L} 6 / \mathrm{G} 4$ & 28 & & & & & & 1 & & & & & 1 \\
\hline 298 & & L6/G4 & 28 & & & & & & 1 & & & & & 1 \\
\hline 299 & & L4/G1 & $95-100$ & & & & & & 1 & & & & & 1 \\
\hline 300 & & $\mathrm{H} 2 / \mathrm{U} 3$ & $20-30$ & & 2 & 6 & & & 2 & & 2 & 18 & & 30 \\
\hline 301 & 36 & $\mathrm{H} 2 / \mathrm{U} 2$ & $100-110$ & & 2 & 12 & & 1 & 1 & & 1 & 12 & & 29 \\
\hline 302 & & $\mathrm{H} 2 / \mathrm{U} 2$ & $110-120$ & & 3 & 22 & & & & & & 20 & & 45 \\
\hline 303 & 39 & $\mathrm{H} 2 / \mathrm{U} 2$ & $120-130$ & & 1 & 48 & & 1 & 1 & & 3 & 45 & & 99 \\
\hline 304 & & $\mathrm{M} 2 / \mathrm{U} 1$ & $20-50$ & & 6 & 33 & 1 & & & & 2 & 28 & & 70 \\
\hline 305 & & $\mathrm{M} 2 / \mathrm{U} 1$ & $50-60$ & & & 26 & & & & & 1 & 1 & charcoal & 28 \\
\hline 306 & & H3/G1 Ftr 12 & 42 & & & 1 & & & & & & & & 1 \\
\hline 307 & & H2/G1 Ftr 18 & 62 & & & 4 & & & & & & 3 & & 7 \\
\hline 308 & & $\mathrm{H} 2 / \mathrm{G} 1 \mathrm{Ftr} 19$ & 55 & & 1 & 2 & & & & & & 4 & & 7 \\
\hline 309 & & $\mathrm{H} 2 / \mathrm{G} 1 \mathrm{Ftr} 20$ & 61 & & 1 & 6 & & & & & & 12 & & 19 \\
\hline 310 & & $\mathrm{H} 2 / \mathrm{G} 1 \mathrm{Ftr} 21$ & 68 & & 5 & 17 & & & 1 & & 3 & 13 & & 39 \\
\hline 311 & & $\mathrm{H} 2 / \mathrm{G} 3 \mathrm{Ftr} 24$ & 24 & & & 2 & & & & & 1 & 4 & & 7 \\
\hline 312 & & $\mathrm{M} 2 / \mathrm{G} 2 \mathrm{Ftr} 26$ & 26 & & 3 & 2 & & & & & 1 & 3 & & 9 \\
\hline 313 & & L6/G4 Ftr 29 & 36 & & & & & & & 1 & & & & 1 \\
\hline 314 & & L6/G7 Ftr 32 & 50 & & & & & & & & & 1 & & 1 \\
\hline 315 & & F/G4 Ftr 44 & 55 & & & & & & & & & & tooth & 0 \\
\hline 316 & & L6/G7 & 50 & & & & & & & & & 1 & & 1 \\
\hline 317 & & $\mathrm{H} 2 / \mathrm{U} 1$ & $66-81$ & & 2 & 7 & & & & & & 4 & & 13 \\
\hline 318 & & $\mathrm{H} 2 / \mathrm{U} 1$ & $80-90$ & & 2 & 8 & & & & & 3 & 4 & & 17 \\
\hline 319 & & $\mathrm{H} 2 / \mathrm{U} 1$ & $90-100$ & & & 2 & & & & & 1 & 1 & & 4 \\
\hline 320 & & $\mathrm{H} 2 / \mathrm{U} 2$ & $130-140$ & & 3 & 25 & & & 1 & & & 32 & & 61 \\
\hline
\end{tabular}




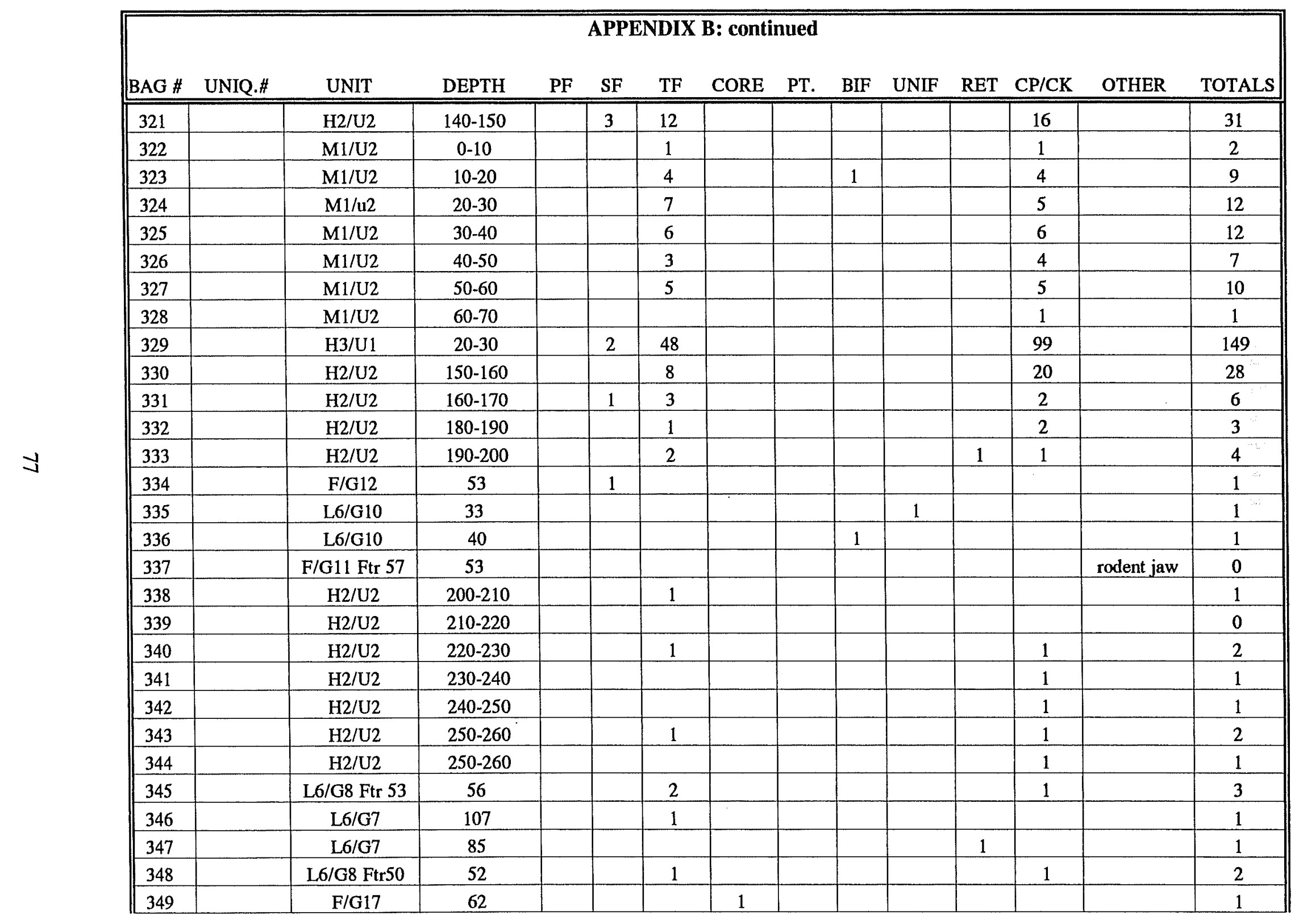




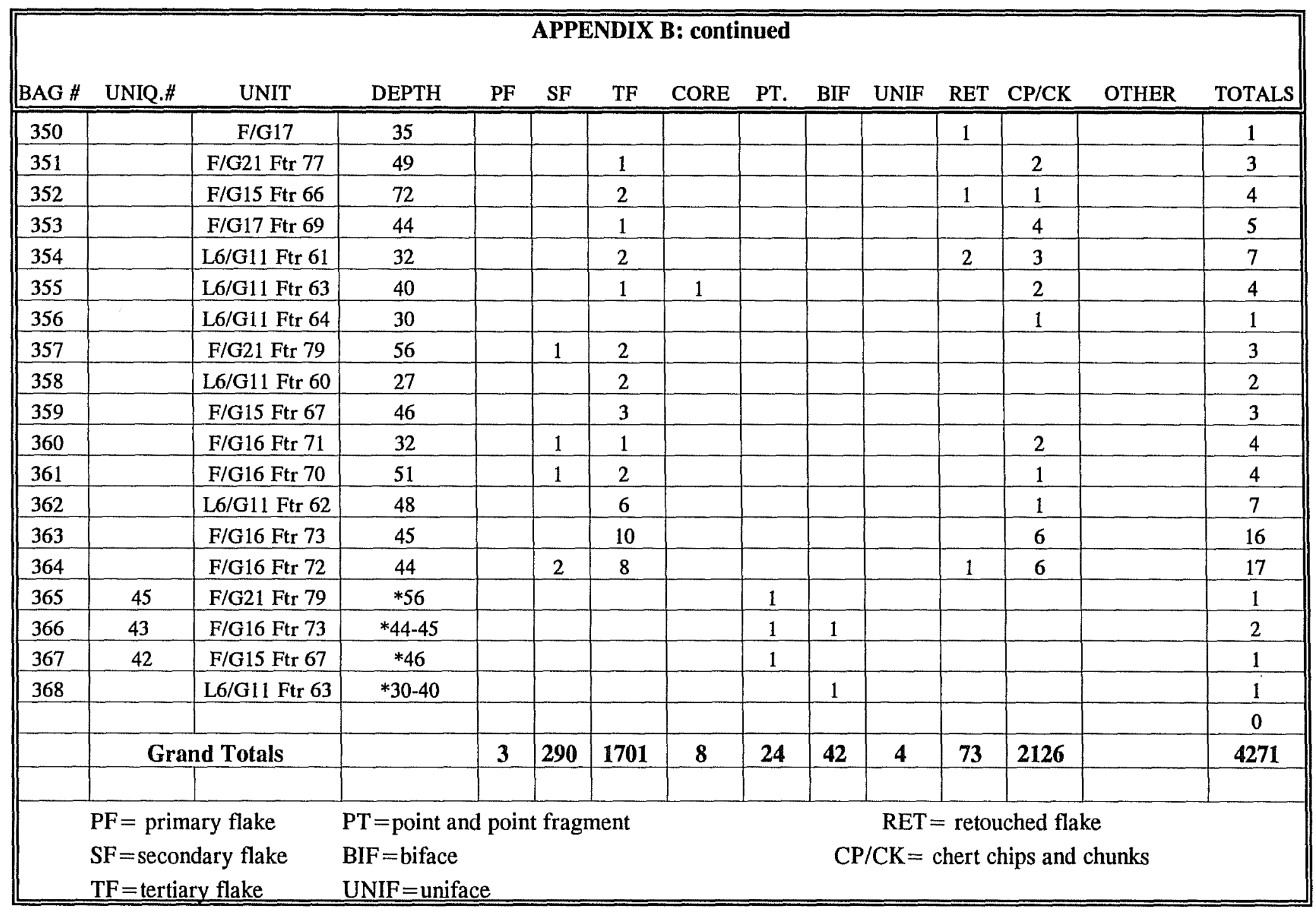




\title{
APPENDIX C: ARCHEOMAGNETISM OF FEATURE 49
}

\author{
Wulf A. Gose \\ Department of Geological Sciences \\ The University of Texas at Austin
}

Specimens from five burned rock samples were subjected to paleomagnetic analyses. Each specimen was thermally demagnetized at 200 , $300,400,450,500$, and $550^{\circ} \mathrm{C}$ and the characteristic directions of magnetization were calculated by the principal component method.

All but Specimen 5 behave in a very similar manner during demagnetization: demagnetization at $200^{\circ} \mathrm{C}$ removed a soft component and a univectorial decay towards the origin is observed during further demagnetization (Figure C-1). Specimen 5 is an order of magnitude weaker than the other samples and magnetically much softer (Figure C-2). It does contain a lowtemperature component but its characteristic direction is only poorly defined. The directions of magnetization are shown in two stereonets (Figure C-3). The magnetic components which were erased by heating to $200^{\circ} \mathrm{C}$ cluster moderately well near the expected direction (Figure C-3a). The directions of the hightemperature components are scattered but clearly not randomly (Figure C-3b).

The data indicated that the rocks, with the possible exception of rock 5 , were heated to above $550^{\circ} \mathrm{C}$. After cooling to about $200^{\circ} \mathrm{C}$, the rocks moved, perhaps due to collapse of the fire place as the fuel was used up, and remained largely undisturbed since. 

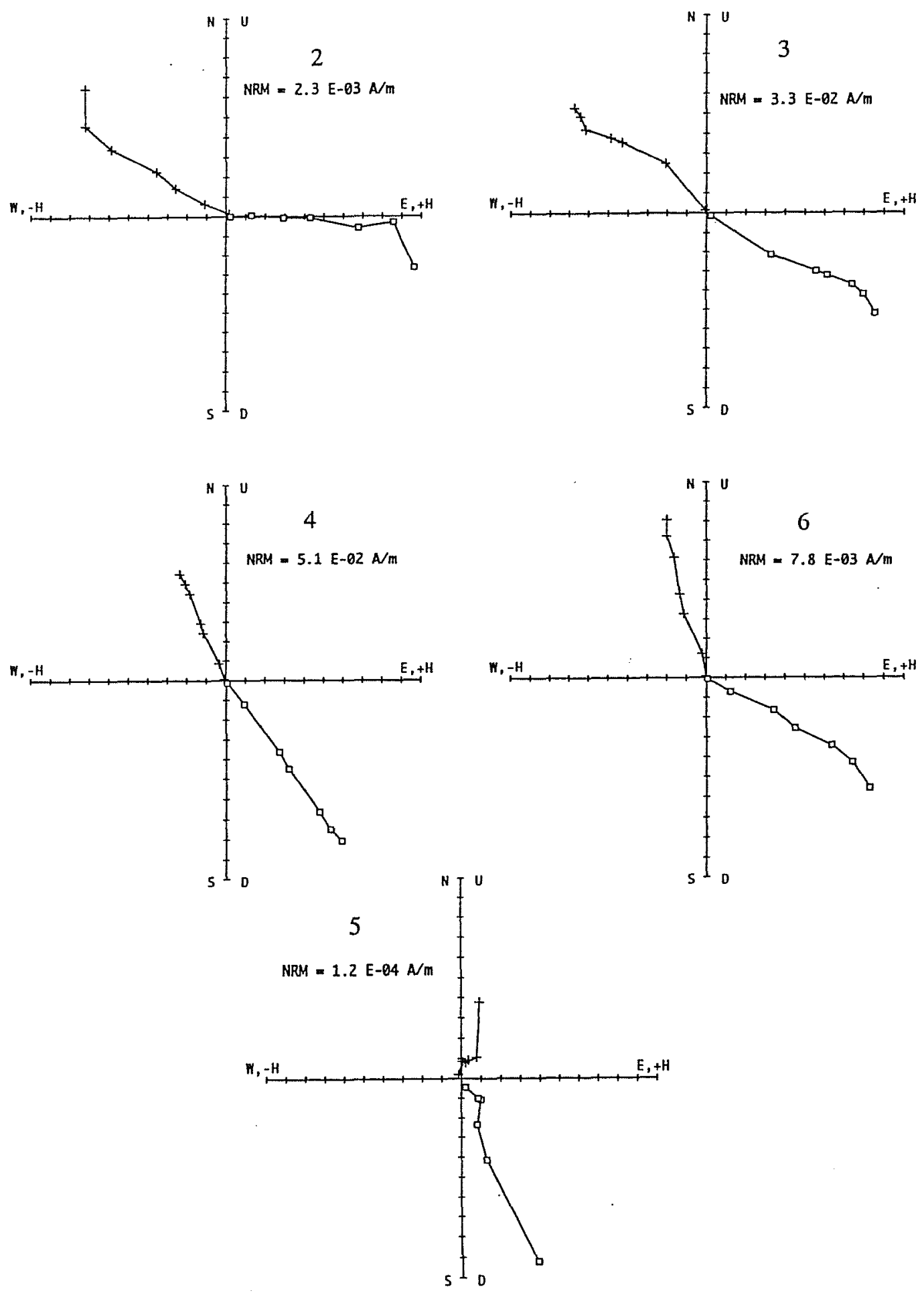

Figure C-1. Vector component diagrams for all samples from Feature 49. Open squares are the projection onto the up-down-horizontal plane, crosses are in the north-south-east-west plane. The samples were demagnetized at $200,300,400,450,500$, and $550^{\circ} \mathrm{C}$. A low-temperature component is erased by heating to $200^{\circ} \mathrm{C}$. Demagnetizing at higher temperature results in a univectorial decay towards the origin. 


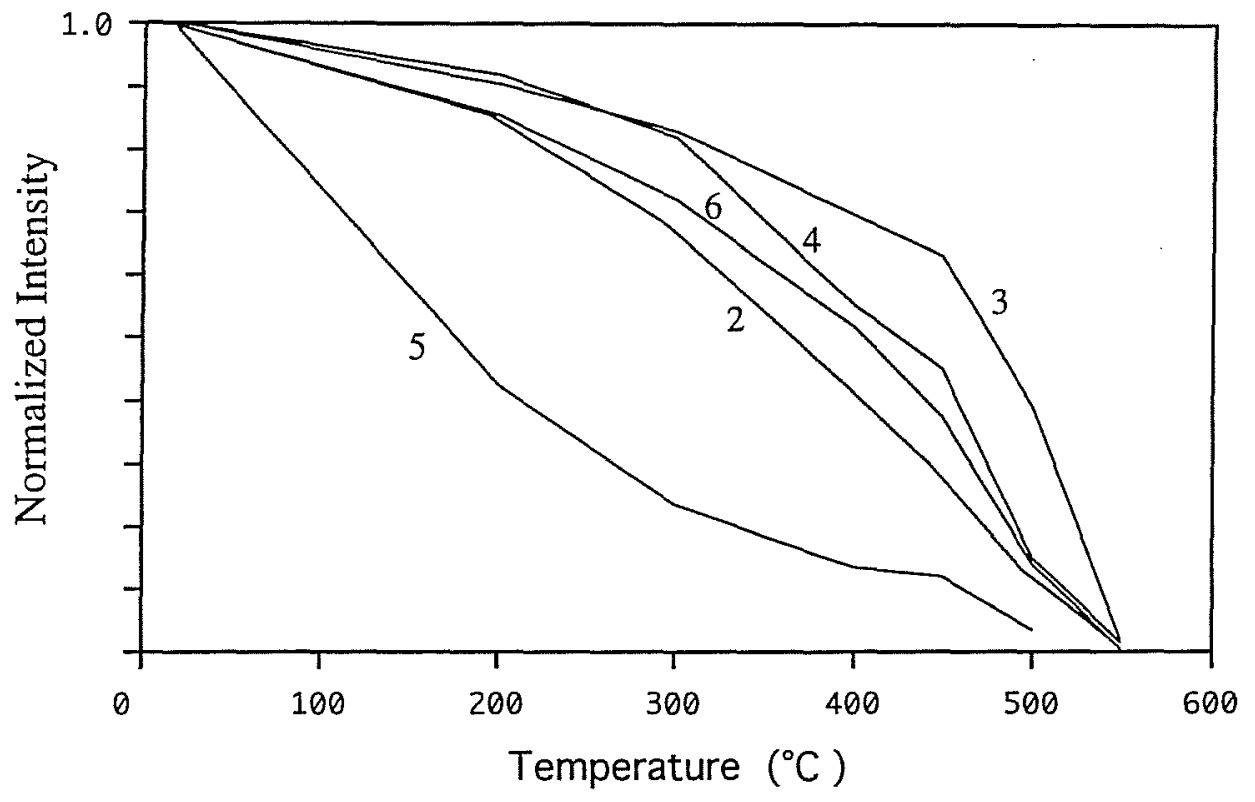

Figure C-2. Normalized intensity of magnetization as a function of temperature. Note that Sample 5 is magnetically much softer than the other samples.

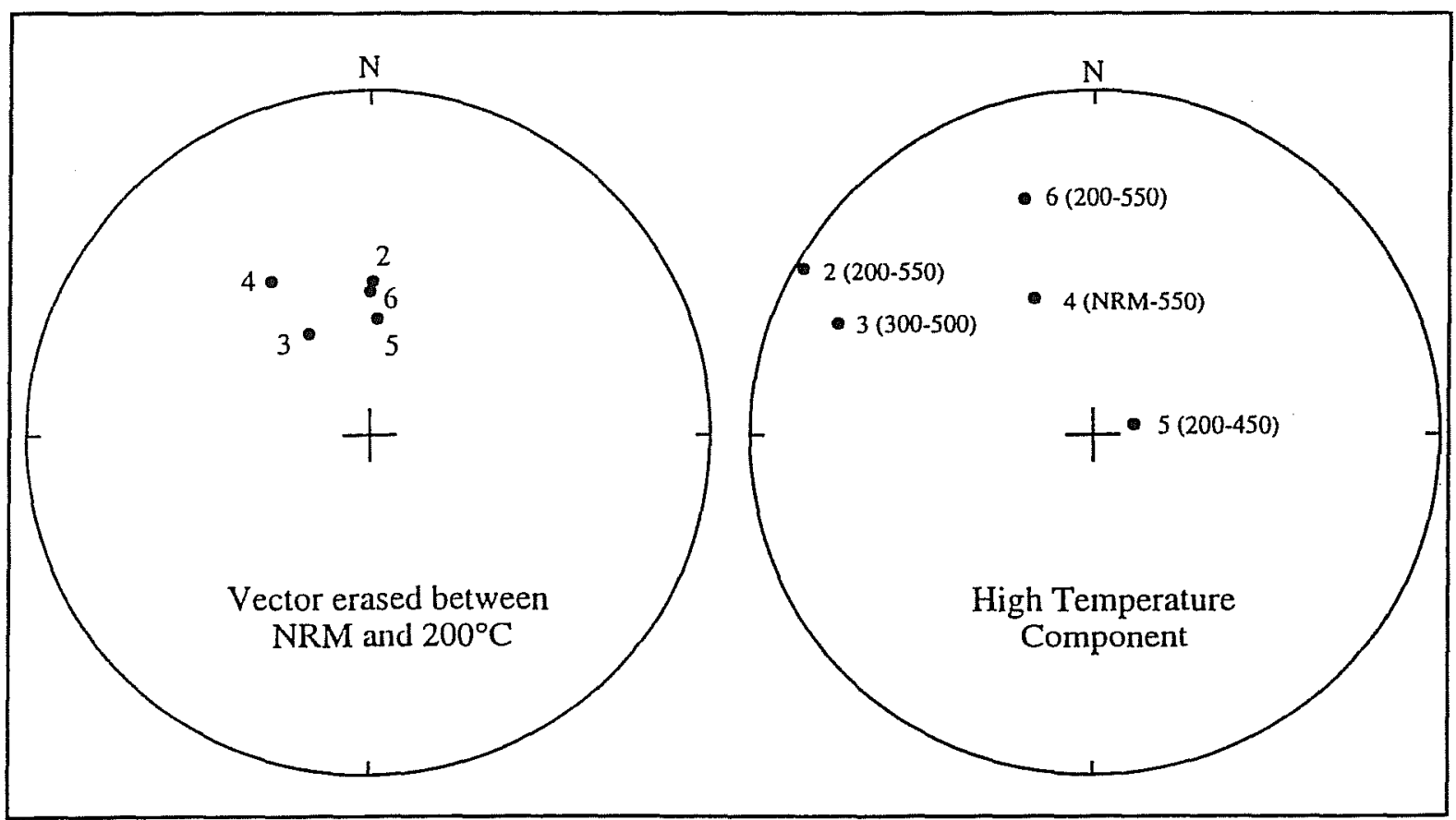

Figure C-3. Equal area stereographic projection of the directions of magnetization. The left net depicts the directions of the low-temperature components and the right net shows the directions of the hightemperature components. The numbers in parentheses indicate the temperature range over which the components were calculated. All data points are in the lower hemisphere. 
